\title{
AVALIAÇÃO MULTICRITÉRIOS, EM AMBIENTE SIG, NA DEFINIÇÃO DE ÁREAS PRIORITÁRIAS À RESTAURAÇÃO FLORESTAL VISANDO À CONSERVAÇÃO DE RECURSOS HÍDRICOS
}

\author{
Carlos Alberto Vettorazzi
}

Tese apresentada à Escola Superior de Agricultura "Luiz de Queiroz", da Universidade de São Paulo, como parte dos requisitos para obtenção do título de Livre Docente do Departamento de Engenharia Rural, na especialidadel disciplina Topografia

Piracicaba 


\section{AVALIAÇÃO MULTICRITÉRIOS, EM AMBIENTE SIG, NA DEFINIÇÃO DE ÁREAS PRIORITÁRIAS À RESTAURAÇÃO FLORESTAL VISANDO À CONSERVAÇÃO DE RECURSOS HÍDRICOS}

Carlos Alberto Vettorazzi

Engenheiro Agrônomo

Doutor em Agronomia

Tese apresentada à Escola Superior de Agricultura "Luiz de Queiroz", da Universidade de São Paulo, como parte dos requisitos para obtenção do título de Livre Docente do Departamento de Engenharia Rural, na especialidade/disciplina Topografia

Piracicaba

2006 
Dedico este trabalho aos meus queridos pais,

Odemar e Maria Luiza

(in memoriam).

À minha esposa, Lígia, e ao amor de nossas vidas, Ana Carolina, ofereço este fruto de meu (nosso) trabalho. 


\section{AGRADECIMENTOS}

Ao término de um trabalho, é importante lembrar daqueles que estiveram ao nosso lado durante a jornada, seja auxiliando, direta ou indiretamente, seja incentivando, por meio de atos, palavras, ou a simples, mas decisiva, presença. Assim, não posso deixar de prestar meus eternos agradecimentos: a Deus, pela graça da vida; à minha família; ao Prof. Dr. Rubens Angulo Filho; à Dra. Roberta de Oliveira Averna Valente; ao Dr. Silvio Frosini de Barros Ferraz; ao Prof. Dr. Décio Eugênio Cruciani; ao Prof. Dr. Antonio Sanches de Oliveira; à Sra. Vanda Macedo Zambello; e, finalmente, ao Departamento de Engenharia Rural da ESALQ/USP, na pessoa de seu atual chefe, Prof. Dr. José Antônio Frizzone, pelas condições oferecidas para a realização deste trabalho. 


\section{SUMÁRIO}

Página

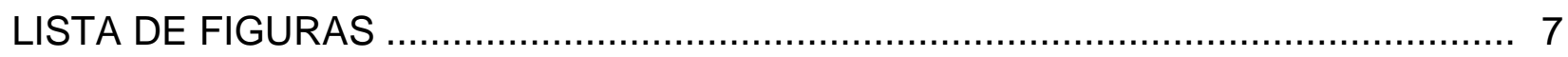

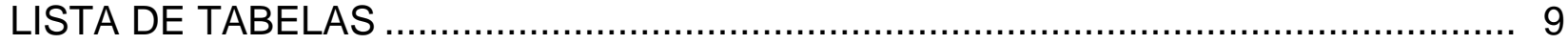

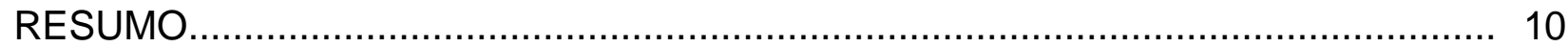

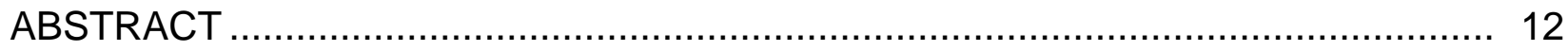

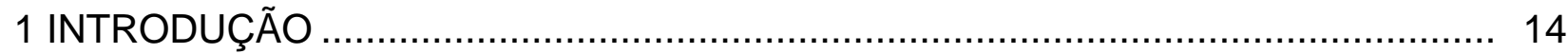

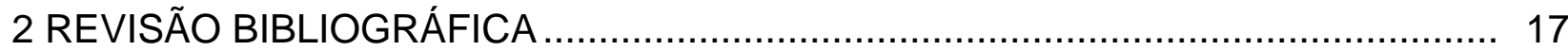

2.1 Sistemas de Informações Geográficas e análise ambiental .............................. 17

2.2 SIG e Avaliação Multicritérios...................................................................... 18

2.2.1 Integração SIG - Avaliação Multicritérios...................................................... 18

2.2.2 Métodos de Avaliação Multicritérios …..................................................... 29

2.3 SIG e definição de áreas prioritárias à conservação da água e do solo em nível

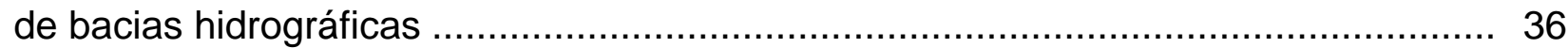

2.4 Restauração de áreas florestais ................................................................ 42

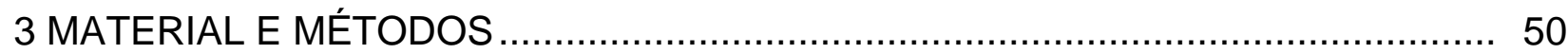

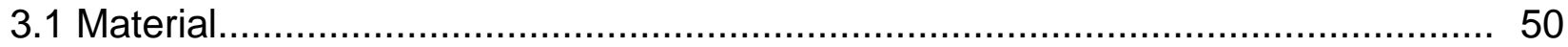

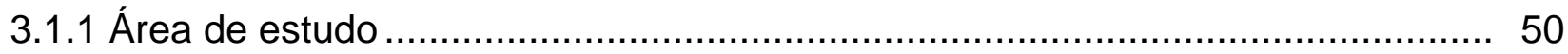

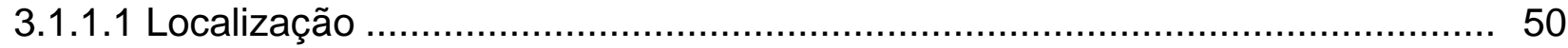

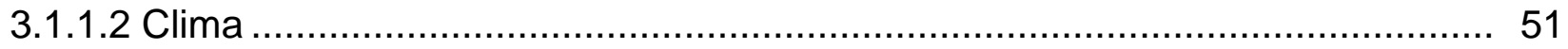

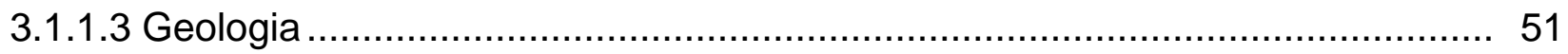

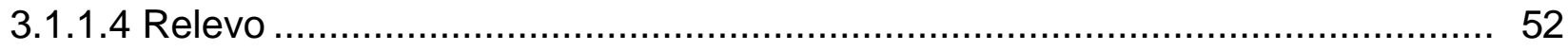

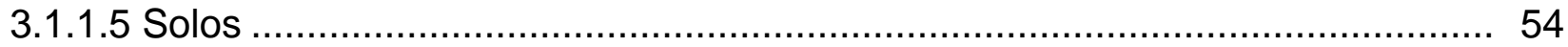

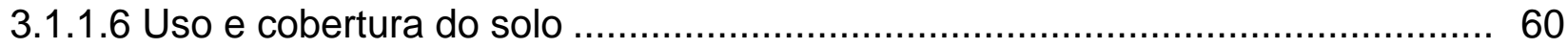

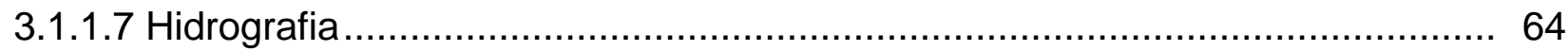

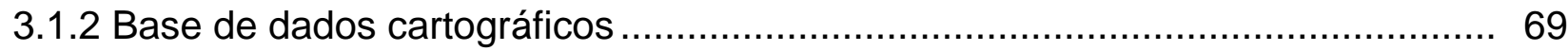

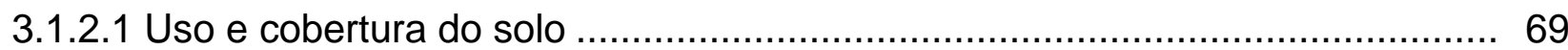

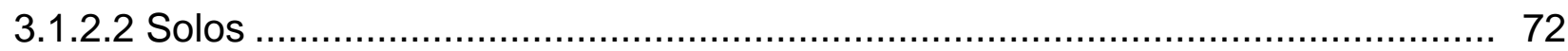

3.1.2.3 Classes de capacidade de uso da terra ................................................ 72

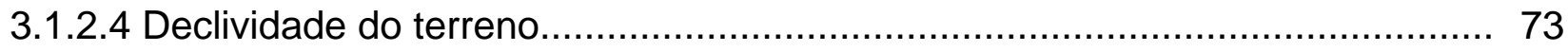




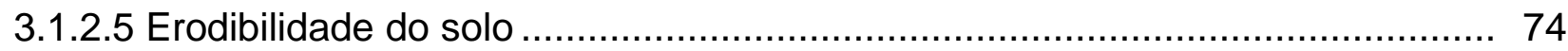

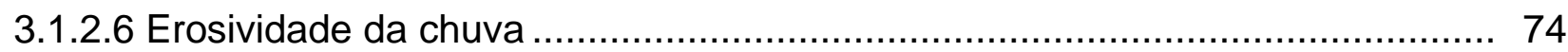

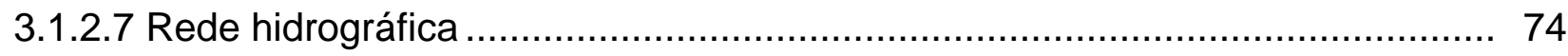

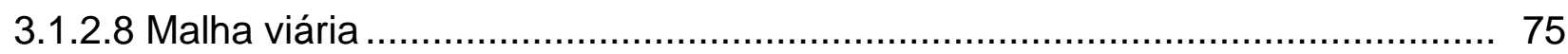

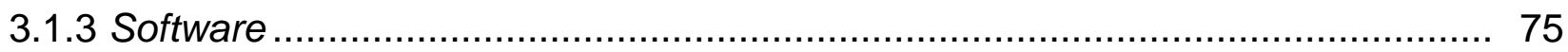

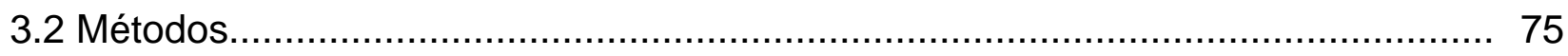

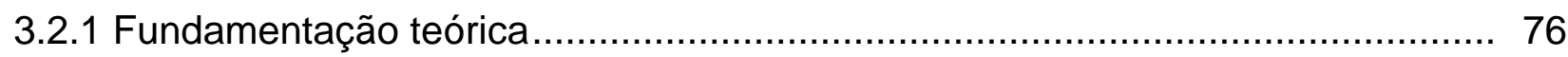

3.2.1.1 Análise estratégica de decisão .......................................................... 76

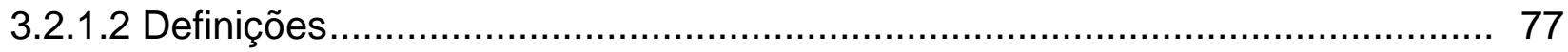

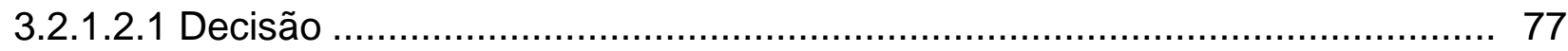

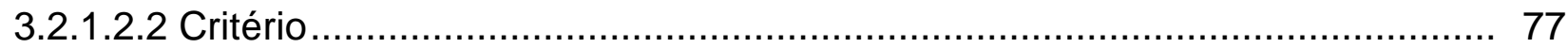

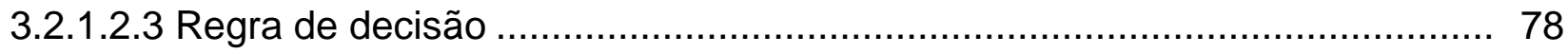

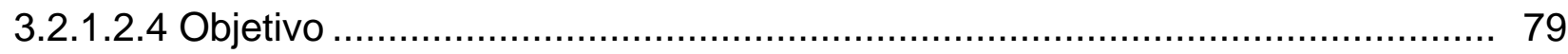

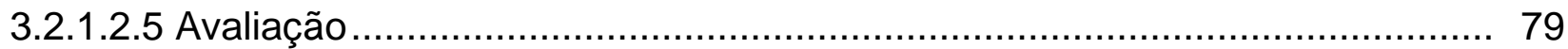

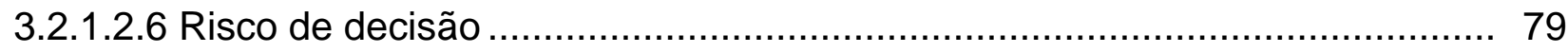

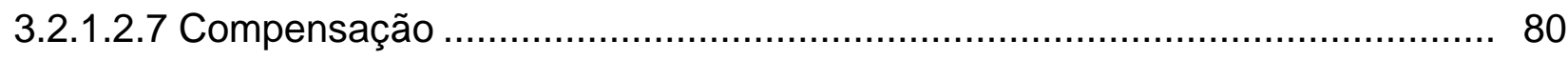

3.2.1.3 Visão geral dos métodos para análise de adequação do uso da terra

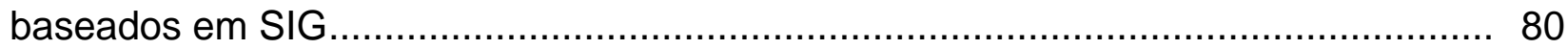

3.2.1.3.1 Sobreposição de mapas assistida por computador ................................... 80

3.2.1.3.2 Métodos de tomada de decisão multicritérios ......................................... 81

3.2.1.3.3 Métodos de inteligência artificial......................................................... 85

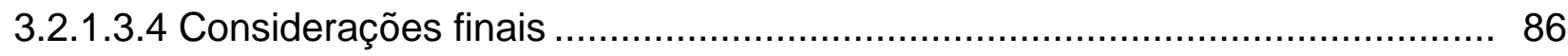

3.2.1.4 Método da Combinação Linear Ponderada ................................................ 87

3.2.1.5 Método da Média Ponderada Ordenada ..................................................... 91

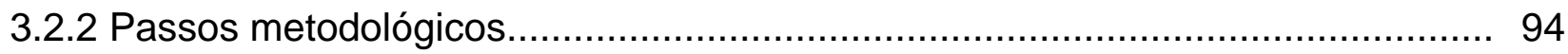

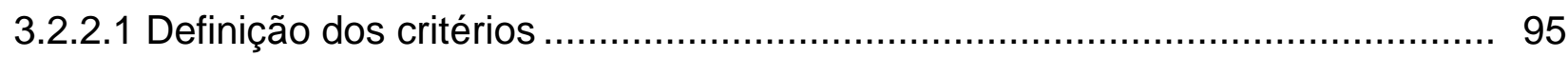

3.2.2.2 Definição dos pesos dos fatores .......................................................... 95

3.2.2.3 Seleção dos planos de informação ........................................................... 95

3.2.2.4 Geração dos mapas de fatores e de restrições ............................................ 95

3.2.2.5 Geração dos mapas de áreas prioritárias..................................................... 96

3.2.2.6 Reclassificação dos mapas de áreas prioritárias ......................................... 98 
3.2.2.7 Caracterização ambiental das áreas prioritárias ........................................ 98

3.2.2.8 Análise comparativa entre os métodos.................................................... 98

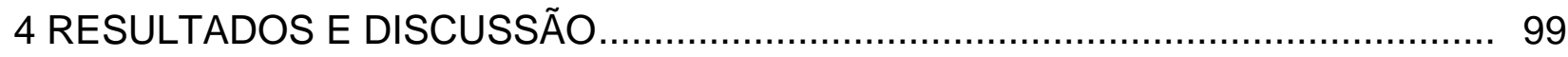

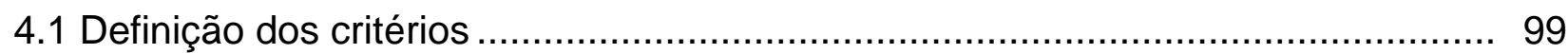

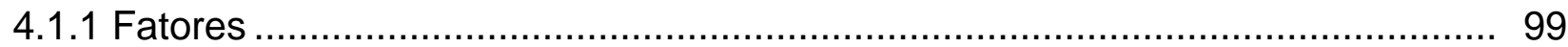

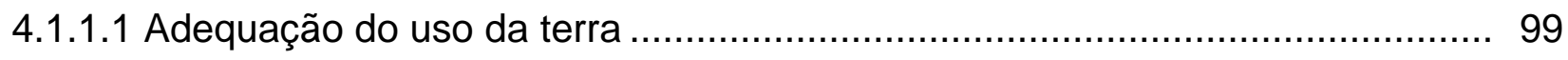

4.1.1.2 Erodibilidade do solo ...................................................................... 100

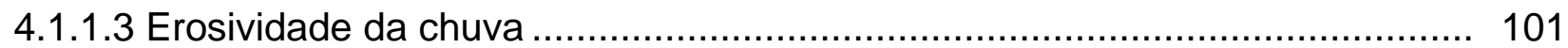

4.1.1.4 Proximidade à malha viária ................................................................... 101

4.1.1.5 Proximidade à rede hidrográfica.......................................................... 102

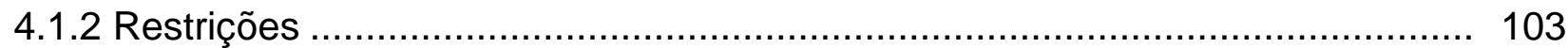

4.2 Definição dos pesos dos fatores ........................................................... 104

4.3 Seleção dos planos de informação ............................................................. 105

4.4 Geração das imagens de fatores e de restrições ............................................... 105

4.4.1 Imagens de fatores.......................................................................... 105

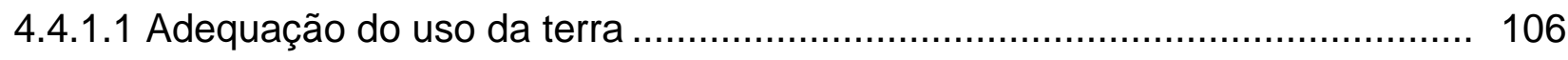

4.4.1.2 Erodibilidade do solo .................................................................... 106

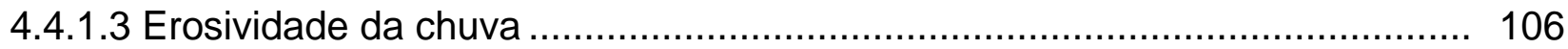

4.4.1.4 Proximidade à malha viária ............................................................. 108

4.4.1.5 Proximidade à rede hidrográfica........................................................ 108

4.4.2 Imagem de restrições ...................................................................... 108

4.5 Geração dos mapas de áreas prioritárias...................................................... 108

4.6 Análise comparativa entre os métodos ...................................................... 121

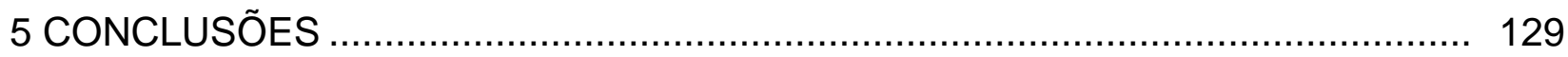

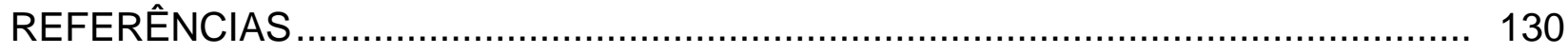




\section{LISTA DE FIGURAS}

Página

Figura 1 - Localização da área de estudo .......................................................... 50

Figura 2 - Mapa geológico da bacia do Rio Corumbataí .......................................... 53

Figura 3 - Modelo digital do terreno para a bacia do Rio Corumbataí ........................ 54

Figura 4 - Classes de solo presentes na bacia do Rio Corumbataí........................... 55

Figura 5 - Ordens de solo presentes da bacia do Rio Corumbataí, segundo o Novo Sistema de Classificação de Solos Brasileiros ........................................................ 59

Figura 6 - Uso e cobertura do solo da bacia do Rio Corumbataí em 2003.................. 63

Figura 7 - Sub-bacias que compõem a bacia do Rio Corumbataí ................................ 65

Figura 8 - Rede de drenagem da bacia do Rio Corumbataí .................................... 67

Figura 9A - Planos de informação para a bacia do Rio Corumbataí, empregados na Avaliação Multicritérios: (a) uso e cobertura do solo; (b) solos; (c) classes de capacidade de uso da terra; e (d) classes de declividade.

Figura 9B - Planos de informação para a bacia do Rio Corumbataí, empregados na Avaliação Multicritérios: (e) erodibilidade do solo; (f) erosividade da chuva;(g) rede hidrográfica; e (h) malha viária

Figura 10 - Escala contínua de nove pontos usada na comparação pareada entre fatores, na Avaliação Multicritérios

Figura 11 - Espaço de decisão estratégica no método da Média Ponderada Ordenada

Figura 12 - Fluxograma das etapas desenvolvidas no presente trabalho

Figura 13 - Fatores e restrições da Avaliação Multicritérios: (a) adequação do uso da terra; (b) erodibilidade do solo; (c) erosividade da chuva; (d) proximidade à malha viária; (e) proximidade à rede hidrográfica; e (f) restrições. 
Figura 14 - Áreas prioritárias à restauração florestal geradas pelo método da Combinação Linear Ponderada (escala contínua de prioridades) ........................... 109

Figura 15 - Áreas prioritárias à restauração florestal geradas pelo método da Média Ponderada Ordenada, risco médio/baixo (escala contínua de prioridades) ...

Figura 16 - Áreas prioritárias à restauração florestal geradas pelo método da Média Ponderada Ordenada, risco médio/alto (escala contínua de prioridades) .......

Figura 17 - Áreas prioritárias à restauração florestal geradas pelo método da Combinação Linear Ponderada (cinco níveis de prioridade)....

Figura 18 - Áreas prioritárias à restauração florestal geradas pelo método da Média Ponderada Ordenada, risco médio/baixo (cinco níveis de prioridade)

Figura 19 - Áreas prioritárias à restauração florestal geradas pelo método da Média Ponderada Ordenada, risco médio/alto (cinco níveis de prioridade)

Figura 20 - Distribuição espacial das áreas de prioridade muito alta para restauração florestal, na bacia do Rio Corumbataí, geradas pelo método da Combinação Linear Ponderada, com detalhe ampliado

Figura 21 - Distribuição espacial das áreas de prioridade muito alta para restauração florestal, na bacia do Rio Corumbataí, geradas pelo método da Média Ponderada Ordenada, risco médio/baixo, com detalhe ampliado

Figura 22 - Distribuição espacial das áreas de prioridade muito alta para restauração florestal, na bacia do Rio Corumbataí, geradas pelo método da Média Ponderada Ordenada, risco médio/alto, com detalhe ampliado

Figura 23 - Assoreamento em curso d'água, em área de pastagens na região do Alto Corumbataí 


\section{LISTA DE TABELAS}

Página

Tabela 1 - Classes de solo presentes na bacia do Rio Corumbataí........................... 56

Tabela 2 - Uso e cobertura do solo da bacia do Rio Corumbataí em 2003 ................. 64

Tabela 3 - Matriz de comparação pareada entre os fatores definidos para a Avaliação Multicritérios.

Tabela 4 - Pesos de ordenação para os fatores utilizados na Avaliação Multicritérios, pelo Método da Média Ponderada Ordenada

Tabela 5 - Valores de área para os cinco níveis de prioridade obtidos pela aplicação do método da Combinação Linear Ponderada.

Tabela 6 - Valores de área para os cinco níveis de prioridade obtidos pela aplicação do método da Média Ponderada Ordenada, risco médio/baixo

Tabela 7 - Valores de área para os cinco níveis de prioridade obtidos pela aplicação do método da Média Ponderada Ordenada, risco médio/alto

Tabela 8 - Caracterização ambiental das áreas com graus de prioridade alto e muito alto, obtidas pelo método da Combinação Linear Ponderada

Tabela 9 - Caracterização ambiental das áreas com graus de prioridade alto e muito alto, obtidas pelo método da Média Ponderada Ordenada, risco médio/baixo.

Tabela 10 - Caracterização ambiental das áreas com graus de prioridade alto e muito alto, obtidas pelo método da Média Ponderada Ordenada, risco médio/alto....

Tabela 11 - Caracterização geral das áreas classificadas como de prioridades alta e muito alta, para restauração florestal, geradas pelo método da Média Ponderada Ordenada, risco médio/baixo 


\section{RESUMO}

\section{Avaliação Multicritérios, em ambiente SIG, na definição de áreas prioritárias à}

\section{restauração florestal visando à conservação de recursos hídricos}

O reflorestamento em bacias hidrográficas, notadamente por meio da restauração florestal, tem sido apontado como uma das soluções mais factíveis e baratas para a questão da produção de água de boa qualidade para o uso humano. Ações conservacionistas são estratégicas para a redução do custo de tratamento da água. Contudo, mesmo sendo uma solução das mais baratas, a restauração apresenta, de maneira geral, um custo ainda elevado, exigindo um planejamento que aponte áreas prioritárias para o investimento de recursos, em geral muito limitados, em reflorestamento. Diferentes abordagens podem ser empregadas na determinação dessas áreas prioritárias, como o uso de modelos hidrológicos, índices de produção de sedimentos etc., mas a necessidade da representação da distribuição espacial das áreas a serem restauradas torna imprescindível o uso dos Sistemas de Informações Geográficas, dada a sua capacidade de análise de dados de natureza espacial. Nos últimos anos, diversos métodos para a determinação de áreas prioritárias têm sido desenvolvidos para operar em ambiente SIG, destacando-se aqueles que têm por base a análise de múltiplos critérios. A diferença entre os diversos métodos está na forma de agregação dos critérios, principalmente no que se refere à maneira com que tratam de questões como a probabilidade de sucesso, ou risco, do empreendimento, e também a possibilidade de compensação entre as importâncias relativas dos fatores. Assim, este estudo teve como objetivo avaliar o emprego da Avaliação Multicritérios, em ambiente SIG, por meio da comparação entre os métodos da Combinação Linear Ponderada e da Média Ponderada Ordenada, na geração de mapas de áreas prioritárias à restauração florestal, na bacia do Rio Corumbataí, SP, visando à conservação de recursos hídricos. Os fatores empregados foram a adequação do uso da terra, a erodibilidade do solo, a erosividade da chuva e as proximidades à malha viária e à rede hidrográfica, todos representados como mapas matriciais, em que cada fator foi padronizado a uma escala única e contínua de 256 valores. Os pesos dos fatores foram determinados com auxílio de uma matriz de comparação pareada. A agregação dos fatores foi realizada em um SIG matricial, por meio dos dois métodos sob avaliação. No caso do método da Média Ponderada Ordenada foram estudados dois cenários diferentes, em relação aos níveis de risco e de compensação entre fatores. Os resultados obtidos foram mapas de áreas prioritárias, com graus de prioridade representados de forma contínua no espaço de 256 níveis. Para facilitar a visualização e também a análise dos resultados gerados pelos três cenários, os mapas foram reclassificados, de maneira a apresentar apenas cinco graus de prioridade. A partir dos resultados obtidos foi possível concluir que a Avaliação Multicritérios, em ambiente SIG, é adequada ao mapeamento de áreas prioritárias à restauração florestal, visando à conservação de recursos hídricos, e que o método da Média Ponderada Ordenada é o mais adequado à priorização de áreas, dada a sua flexibilidade, ao acomodar o conceito de compensação entre fatores. Essa 
característica permite um mapeamento mais detalhado das áreas prioritárias, que são menores e em maior número que no outro método.

Palavras-chave: Áreas prioritárias; Restauração florestal; Sistema de Informações Geográficas; Avaliação Multicritérios; Combinação Linear Ponderada; Média Ponderada Ordenada; Bacia do Rio Corumbataí 


\begin{abstract}
Multicriteria Evaluation, in a GIS environment, in the definition of priority areas for forest restoration aiming at the conservation of water resources
\end{abstract}

Reforestation in river basins, mainly through forest restoration, has been pointed out as one of the most feasible and cheapest solutions for the issue of good-quality water production for human consumption. Conservation actions are strategic for the reduction of the cost of water treatment. Nevertheless, even forest restoration being one of the cheapest solutions, it presents a relatively high cost, needing a plan to point out priority areas for the investment, of limited financial resources, in reforestation. Different approaches can be employed in the determination of those areas, like the use of hydrologic models, sediment yield indices etc., but the need of representation of the spatial distribution of the areas to be restored makes the use of Geographic Information Systems indispensable, due to their ability of spatial data analysis. In the last years, several methods for the determination of priority areas, running in GIS, have been developed, standing out those based on multicriteria analysis. The difference among the methods resides in the way they aggregate the criteria, mainly regarding the manner they deal with issues such as risk and trade-off. Thus, this study had the objective to analyze the Multicriteria Evaluation, in a GIS environment, through the comparison between the methods of Weighted Linear Combination and Ordered Weighted Averaging, in the generation of maps of priority areas for forest restoration, in the Corumbataí river basin, State of São Paulo, aiming at the conservation of water resources. The factors used were the land-use adequacy, soil erodibility, erosivity, proximity to roads and proximity to the drainage network, all of them represented by raster maps, where each factor was standardized to a 256-value continuous scale. The factor weights were determined with the help of a pairwise comparison matrix. Factors aggregation was performed in a raster-based GIS, with the methods under evaluation. In the case of the Ordered Weighted Averaging, two different scenarios, regarding the levels of risk and trade-off among factors, were studied. The results obtained were maps of priority areas, with levels of priority represented on a continuous way, from 0 to 255 . In order to make it easy the visualization and also the analysis of the results generated by the three scenarios, the maps were re-classified, to show only five levels of priority, from very low through very high. From the results obtained it was possible to conclude that the Multicriteria Evaluation, in a GIS environment, fits well to the mapping of priority areas for forest restoration, aiming at the conservation of water resources, and that the method of Ordered Weighted Averaging is the more adequate to the prioritization of areas, due to its flexibility, accommodating the concept of trade-off among factors. Such characteristic allows a more detailed mapping of the priority areas, which results smaller and more numerous than the ones generated by the Weighted Linear Combination. 
Keywords: Priority areas; Forest restoration; Geographic Information System; Multicriteria Evaluation; Weighted Linear Combination; Ordered Weighted Averaging; Corumbataí River Basin 


\section{INTRODUÇÃO}

Dos recursos naturais terrestres, a água é um dos que vêm sofrendo as maiores pressões na atualidade. Sendo um bem indispensável à vida, a água possui valor inestimável. Além da questão da potabilidade, a água também é fundamental ao funcionamento dos ecossistemas e estratégica aos setores de saúde pública, geração de energia, transporte, lazer e produção industrial e agrícola. Em resumo, a água é essencial à qualidade de vida, não sendo possível pensar em desenvolvimento sustentável sem uma oferta adequada à população de água de boa qualidade.

A água doce disponível ao consumo humano possui uma distribuição marcadamente irregular no planeta e, hoje, vêm se tornando comuns tanto a classificação das nações em ricas ou pobres em água, como as polêmicas alusões a uma provável necessidade de compartilhamento internacional desse recurso.

O Brasil, a despeito de ser detentor de uma fração significativa da água doce disponível no mundo, também é marcado pela sua distribuição irregular, com pouco mais de $10 \%$ das águas superficiais nas regiões mais densamente povoadas, onde se concentram mais de $90 \%$ da demanda hídrica do país. Com isso, algumas regiões já sofrem de escassez de água, de ordem quantitativa e/ou qualitativa. Essa escassez é produto, em geral, dos efeitos de aumentos localizados da demanda, bem como da crescente degradação dos recursos hídricos.

A reversão dessa situação não é tarefa fácil, nem tampouco barata, necessitando de ações, em geral integradas, que envolvem a construção de obras civis, planejamento do uso e cobertura do solo, racionalização do uso da água etc.

Uma das maiores ameaças à qualidade da água, tanto superficial como subterrânea, é a poluição difusa, resultante principalmente do uso agrícola inadequado dos solos. A substituição da cobertura original do solo por culturas agrícolas, aliada a práticas de manejo inadequadas, altera, entre outras coisas, as relações entre escoamento superficial e infiltração da água das chuvas, resultando em erosão do solo e carreamento de quantidades acima do normal de sedimentos aos canais de drenagem. Esse fenômeno é responsável pela aceleração do processo de assoreamento dos canais, além de alterar as características físicas e químicas da água 
pela presença dos sedimentos, material orgânico, nutrientes e outros elementos e compostos químicos, provenientes principalmente de defensivos agrícolas e fertilizantes, encarecendo os processos de captação e tratamento da água para consumo humano.

A supressão de áreas florestais e a sua substituição por outras coberturas podem contribuir de forma significativa para os processos de geração, transporte e deposição de sedimentos nos canais de drenagem. As florestas de encosta protegem a superfície do solo do início do processo erosivo, promovem a infiltração da água no solo e funcionam como barreiras ao transporte dos sedimentos. Ao redor das nascentes elas têm importante função de proteção, principalmente contra a compactação e o assoreamento, por práticas agrícolas inadequadas. Ao lado dos canais, as florestas ripárias, também chamadas de ciliares, quando com largura e estrutura adequadas, podem funcionar como filtros dos sedimentos, material orgânico e elementos químicos e compostos associados, promovendo sua deposição antes de atingirem os cursos d'água, além de protegerem diretamente os canais contra a erosão de suas margens e contribuírem para aumentar a capacidade de armazenamento de água na bacia.

Assim, depreende-se que a oferta natural de água, em quantidade e qualidade adequadas, depende, entre outros fatores, de um planejamento adequado do uso e cobertura do solo. O reflorestamento dirigido em bacias hidrográficas, notadamente por meio de ações de restauração florestal, tem sido apontado como uma das soluções mais factíveis e baratas para a questão da produção de água de boa qualidade para o uso humano. Ações conservacionistas são estratégicas para a redução do custo de tratamento da água. O problema é que, mesmo sendo uma solução das mais baratas, a restauração apresenta, ainda assim, um custo elevado, exigindo um planejamento cuidadoso que aponte áreas prioritárias para o investimento de recursos em reflorestamento.

Existem diferentes abordagens interessantes de ser utilizadas na determinação dessas áreas prioritárias, como o emprego de modelos hidrológicos, índices de produção de sedimentos etc., mas, de qualquer forma, a exigência da explicitação da distribuição espacial das áreas a serem restauradas torna imprescindível, nessa tarefa, 
o uso dos Sistemas de Informações Geográficas (SIGs), dada a sua capacidade de análise de dados de natureza espacial.

Nos últimos anos, diversos sistemas de apoio à decisão, apropriados à determinação, para uma ou mais finalidades, de áreas prioritárias, de risco, adequadas etc., têm sido desenvolvidos ou adaptados para operar em ambiente SIG, destacandose aqueles que têm por base a avaliação de múltiplos critérios, como os métodos da Análise Booleana, da Combinação Linear Ponderada e da Média Ponderada Ordenada, este último de introdução mais recente.

A despeito do certo grau de subjetividade que envolve a seleção dos critérios e, principalmente, o julgamento da importância relativa entre eles, que se traduz em pesos quantitativos na análise, os resultados obtidos por meio dessa abordagem, em várias áreas de aplicação, têm sido bastante animadores, devido à coerência com a realidade observada.

A diferença entre os diversos métodos está na forma de agregação dos critérios, principalmente no que se refere à maneira como que tratam de questões como a probabilidade de sucesso, ou risco, do empreendimento, e também a possibilidade de compensação entre as importâncias relativas dos fatores, no processo de tomada de decisão.

Neste contexto, foi formulada a hipótese de que áreas indicadas para restauração florestal, em diferentes graus de prioridade, podem ser mapeadas por meio de sistemas de apoio à decisão, em um Sistema de Informações Geográficas, com maior ou menor sucesso, em função do grau de flexibilidade oferecido pelo método ao analista, no que se refere à forma de agregação dos critérios.

Para testar a hipótese de trabalho, este estudo teve como objetivo avaliar o emprego da Avaliação Multicritérios, em ambiente SIG, especificamente por meio da comparação entre os métodos da Combinação Linear Ponderada e da Média Ponderada Ordenada, na geração de mapas de áreas prioritárias à restauração florestal, na bacia do Rio Corumbataí, SP, visando à conservação de recursos hídricos. 


\section{REVISÃO BIBLIOGRÁFICA}

\subsection{Sistemas de Informações Geográficas e análise ambiental}

Sistemas de Informações Geográficas (SIGs) são sistemas bastante apropriados à análise ambiental, devido às suas características relacionadas à questão da espacialização da análise. Nas últimas décadas, a análise ambiental recebeu um impulso bastante grande com o desenvolvimento dos SIGs. Das atividades mais beneficiadas podem ser citadas os zoneamentos (VERÍSSIMO et al., 1998), os mapeamentos de risco (TEMESGEN; MOHAMMED; KORME, 2001), de vulnerabilidade (MENNELLA et al., 1996; BRYAN et al., 2001); de sensibilidade (LAPLANA; BRUNSTEIN, 1992; CLAYTON, 1994; ABDEL-KADER et al., 1998); de impactos ambientais (MOE et al., 2000) etc. Um passo adiante nessas atividades é a determinação de prioridades, para a qual o SIG também pode ser empregado, dadas as suas capacidades analíticas.

Costuma-se dizer que, atualmente, em se tratando de SIG, as possibilidades de análise são limitadas somente pela imaginação dos analistas e pela disponibilidade de dados adequados (DAHL; YOUNG; CALDWELL, 1996). As análises em ambiente SIG, havendo dados e instrumentos adequados, podem ocorrer desde níveis mais abrangentes, isto é, grandes áreas (BOJORQUEZTAPIA et al., 1995), até os mais detalhados, como os de microbacias hidrográficas e propriedades rurais (HILL et al., 1996).

As áreas de aplicação são as mais diversificadas possíveis, podendo ser citadas: risco e prevenção de incêndios florestais (MCKINSEY, 1988; JAIN et al., 1996); planejamento de uso da terra (BEHRE, 1992; NIGHMAN; ARNOLD; McKEW, 1999; STOORVOGEL; ANTLE, 2001); seleção de áreas apropriadas à construção de pequenas barragens (PADMAVATHY et al., 1993); manejo florestal (GREEN et al., 1993; VERÍSSIMO et al., 1998; OSTWALD, 2002); seleção de áreas prioritárias à conservação (BOJORQUEZTAPIA et al., 1995; SMITH; HORNING; MOORE, 1997; RAMESH; MENON; BAWA, 1997; WRIGHT; TANIMOTO, 1998; LATHROP JR.; BOGNAR, 1998; ROY; TOMAR, 2000; HOCTOR; CARR; ZWICK, 2000; VERÍSSIMO et 
al., 2002); gerenciamento de recursos hídricos (ROOY; SLUIS; TOLKAMP, 1995); planejamento de áreas verdes urbanas (VILLA; CERONI; MAZZA, 1996); mapeamento de áreas potenciais quanto à desertificação (AHARONI; WARD, 1997); zoneamentos agrícolas (PANIGRAHY; CHAKRABORTY, 1998); determinação de áreas prioritárias ao controle de doenças (ROBINSON, 1998; HENDRICKX et al., 2001); gerenciamento pesqueiro (WEBB; BACON, 1999; HAWKS; STANOVICK; CALDWELL, 2000); estudos faunísticos (JARVIS; ROBERTSON, 1999; BRITO et al., 1999; BORRALHO; STOATE; ARAUJO, 2000; LURTZ et al., 2003); avaliação de habitats (PEREIRA; DUCKSTEIN, 1993; O'BRIEN-WHITE; THOMASON, 1999; NIEMUTH, 2003) etc.

\subsection{SIG e Avaliação Multicritérios}

\subsubsection{Integração SIG - Avaliação Multicritérios}

Em muitas das aplicações de SIG na área de análise ambiental, é comum o envolvimento de múltiplos critérios para se atender a um ou mais objetivos. É a denominada Avaliação Multicritérios (AMC).

Embora a técnica de AMC possa ser empregada fora do ambiente SIG, e a literatura contém inúmeros exemplos dessa situação (TURNER et al., 2000; DAVOS; LAJANO, 2001; YIN, 2001; DALGAARD; HALBERG; PORTER, 2001; ANDERTON; LATRON; GALLART, 2002; AFGAN; CARVALHO, 2002; MAZZETTO; BONERA, 2003; ESPELTA; RETANA; HABROUK, 2003; para citar alguns), é na integração com o SIG que seu potencial é melhor explorado, em se tratando de análises espaciais.

Malczewski (2004) afirma que a integração entre as técnicas de tomada de decisão multicritérios e sistemas de informações geográficas representa um avanço considerável nas análises envolvendo adequação de uso da terra, em relação às abordagens convencionais de sobreposição (overlay) de mapas. Segundo o autor, a AMC em ambiente SIG pode ser pensada como um processo que combina e transforma dados espaciais e não-espaciais (entrada) em uma decisão resultante (saída). Os procedimentos envolvem a utilização de dados geográficos, as preferências dos tomadores de decisão e a manipulação dos dados e preferências de acordo com regras 
de decisão especificadas. Desta maneira, duas considerações são de importância crítica para a AMC: (1) as capacidades do SIG de aquisição, armazenamento, recuperação, manipulação e análise de dados; e (2) as capacidades dos métodos de tomada de decisão multicritérios (TDMC) em combinar os dados geográficos e as preferências dos tomadores de decisão em valores unidimensionais de decisões alternativas.

Jankowski (1995) cita que o processo de tomada de decisão, envolvendo prioridades políticas, compensações (trade-offs) e incertezas, pode ser auxiliado por métodos de TDMC. O autor apresenta um quadro geral para a integração entre SIG e métodos de TDMC. Nesse quadro geral os métodos são classificados e combinados com heurísticas de escolha usadas por tomadores de decisão, na presença de alternativas competindo entre si, e avaliação multicritérios. A primeira estratégia sugere juntar SIG e técnicas de TDMC usando um mecanismo de permuta de arquivos (file exchange). A segunda estratégia sugere a integração entre SIG e funções de TDMC usando-se uma base de dados comum.

Eastman et al. (1995) afirmam que decisões sobre a alocação de terra tipicamente envolvem a avaliação de múltiplos critérios, de acordo com diversos, e em geral conflitantes, objetivos. Para os autores, o advento do SIG proporcionou a oportunidade de execução de processos de tomada de decisão, na área ambiental, de forma mais explicitamente racional. Entretanto, ainda segundo os autores, a área de SIG tem sido lenta para desenvolver instrumentos de apoio à decisão, dependendo de procedimentos desenvolvidos fora do software de SIG.

Segundo Zhou e Civco (1996), as abordagens tradicionais para análise de adequação de terras em SIG são a sobreposição de planos de informação (overlay) e, a mais elaborada, AMC. Os autores comentam que, a despeito de serem amplamente usados, esses métodos têm, pelo menos, três problemas: (1) dificuldades em lidar com dados espaciais com problemas de exatidão, múltiplas escalas de medição e dependência de fatores; (2) necessidade de conhecimento prévio para identificar critérios, definir pesos (relação de importância entre os fatores), determinar preferências para critérios e selecionar funções de agregação; e (3) interfaces tipicamente nãoamigáveis com o usuário. Buscando solucionar esses problemas, os autores 
apresentam uma abordagem envolvendo redes neurais. A rede neural usa um algoritmo genético como mecanismo de aprendizado. Um conjunto de experimentos revelou que as dificuldades mencionadas anteriormente podem ser vencidas com o uso das redes neurais, que podem ser consideradas como uma alternativa aos métodos tradicionais de análise de adequação em SIG.

Malczewski (1996) e Malczewski e Jackson (2000) comentam que o problema de tomada de decisão multicritérios envolve um conjunto de planos alternativos de alocação, avaliados com base em critérios múltiplos, conflitantes e incomensuráveis, por grupos de indivíduos com interesses diversos. Esses grupos são caracterizados por preferências específicas, com respeito às importâncias relativas dos critérios, contra o que os planos alternativos são avaliados. De grande importância para os problemas de tomada de decisão no setor público é a busca de consenso entre as várias partes interessadas. Os autores sugerem que a AMC pode ser usada com sucesso no desenvolvimento de projetos alternativos de alocação, facilitando o compromisso entre interesses conflitantes. Nesse aspecto, uma variedade de abordagens desenvolvidas nos últimos 20 anos, junto a um crescente interesse em análises realizadas em SIGs, deverá levar a uma grande ênfase em procedimentos alternativos de busca e conceitos de sistemas computacionais interativos de apoio à decisão.

Para Pettit e Pullar (1999), a despeito da adoção generalizada do SIG em administrações locais, para o mapeamento cadastral e gerenciamento de bens, o potencial integral do SIG ainda não tem sido empregado. O SIG é usado pelos planejadores principalmente para o gerenciamento de dados e busca de registros relacionados à terra. O planejamento mais avançado não tem tirado vantagem da capacidade de análise espacial dos SIGs. Com base em uma pesquisa entre usuários, os autores identificaram a causa do problema da disparidade entre o modo com que os planejadores resolvem seus problemas e o ambiente operacional de um SIG. Isto é, quando os pesquisadores olham para as tarefas que precisam desempenhar para resolver um problema, eles têm dificuldades em relacioná-las às operações executáveis em um SIG. Os autores propõem, então, uma solução que envolve a integração entre um procedimento rigoroso de tomada de decisão e análise espacial e a apresenta através de uma interface projetada especificamente para planejadores. A abordagem 
da teoria de decisão é baseada na Avaliação Multicritérios (AMC). A análise espacial é usada para definir os fatores do projeto e no processo de avaliação, para agregar fatores na solução final.

Jankowski; Andrienko e Andrienko (2001) discutem o papel dos mapas em avaliações multicritérios. Segundo os autores, o apoio à decisão espacial é uma das funções centrais de um SIG. Um dos focos no desenvolvimento de capacidades de apoio à decisão em ambiente SIG tem sido a integração de mapas com modelos de decisão multicritérios. Ainda de acordo com os autores, o progresso nessa área tem sido lento, devido ao papel limitado desempenhado pelos mapas como instrumentos de apoio à decisão. Assim, apresentam um protótipo de instrumentos de apoio à decisão espacial, enfatizando o papel dos mapas como uma fonte de estrutura em problemas de decisão espacial multicritérios. Nesses instrumentos, o papel dos mapas vai além da mera exibição do espaço geográfico de decisão e de resultados da AMC. Os mapas tornam-se um "índice visual" pelo qual o usuário ordena opções de decisão, assinala prioridades a critérios de decisão e aumenta o espaço de saída (outcome) dos critérios pelo conhecimento derivado dos mapas.

Em ambiente SIG, a AMC, por meio de diversas abordagens, como a Booleana, a Combinação Linear Ponderada (CLP) e a Média Ponderada Ordenada (MPO), tem sido empregada nas mais variadas aplicações, como apresentado a seguir.

Em estudos envolvendo erosão do solo podem ser citados os trabalhos de Laplana e Brunstein (1992) e de Dragan et al. (2003). Laplana e Brunstein (1992) empregaram a AMC na preparação de mapas de sensibilidade às erosões hídrica e eólica, como instrumentos de gerenciamento para uso no campo, na Floresta de Landes de Gascogne, França. Após o estabelecimento de um registro das restrições espaciais presentes, os mecanismos de ocorrência dos citados fenômenos foram estudados para evidenciar, por um lado, aqueles fatores explicativos dos processos e, por outro lado, a informação geográfica necessária à análise espacial. A organização dos dados em planos de informação sucessivos, em um SIG, possibilitou a implementação de técnicas de análise espacial. Essa análise inicial, complementada por um estudo de agregação multicritérios, resultou na definição de uma escala de 
níveis de sensibilidade, permitindo a visualização da distribuição espacial dos riscos potenciais de erosão.

Dragan et al. (2003) aplicaram um sistema espacial de apoio à decisão (SEAD), com base em análise de decisão multicritérios e multiobjetivos, em um estudo de caso na Etiópia, visando à redução de erosão do solo por meio da realocação de culturas agrícolas de acordo com sua capacidade de proteger o solo. O SEAD foi implementado usando o SIG Idrisi 32.2, com o envolvimento direto de atores locais na definição de fatores e restrições, relacionados ao uso e cobertura do solo, altitude, potencial de erosão, proximidade a estradas, água e a capacidade relativa de cada cultura agrícola em proteger o solo. Uma redução na perda de solo de uma média de 4,5 Mg.ha ${ }^{-1}$.ano ${ }^{-1}$ a valores abaixo do limite de risco de degradação do solo (1 Mg.ha ${ }^{-1}$.ano ${ }^{-1}$ ) poderia ser atingida por meio da aplicação dos resultados do SEAD. O maior impedimento ao exercício de realocação foi, entretanto, a carência de terras cultiváveis disponíveis.

Pereira e Duckstein (1993), Frutuoso; Vettorazzi e Couto (1999) e Store e Kangas (2001) podem ser citados como exemplos de aplicação de AMC-SIG na avaliação de habitats. Pereira e Duckstein (1993) utilizaram uma combinação de técnicas de tomada de decisão multicritérios, incluindo técnicas de avaliação de valor e de prioridade, para avaliar a adequação da terra em um SIG matricial (raster). Como estudo de caso apresentaram a avaliação de habitat para uma espécie de esquilo.

Frutuoso; Vettorazzi e Couto (1999) mapearam a probabilidade de ocorrência do veado-campeiro (Ozotoceros bezoarticus), na época seca, em seu habitat natural, no Parque Nacional das Emas (PNE), em Goiás, por meio de AMC em ambiente SIG. Na elaboração do mapa de probabilidade (qualitativa) de ocorrência da espécie foram considerados fatores ambientais naturais e antrópicos, bem como informações provenientes de observações de campo e da bibliografia existente sobre biologia e comportamento da espécie. Esses dados foram integrados em um SIG (Idrisi for Windows 2.0), adotando-se o procedimento de tomada de decisão por meio da avaliação multicritérios/único objetivo. O mapa final foi reclassificado em três regiões diferenciadas em termos de probabilidade de ocorrência da espécie (maior, média e menor), que foram verificadas por meio da sobreposição de dados georreferenciados de visualização aérea do veado-campeiro na área de estudo. A análise estatística dos 
dados mostrou haver diferença significativa entre os tratamentos (faixas de probabilidade de ocorrência), comprovando a eficiência da metodologia empregada.

Store e Kangas (2001) empregaram a AMC em ambiente SIG na modelagem da adequação de habitats. Para melhorar a avaliação da adequação em grandes áreas foram usados, no estudo, o processamento de dados e análise espacial em SIG, juntamente com técnicas de análise de decisão. Podem ser aplicados nessa abordagem tanto os modelos de avaliação empíricos como aqueles baseados em conhecimento especialista. Os requerimentos em habitat das espécies foram descritos como planos de informação (na forma de mapas) no SIG, de tal maneira que cada mapa representasse um critério. O SIG foi usado como plataforma no gerenciamento, combinação e exibição de dados de critério e também como um instrumento para a geração de novos dados, especialmente pelo uso das funções de análise espacial. A padronização, a ponderação e a combinação de critérios foram realizadas por meio de métodos de AMC. Usando-se funções de prioridade contínua e de sub-prioridade na avaliação, não foi necessária a classificação de atributos contínuos e também puderam ser consideradas relações não-lineares entre adequação de habitat e atributos. Foi aplicada uma análise de sensibilidade para considerar o fator temporal na AMC e para verificar o efeito de diferentes pesos para os critérios sobre o padrão espacial do índice de adequação. Alterando-se os pesos dos fatores permanentes e dos variáveis com o tempo, alterou-se a localização dos habitats ótimos para as espécies. Os autores concluíram que, a longo prazo, fatores permanentes, tais como as propriedades dos solos, definem o potencial do habitat, que é importante ser levado em consideração, como por exemplo no planejamento do manejo florestal, tendo em vista a conservação de espécies.

Na área agrícola, Li e Yeh (2001) empregaram a AMC em ambiente SIG para o zoneamento de terras. Os autores comentam que o zoneamento de terras agrícolas, para fim de proteção, tem se tornado uma atividade estratégica na redução da perda de áreas com alto potencial agrícola em regiões de rápido desenvolvimento. Os fatores de adequação e a geometria das áreas agrícolas foram incorporados ao modelo, para facilitar a alocação racional de terras para proteção. O modelo foi implementado em um 
SIG, que proporcionou informações úteis sobre restrições, além de um ambiente adequado para modelagem.

A AMC também pode ser empregada, com sucesso, no mapeamento de áreas apropriadas ao plantio de culturas agrícolas. Ceballos-Silva e Lopez-Blanco (2003a) utilizaram a abordagem AMC, em ambiente SIG, para identificar áreas adequadas ao plantio de aveia (Avena sativa L.) no México Central. Foram considerados fatores ambientais relevantes, tais como clima, solo e relevo, em diferentes resoluções espaciais e temporais. Para a geração dos mapas de fatores padronizados foi usada a função de pertinência fuzzy. Os resultados indicaram que as variáveis mais importantes para o desenvolvimento da cultura da aveia foram a precipitação, a altitude e a profundidade do solo. Também identificaram 6.663 ha com um nível alto de adequação, que representavam 57\% mais que o território então usado para o cultivo não-irrigado da aveia no México Central.

Ainda na mesma linha, Ceballos-Silva e Lopez-Blanco (2003b) aplicaram a AMC na identificação de áreas adequadas à produção de milho e de batata no México. Foram usadas bases de dados de relevo, solo e clima para compor os planos de informação em um SIG (Idrisi). Foram então definidos os critérios relevantes para 0 desenvolvimento das culturas, bem como os níveis de adequação. Essa informação foi usada para a obtenção dos mapas de critérios que, por sua vez, foram usados como entrada no algoritmo de AMC. Diversos procedimentos de apoio à decisão no ambiente Idrisi foram aplicados para se obter o mapa de adequação para cada cultura. Uma imagem TM/Landsat foi processada, por meio de classificação supervisionada, para se obter o mapa de uso e cobertura do solo. Os mapas de uso e cobertura e de adequação foram então cruzados, identificando-se diferenças e similaridades entre 0 uso atual e as áreas mapeadas como adequadas para o cultivo do milho e da batata.

De maneira análoga, Gumbricht; McCarthy e Mahlander (1996) empregaram a abordagem AMC-SIG, na área florestal, para a determinação de áreas adequadas ao reflorestamento com duas espécies de Pinus, no Chipre.

Wang e Medley (2004) também se valeram da tecnologia SIG para desenvolver um modelo baseado em múltiplos critérios, visando à identificação de áreas apropriadas à restauração florestal, em Ohio, EUA, com relação ao seu potencial para conservação 
de carbono. Os critérios relacionaram-se principalmente às condições do solo e do relevo, favoráveis ao desenvolvimento de florestas. O estudo apresentou um recurso valioso para planejamento ecológico, que prioriza áreas para conservação florestal com base em suas contribuições funcionais para o balanço regional de carbono.

Ainda nessa linha conservacionista, Ferraz e Vettorazzi (2003) utilizaram a AMC para a identificação de áreas apropriadas à recomposição florestal, com espécies nativas, em fazendas de reflorestamento, com base em princípios de ecologia da paisagem. Foram estabelecidos cinco critérios para determinação de áreas para recomposição: fertilidade do solo; presença de mata nativa; corpos d'água; declividade do terreno; e suscetibilidade do solo à erosão. Esses fatores foram analisados empregando-se o recurso de tomada de decisão multicritérios em um SIG. Como resultado foi obtido um mapa das áreas adequadas à recomposição florestal, segundo os critérios adotados. Com esse mapa realizou-se uma simulação, alocando-se uma nova área de floresta nativa no local estudado e o resultado foi avaliado em nível de paisagem, por meio de índices apropriados.

Merwe e Lohrentz (2001) empregaram a AMC e SIG para demarcar faixas de vegetação, na África do Sul, na zona costeira de Saldanha-Langebaan. Como em qualquer lugar no mundo, existe nessa região, segundo os autores, uma necessidade aguda de se balancear desenvolvimento e crescimento econômico com conservação ambiental. O conceito de faixas de vegetação tem sido usado com sucesso em tais esforços de conservação. Ele foi aplicado na área de estudo, por meio de um SIG como plataforma para um sistema de apoio à decisão, para legitimizar a demarcação de uma zona (faixa) vegetada. O método de AMC, como aplicado pelos autores, incorporou a tomada de decisão pública na construção de um modelo com o objetivo de demarcação de uma faixa de vegetação. Representantes das partes interessadas participaram da construção e calibração do modelo, resultando na delimitação espacial de uma faixa vegetada multifuncional, de acordo com vários critérios.

Varma; Ferguson e Wild (2000) discutiram o componente metodológico de um sistema de apoio à decisão para o manejo florestal sustentável, em nível de unidade de manejo. Os autores desenvolveram uma técnica de AMC baseada em um SIG para medir a sustentabilidade do manejo florestal, integrando dados espaciais e temporais 
sobre diversas variáveis ecológicas, econômicas e sociais, levando em conta também as incertezas na base de dados e na regra de decisão. Os autores propuseram uma abordagem de apoio à decisão usando o conceito de funções de utilidade baseadas em aspiração, para formular estratégias para aumentar a sustentabilidade florestal, combinando programação linear e SIG. Assim, o trabalho tenta preencher a lacuna entre o esforço considerável de pesquisa feito no desenvolvimento de um quadro geral para medir a sustentabilidade do manejo florestal e a falta de esforços similares no monitoramento e uso desses indicadores como uma parte formal do sistema de planejamento.

Para Kangas et al. (2000), as análises ecológicas da paisagem e sua integração com a análise multiobjetivos de planos florestais podem ser melhoradas pelo apoio de métodos, técnicas e instrumentos de apoio à decisão, produzidos por pesquisas recentes em planejamento florestal. Nesse trabalho é dada atenção especial ao fortalecimento de estudo de cálculos ecológicos, por meio de modelagens, quantificação de avaliações ecológicas, integração de diferentes objetivos em diferentes fases do processo de planejamento e análise de efeitos da incerteza em julgamentos ecológicos. A abordagem ecológica da paisagem vem encontrando, de acordo com os autores, uma aplicação crescente no planejamento florestal prático. Infelizmente, ainda segundo os autores, lacunas no conhecimento ecológico disponível e a ineficiência de métodos e instrumentos de planejamento usados, freqüentemente levam a processos de planejamento falhos. Em muitos casos, apenas métodos originalmente desenvolvidos para planejamento silvicultural são ainda aplicados e avanços no planejamento, como por exemplo a otimização multiobjetivos, técnicas de SIG e modelagem, são sub-utilizados.

Ainda na área florestal, a abordagem AMC-SIG tem sido utilizada com sucesso no mapeamento de áreas de risco de incêndios, como exemplificado nos trabalhos de Ferraz e Vettorazzi (1998) e Chen e Blong (2003).

Ferraz e Vettorazzi (1998) desenvolveram uma metodologia para o mapeamento de risco de incêndios em áreas florestais, por meio de um SIG. A área de estudo foi a Estação Experimental de Tupi (EET), do Instituto Florestal do Estado de São Paulo, no município de Piracicaba. A partir de mapas, fotografias aéreas e informações de campo, 
foram obtidos os elementos para a geração, no software Idrisi, de cinco planos de informação, referentes aos critérios empregados na análise: uso da terra no interior da área de estudo, declividade e face de exposição do terreno, uso da terra na vizinhança e vias de acesso. Os planos foram integrados, gerando o Mapa Base de Risco. Multiplicando-se o Mapa Base pelo Índice de Monte Alegre, introduziu-se a componente meteorológica no estudo, obtendo-se mapas de risco para situações distintas ao longo do ano. A avaliação dos resultados foi feita por meio de trabalho de campo e entrevistas com técnicos da EET, anotando-se áreas já afetadas por incêndios. Observou-se a coincidência entre focos de incêndio ocorridos e áreas de alto risco identificadas pelo estudo. Os autores concluíram que a utilização dessa metodologia pode ser útil para auxiliar as ações de prevenção a incêndios, devendo, contudo, ser realizadas adaptações nos critérios empregados, de acordo com as particularidades de cada área de interesse.

Chen e Blong (2003) desenvolveram uma abordagem integrada, com base em SIG, para a avaliação de risco em acidentes naturais, com referência a incêndios florestais. Segundo os autores, os desafios para se empregar essa abordagem apresentam três componentes: integração de dados, avaliação de riscos e tomada de decisões. Primeiramente, a integração de dados em um SIG é um passo fundamental para tarefas subseqüentes de avaliação de risco e de tomadas de decisão. Foram discutidas várias questões relativas à integração de dados em SIG, tais como escalas geográficas e modelos de dados. Particularmente, a integração entre variáveis do ambiente físico e dados sócio-econômicos foi examinada, com um exemplo da integração entre dados obtidos por sensoriamento remoto e dados censitários. Em segundo lugar devem ser realizadas tarefas específicas de avaliação de riscos, tais como simulação de comportamento de eventos e avaliação de vulnerabilidade, para permitir a compreensão da complexidade do risco e fornecer suporte à tomada de decisão. Para a avaliação de riscos envolvendo fontes heterogêneas de dados, é importante a seleção de unidades de análise espacial. Em terceiro lugar, a tomada de decisão envolve preferências espaciais e/ou padrões. Assim, os autores apresentam uma abordagem AMC-SIG para tomadas de decisão que incorpora três perspectivas: tipos de dados espaciais, modelos de dados e desenvolvimento de métodos. Foram 
identificados métodos convencionais e baseados em inteligência artificial, em SIG, para facilitar a tomada de decisões de uma maneira racional e interpretável. Finalmente, os autores concluíram que a abordagem integrada pode ser usada para auxiliar no gerenciamento de risco de desastres naturais, na teoria e na prática.

$\mathrm{Na}$ área de proteção de recursos hídricos deve ser citado o interessante trabalho de Randhir et al. (2001). Segundo os autores, o manejo da qualidade da água na escala de bacia hidrográfica é importante para a proteção do abastecimento de água. Custos crescentes de tratamento da água, junto com a necessidade de soluções cooperativas entre os vários usuários em uma bacia, reforçam a necessidade de tal abordagem. Em nível de bacia hidrográfica, benefícios ótimos de qualidade da água podem ser obtidos concentrando-se práticas nas áreas com o máximo valor marginal de proteção de qualidade da água. Para se obter isso, é essencial um programa de priorização baseado em benefícios e custos marginais. A informação, que é crucial para o desenvolvimento de um método eficiente de priorização, inclui informação geográfica, relação entre critérios e efeitos e tempo de circulação da água de runoff (escoamento superficial). Nesse trabalho foi desenvolvido um modelo de priorização em nível de microbacia hidrográfica, integrando esses três tipos de informação, que foi aplicado à microbacia do Rio Ware, em Massachusetts, EUA. Segundo os autores, ajustando-se critérios e pesos, essa abordagem pode ser adaptada para priorizar uma grande variedade de decisões relativas ao uso da terra como, por exemplo, a preservação de áreas florestais, a proteção de habitats críticos para a vida silvestre, planejamento de áreas recreacionais e planejamento ecológico-econômico.

Existe ainda, na literatura científica, uma série de trabalhos envolvendo a Avaliação Multicritérios em ambiente SIG, nas mais variadas áreas de aplicação, como, por exemplo: seleção de áreas apropriadas à implantação de aterros sanitários (CHARNPRATHEEP; ZHOU; GARNER, 1997; CALIJURI; MELLO; LORENTZ, 2002; e KONTOS; KOMILIS; HALVADAKIS, 2003); planejamento urbano (FENG; XU, 1999; LI; YEH, 2002; e GOMES; LINS, 2002); impactos ambientes causados por redes viárias (KLUNGBOONKRONG; TAYLOR, 1998); projetos viários (SADEK; BEDRAN; KAYSI, 1999; PANOU; SOFIANOS, 2002a e 2002b); recuperação de áreas degradadas por mineração (HICKEY; JANKOWSKI, 1997); identificação de áreas apropriadas à 
implantação de reservas naturais para pesquisas científicas (STOMS; McDONALD; DAVIS, 2002); e identificação de locais apropriados à criação de ostras (BUITRAGO et al., 2005).

\subsubsection{Métodos de Avaliação Multicritérios}

Segundo Malczewski (2004), ao longo da última década, ou pouco mais, vários métodos de Avaliação Multicritérios (AMC) têm sido implementados em ambiente SIG, incluindo o método Booleano, a Combinação Linear Ponderada (CLP) e suas variantes, o Método do Ponto Ideal, a Análise de Concordância e o Processo Hierárquico Analítico. Desses procedimentos, o autor cita que a CLP e o método Booleano são considerados os mais diretos e mais freqüentemente empregados. Nesta revisão, dado o objetivo da pesquisa, serão abordados apenas trabalhos relacionados aos métodos da Combinação Linear Ponderada e da Média Ponderada Ordenada, este último uma extensão da CLP que vem sendo considerada muito promissora na área ambiental, dada a flexibilidade que oferece ao processo de tomada de decisões.

O método da CLP é, de acordo com Malczewski (2000), uma das regras de decisão implementadas em ambiente SIG mais amplamente utilizadas. O método é freqüentemente aplicado a análises de adequação do uso do solo a finalidades diversas, a seleção e priorização de áreas e a problemas de avaliação de recursos.

Ainda de acordo com Malczewski (2000), a principal razão de sua popularidade é que o método é de fácil implementação em SIGs, usando-se operações de álgebra de mapas e modelagem cartográfica. O método é também considerado de fácil entendimento e intuitivo para tomadores de decisão. O autor comenta ainda que as implementações da CLP em SIGs são, entretanto, freqüentemente usadas sem o completo entendimento das suposições que fundamentam essa abordagem, duas delas críticas e relacionadas aos pesos assinalados aos atributos (critérios) e aos procedimentos para derivar mapas de atributos comensuráveis.

A seguir serão apresentados exemplos de trabalhos desenvolvidos em algumas áreas de aplicação, empregando a abordagem CLP-SIG. 
Vettorazzi, Valente e Ballester (2000) citam que algumas metodologias têm sido propostas para mapear risco de incêndios florestais em ambiente SIG. Entre essas metodologias encontra-se a Avaliação Multicritérios/Único Objetivo, que foi utilizada pelos autores nesse trabalho, tendo como área de estudo a bacia do Rio Corumbataí, SP. Os planos de informação empregados foram: uso e cobertura do solo; rede hidrográfica; estradas; declividade; e face de exposição do terreno. Esses planos foram usados para gerar os mapas de fatores. Para a definição dos fatores e de seus pesos relativos foi empregada a Técnica Participatória. Esse procedimento permitiu a geração de uma matriz de comparação pareada e do peso para cada fator. O mapa de risco de incêndios foi gerado pela agregação dos fatores por meio do método da CLP. O risco final foi reclassificado em três níveis: baixo, médio e alto. $O$ uso da terra foi o fator com maior influência sobre os resultados. Nas regiões classificadas como de alto risco, o uso da terra predominante foi a plantação de cana-de-açúcar, enquanto que nas áreas classificadas como de risco médio houve predomínio das pastagens.

Chen; Blong e Jacobson (2001) comentam que, nas duas últimas décadas, tem ocorrido um crescimento notável em trabalhos envolvendo tomada de decisão por meio da abordagem AMC-SIG. Entretanto, segundo os autores, um número limitado de trabalhos relata o desenvolvimento de softwares de AMC-SIG e a comparação entre as diferentes abordagens disponíveis. Os autores apresentam um sistema denominado MCE-RISK (Multiple Criteria Evaluation-Risk) para tomadas de decisão baseadas em risco. Ele consiste de uma série de módulos para padronização dos dados, atribuição de pesos, métodos de AMC-SIG e análise de sensibilidade. O programa incorpora diferentes métodos de AMC-SIG, incluindo a Combinação Linear Ponderada (CLP), a Técnica de Ordenamento de Preferência por Similaridade à Solução Ideal (TOPSIS) e Programação por Comprometimento (Compromise Programming), permitindo comparações entre diferentes métodos para o mesmo problema de decisão. Nesse trabalho é examinado um exemplo de tomada de decisão para a determinação de áreas prioritárias para a redução do risco de incêndios florestais. Após a implementação dos diferentes métodos de AMC-SIG e a comparação dos resultados finais e dificuldades computacionais envolvidas nas análises, foi recomendado o método da CLP. 
Dai; Lee e Zhang (2001) citam que a avaliação ambiental para planejamento de uso e ocupação do solo, em áreas urbanas, geralmente requer uma grande quantidade de informação de natureza espacial. SIGs são capazes de gerenciar grandes quantidades de informação espacial, proporcionando a capacidade de integração de múltiplos planos de informação e derivando informações adicionais. A ajuda do SIG na avaliação ambiental para planejamento do uso do solo urbano é ilustrada para a cidade de Lanzhou e vizinhança, na China. Essa avaliação incorporou dados de relevo, geologia, água subterrânea e um histórico de desastres geológicos. O uso do solo foi categorizado de acordo com o uso previamente planejado para a cidade, como construções de muitos andares, construções baixas, áreas para disposição de resíduos e para conservação. Uma análise por múltiplos critérios foi executada para se avaliar a adequação ambiental ao desenvolvimento para cada categoria, de acordo com fatores apropriadamente determinados e ponderados. Foi gerado um mapa de adequação para cada categoria usando-se um algoritmo de CLP. Os resultados demonstraram que a abordagem empregada (CLP-SIG) apresentou alta funcionalidade para avaliações ambientais.

Basnet; Apan e Raine (2001) apresentam um método para a seleção de locais para a aplicação segura dos resíduos animais como fertilizantes agrícolas. Segundo os autores, o rápido crescimento da pecuária industrial intensiva no sudoeste de Queensland, Austrália, tem levado à produção de um grande volume de resíduos animais, com sérias conseqüências ambientais para a bacia hidrográfica de Murray Darling (BMD). Foi criado um mapa de adequação de locais para a sub-bacia de Westbrook, na BMD, usando um modelo de CLP em ambiente SIG. Foram determinados os fatores que afetam a adequação de um local para a aplicação de resíduos animais e adquiridos conjuntos de dados digitais derivados de mapas em escalas de até 1:50.000. Após um pré-processamento, os conjuntos de dados foram recortados de acordo com os limites da sub-bacia de interesse, produzindo os mapas de fatores (sociais, econômicos, ambientais e agrícolas). Foram atribuídos pesos aos fatores por meio de uma matriz de comparação pareada. Foram examinados os efeitos do número de fatores e de seus pesos sobre a extensão e o grau de adequação dos locais. Devido à presença de grandes áreas não-agrícolas e residenciais na sub-bacia, 
apenas $16 \%$ da área foi considerada adequada para a aplicação de resíduos. A área resultante dessa avaliação de adequação foi dependente da área das restrições impostas por cada fator, enquanto que o grau de adequação foi função principalmente da distribuição dos pesos entre fatores.

Robinson et al. (2002) comentam que, em muitos países africanos, onde recursos governamentais e ajuda de doadores para o controle da tripanossomíase transmitida pela mosca tsé-tsé estão diminuindo, há uma necessidade crescente de se identificarem áreas onde a intervenção tem maiores probabilidades de ser sustentável, dos pontos de vista técnico, econômico, social e ambiental. Assim, as atividades deveriam se concentrar onde os benefícios obtidos de recursos limitados fossem maiores. Os autores descrevem uma abordagem de apoio à decisão baseada em SIG para identificar áreas de alta prioridade para o controle da tsé-tsé e da tripanossomíase, no "cinturão da mosca" no leste da Zâmbia. Foram gerados mapas digitais de seis variáveis: (1) densidade de gado; (2) densidade humana; (3) uso da terra; (4) potencial arável relativo do solo; (5) intensidade de uso do solo pelas culturas; e (6) proximidade a operações de controle existentes. A distribuição da mosca na área foi predita usando uma análise multivariada (Máxima Verossimilhança) de áreas com presença e ausência conhecidas e uma série de dados ambientais. Veterinários e biólogos experientes da Zâmbia, trabalhando na região, estabeleceram pesos para os critérios das variáveis de entrada e os dados foram integrados em um SIG, usando a CLP para a priorização de áreas para o controle da tripanossomíase.

Tagliani (2002) apresenta um estudo de avaliação da vulnerabilidade ambiental de uma região da Planície Costeira do Rio Grande do Sul, através da utilização de AMC no SIG Idrisi 32. Após a definição dos fatores de vulnerabilidade ambiental, foram aplicadas rotinas de apoio à decisão disponíveis no SIG. Inicialmente os fatores foram padronizados utilizando um conceito relativo, ou fuzzy e, posteriormente, agregados através do método da CLP, para a obtenção do mapa de vulnerabilidade ambiental relativa. O mapa apresentou uma amplitude de valores contínuos variando de 0 (vulnerabilidade baixa) a 255 (vulnerabilidade alta). Segundo o autor, a metodologia utilizada mostrou-se flexível, permitindo fácil e rapidamente a reavaliação de informações e critérios. Isso facilita, ainda segundo o autor, a obtenção de um 
consenso técnico e auxilia a tomada de decisão, aspectos extremamente importantes em programas de manejo integrado de zonas costeiras.

Baban e Wan-Yusof (2003) citam que falhas em várias barragens e o aumento da conscientização ambiental por parte da população irão requerer, cada vez mais, a inclusão de fatores sociais e ambientais, além dos técnicos e econômicos, no processo de determinação dos locais mais apropriados à construção de reservatórios. Nesse estudo, os autores desenvolveram e implementaram uma metodologia para determinar locais potenciais para reservatórios na ilha de Langkawi, Malásia, com base em diversos fatores considerados relevantes, como: relevo, geologia, hidrografia, uso e cobertura do solo e assentamentos humanos. Foram utilizados mapas digitais topográficos e geológicos e uma imagem de satélite para gerar os planos de informação necessários para os critérios determinados. O software Idrisi foi empregado para implementar a agregação dos critérios, usando-se os métodos Booleano e da CLP. O método Booleano gerou seis locais adequados à construção de reservatórios, dos quais apenas dois apresentaram boa correspondência com os locais apontados por estudos baseados em campo. O método da CLP produziu sete locais adequados ao objetivo do trabalho, cinco dos quais concordaram com aqueles gerados por estudos de campo. Os produtos obtidos indicaram que os critérios desenvolvidos foram sensíveis aos aspectos (cenários) físicos, ambientais e econômicos da ilha de Langkawi.

Salam, Khatun e Ali (2005) comentam que a avaliação de áreas adequadas à criação de carpas requer um esforço considerável em termos de coleta de informação, o que representa tanto oportunidades quanto limitações aos tomadores de decisão. Os autores apresentam um modelo baseado em SIG para identificar a adequação de locais para a produção de carpas, com base nos requerimentos biológicos da espécie, características do solo, disponibilidade de água, presença de rede viária, mercado, fontes de alevinos, tipos de serviço de extensão, insumos agrícolas e mão-de-obra. $O$ mapa de adequação foi gerado usando-se a AMC, pelo método da CLP.

Jiang e Eastman (2000) revisaram as duas principais abordagens empregadas em SIG, a Booleana e a Combinação Linear Ponderada (CLP), e discutiram questões e problemas associados a ambas. Para resolver as diferenças conceituais entre as duas abordagens, os autores propuseram a aplicação de medidas fuzzy, argumentando que 
os fatores padronizados da CLP pertencem à classe geral de medidas fuzzy e à instância mais específica de pertinência a um conjunto fuzzy. Essa perspectiva proporciona uma base teórica forte para a padronização de fatores e sua subseqüente agregação. Nesse contexto, é discutido pelos autores um novo operador de agregação que acomoda e estende as abordagens Booleana e CLP: a Média Ponderada Ordenada. Para ilustrar as diferentes abordagens, empregaram um estudo de caso referente à alocação industrial em Nakuru, Quênia.

A Média Ponderada Ordenada (MPO) é uma classe de operadores multicritérios introduzida por Yager (1988) e implementada em ambiente SIG por Eastman e Jiang (1996). Sua conceituação teórica, bem como dos demais métodos de agregação de critérios, será apresentada neste trabalho em item apropriado, no capítulo MATERIAL E MÉTODOS. Por ora serão revisados aqueles trabalhos envolvendo aplicações do método da MPO em ambiente SIG.

Araújo (1999) descreve a aplicação de técnicas de geoprocessamento na avaliação da favorabilidade de mineralizações de metais básicos, na área das folhas Cerro Azul e Apiaí, escala 1:100.000, Vale do Ribeira, SP e PR. O método utilizado baseou-se na seleção e ponderação de parâmetros prospectivos e aplicações destes segundo técnicas de geoprocessamento em um banco de dados digitais, composto por dados geológicos, geoquímicos, aerogeofísicos e de ocorrências minerais. A seleção dos parâmetros prospectivos e as análises foram feitas com base em dois modelos de mineralização: o tipo Panelas, filonar hidrotermal encaixado em rochas carbonáticas, e o tipo Perau, sedimentar-exalativo. A agregação dos níveis de informação, gerados a partir dos parâmetros prospectivos e do banco de dados, foi efetuada pelos seguintes métodos: Booleano, Combinação Linear Ponderada e Média Ponderada Ordenada. O método Booleano não foi considerado adequado à análise de favorabilidade nos casos estudados. Os métodos CLP e MPO mostraram-se adequados a esse tipo de análise, na área de estudo, com resultados semelhantes entre si. A análise por MPO definiu os melhores resultados, com os mapas de favorabilidade obtidos mostrando um maior número de classes em pequenas áreas. Em comparação, a análise por CLP apresentou resultados coerentes, mas sem detalhar as áreas menores. Os parâmetros prospectivos desenvolvidos mostraram-se adequados qualitativa e quantitativamente, tanto para 0 
tipo Perau quanto para o tipo Panelas. O autor conclui que o método utilizado é adequado à seleção de áreas para pesquisa geológica em detalhe a baixos custos, podendo ser aplicado em áreas semelhantes à estudada.

Calijuri; Mello e Lorentz (2002) apresentam a metodologia utilizada na avaliação e seleção de áreas para a implantação de aterros sanitários no município de Cachoeiro do Itapemirim, ES, com uso de AMC e SIG. Na agregação dos critérios foram utilizados dois procedimentos: CLP e MPO. Os resultados obtidos revelaram que o método de análise estratégica de decisão, viabilizado pelo SIG, permite a integração de informações espaciais para tomada de decisão no processo de avaliação e seleção de áreas para a implantação de empreendimentos impactantes.

Malczewski et al. (2003) propõem uma abordagem usando um parâmetro que serve como um mecanismo para guiar procedimentos de avaliação multicritérios. O parâmetro é incorporado a um método para obter os pesos de ordenação ótimos e para desenvolver uma função de transformação. A função fornece um meio consistente de modificar os valores dos critérios, de modo que os procedimentos de combinação multicritérios possam ser guiados pela especificação de um único parâmetro. O método MPO-parametrizado foi implementado em ambiente SIG como um módulo SIG-MPO e foi testado em uma situação real para desenvolver estratégias de manejo na bacia hidrográfica de Cedar Creek, em Ontário, Canadá. Dado um conjunto de critérios de avaliação, o problema era avaliar áreas na bacia para projetos de reabilitação e melhoramento. Usando o método SIG-MPO foi gerado um certo número de estratégias alternativas para projetos de reabilitação e melhoramento que, posteriormente, foram avaliadas.

Valente e Vettorazzi (2005) empregaram a AMC, por meio do método da MPO, para definir áreas prioritárias para conservação e preservação florestal na bacia do Rio Corumbataí, SP. Os fatores considerados importantes foram: proximidade aos fragmentos florestais, proximidade às áreas florestais com maior área nuclear, proximidade à rede hidrográfica, distância às estradas, distâncias às áreas urbanas e vulnerabilidade do solo à erosão. Foram então gerados e avaliados mapas de prioridade, com riscos baixo, médio e alto. Esses mapas foram reclassificados para exibir apenas cinco níveis de prioridade: muito baixa, baixa, média, alta e muito alta. A 
melhor alternativa foi o mapa referente ao risco alto $(R=0,40)$ e compensação de $78 \%$ entre fatores. O método da MPO foi considerado eficiente na determinação de áreas prioritárias à conservação e à preservação florestal, em ambiente SIG, na área de estudo.

\subsection{SIG e definição de áreas prioritárias à conservação da água e do solo em nível de bacias hidrográficas}

As bacias hidrográficas incluem diversos recursos naturais que proporcionam bens e serviços à sociedade e que sustentam uma variedade de funções de ecossistemas. O planejamento cuidadoso em nível de bacia hidrográfica é crítico para proteger esses recursos. Entre os vários recursos naturais, a água é um dos fatores primários que influenciam a distribuição e a qualidade de várias formas de vida e ecossistemas. Além de a água ser essencial à sobrevivência humana, diversas atividades econômicas dependem da quantidade e da qualidade dos recursos hídricos. Nas últimas décadas, esse recurso vital tem estado sujeito a uma rápida deterioração, resultante da expansão das atividades antrópicas (Randhir et al., 2001).

Para Karnib (2004), a escassez é um problema importante entre os muitos problemas relacionados à água que estão presentes hoje e que serão ainda mais notáveis no futuro. Muitos países em desenvolvimento têm realizado projetos na área de recursos hídricos para satisfazer sua demanda por água. Não há, em geral, capacidade financeira para executar todos esses projetos em bloco, assim é importante elaborar um plano de ações prioritárias, para identificar a seqüência de projetos a serem executados, em uma ordem de prioridades.

Wilson e Droste (2000) citam que está sendo dada uma atenção crescente ao gerenciamento de recursos hídricos em escala de bacia hidrográfica e que há necessidade de uma abordagem multidisciplinar na coleta e análise dos dados, que são a base das análises necessárias às tomadas de decisão. Segundo os autores, avaliações tradicionais de qualidade e quantidade de água estão se juntando a avaliações biológicas, geomorfológicas e antropológicas, como a valoração econômica. Esse domínio de avaliação integrada leva a uma reavaliação dos instrumentos de 
Tecnologia da Informação, como o SIG, projetados para dar suporte ao processo de gerenciamento.

Tim; Jain e Liao (1996) comentam que a tecnologia SIG tem emergido como um instrumento extremamente efetivo para a análise e priorização de alternativas de manejo de recursos naturais. Devido ao fato dos problemas de manejo dos recursos naturais serem de natureza espacial, a tecnologia SIG propicia os instrumentos para se definir a extensão do problema e facilita o projeto e a implementação de estratégias alternativas de manejo. A flexibilidade de um SIG, somada à sua capacidade de integrar modelos com dados espaciais, oferece a gerentes e planejadores os instrumentos para, efetivamente, manejar recursos naturais e avaliar a implementação de políticas regulatórias antes de sua implementação.

Segundo Vlahos e Herbst (2000), a preservação das terras de bacias hidrográficas representa um dos métodos mais efetivos e econômicos de assegurar suprimentos adequados e seguros de água. Os autores apresentam uma metodologia para priorizar terras não desenvolvidas em bacias hidrográficas, visando à proteção da qualidade da água, com emprego da tecnologia SIG. As terras são avaliadas com base em seus aspectos físicos e nível de desenvolvimento, gerando informações úteis aos responsáveis pelo manejo das terras, tomadores de decisão com limitação de tempo e organizações com limitação de fundos.

Miller; Guertin e Heilman (2004) citam que a tomada de decisão em manejo de bacias hidrográficas é um processo complexo, requerendo, em geral, a cooperação e comunicação entre agentes federais, estaduais e locais, no balanceamento de aspectos biofísicos e socioeconômicos. O público está tomando parte em decisões ambientais, com isso está aumentando a necessidade de transferência de tecnologia de agências públicas para os atores locais. A Tecnologia da Informação tem tido uma profunda influência no manejo de bacias hidrográficas ao longo da última década. Avanços na aquisição de dados por meio de sensoriamento remoto, análises dos dados em SIGs e compartilhamento de dados através da Internet têm proporcionado acesso a mais informação aos profissionais envolvidos no gerenciamento de bacias. No futuro, aplicativos envolvendo modelos de simulação hidrológica, SIG e sistemas de apoio à decisão deverão ser disponibilizados através da Internet. Em adição a desafios, tais 
como tornar a complexa tecnologia de modelagem disponível a públicos diversos, novos temas da Tecnologia da Informação, como interoperabilidade, acesso à Internet e segurança, são introduzidos quando SIG, modelos de simulação e sistemas de apoio à decisão são integrados em um ambiente de Internet.

Currey-Gregory e Crosby (1995) comentam que a proteção de microbacias hidrográficas é uma abordagem geográfica ao manejo de recursos hídricos, adotada por uma série de agências estaduais de manejo de recursos hídricos e promovida em nível nacional, nos EUA, pela Environmental Protection Agency (EPA), entre outras agências do governo federal americano. Segundo os autores, a chave para o sucesso na abordagem de proteção de microbacias é a capacidade de identificar, visualizar e priorizar problemas de qualidade da água para ações de manejo em microbacias. Essas atividades requerem numerosos tipos de dados ambientais e relacionados. Os SIGs são um bom instrumento para avaliar, gerenciar e analisar esses dados em uma base geográfica. Tanto a EPA quanto outras agências americanas têm aplicado com sucesso o SIG em projetos de manejo de recursos hídricos.

Com relação à priorização de microbacias para programas de conservação, com auxílio de SIG, Snell; Monk e Dance (1995) comentam que o processo deve atender a uma série de critérios: ter por base os ecossistemas; ser descentralizado; dar suporte à diversidade e a uma economia sustentável; ser participatório; identificar problemas prioritários; e não ser muito caro. No programa apresentado pelos autores foi proposta uma grande rede de áreas naturais em nível de microbacias, em Ontário, Canadá, com a identificação de áreas que necessitavam de recomposição.

Biswas; Sudhakar e Desai (2002) citam que programas de conservação de recursos naturais são essenciais à sustentação de qualquer atividade de desenvolvimento e, tais medidas, especialmente para solo e água, conduzidas em nível de microbacia hidrográfica, são muito úteis ao gerenciamento de recursos hídricos. Nesse contexto, as ações de priorização são requeridas para diferentes componentes das microbacias, assim como para se tomar medidas posteriores relevantes de conservação. Segundo os autores, avanços tecnológicos recentes têm tornado as técnicas de sensoriamento remoto e de SIG instrumentos importantes para a recomendação dessas medidas conservacionistas. Pode-se inferir, a partir desse 
estudo, que a priorização de microbacias é essencial e que o SIG é um instrumento efetivo na recomendação de ações apropriadas.

Corwin; Loague e Ellsworth (1999) mencionam que a Era da Informação tem levado a uma conscientização e também preocupação com relação a problemas ambientais globais, tais como mudanças climáticas, redução da camada de ozônio, desmatamentos, desertificação e poluição de fontes não pontuais, ou difusa. Os autores consideram a poluição difusa como a maior ameaça individual à água potável, tanto superficial como sub-superficial. A poluição difusa também representa uma ameaça à agricultura sustentável, que é vista como o meio mais viável de atender à demanda por alimentos de uma população mundial crescente. A capacidade de avaliar com acurácia os impactos presentes e futuros da poluição difusa sobre os ecossistemas, da escala local à global, é um instrumento poderoso para o gerenciamento ambiental e para guiar futuras atividades humanas. Os autores comentam que a avaliação da poluição difusa é um problema multidisciplinar e para abordá-lo são necessárias tecnologias avançadas de informação e metodologias provenientes das mais diversas áreas do conhecimento, que possam ser aplicadas em um contexto espacial.

Subra e Waters (1996) citam que a poluição difusa, um dos principais contribuintes da degradação da qualidade da água, é causada pelo movimento da água sobre e através da camada superficial do solo. A localização de fontes de poluição difusa, tipos de áreas drenadas e canais de escoamento são dados vitais nas atividades agrícolas, florestais e de planejamento regional. Esses dados podem ser usados por agências locais, estaduais ou federais, para fim de planejamento ou para priorizar a alocação de recursos.

Diferentes abordagens podem ser empregadas na priorização de áreas para conservação de água e solo em bacias hidrográficas. Na literatura pertinente, um número significativo de trabalhos aponta para o emprego de índices relacionados à erosão, envolvendo análises de múltiplos critérios, principalmente na Índia, onde as atividades de conservação de água e solo em nível de microbacias recebem uma atenção especial do governo. A seguir são apresentados exemplos de trabalhos que empregaram índices relacionados à erosão na determinação de áreas prioritárias para conservação em microbacias. 
Kudrat; Tiwari e Saha (1997) ilustram a utilidade de técnicas de sensoriamento remoto e SIG na modelagem quantitativa da produção real e potencial de sedimentos e o Índice de Erosão de Microbacias (Erosion Index of Watershed) por meio do estudo de caso da microbacia Song (Doon Valley, distrito de Dehradun, Índia). O Índice de Erosão tem sido usado para a priorização de sub-bacias na microbacia estudada. Os resultados indicaram que, de um total de 23 sub-bacias, sete pertenciam às classes de prioridade alta e muito alta, necessitando de medidas imediatas de conservação do solo.

Dutta et al. (1997) apresentam a utilidade de informações sobre solos, derivadas de dados digitais georreferenciados do satélite indiano IRS LISS II (escala 1:50.000), em combinação com declividade do terreno e informações sobre microbacias hidrográficas geradas a partir de cartas topográficas (1:50.000) e fotografias aéreas (1:25.000) para avaliação da severidade da erosão do solo em 125 microbacias na Índia. As médias ponderadas de diferentes tipos de solo nas microbacias foram ranqueadas de acordo com sua erodibilidade e integradas com variáveis topográficas e hidrológicas para se obter valores do Índice de Produção de Sedimentos, que foram posteriormente agrupados em quatro categorias (muito alto, alto, médio e baixo). Os autores concluíram que os dados de solo e fisiografia, obtidos a partir da interpretação e análise de dados de sensoriamento remoto, podem ser efetivamente usados na avaliação qualitativa de risco de erosão e priorização de microbacias.

Adinarayana et al. (1999), com auxílio de técnicas de geoprocessamento, aplicaram a Equação Universal de Perda de Solo e o Índice de Produção de Sedimentos no delineamento de sub-bacias prioritárias para programas de conservação de solo e água, na Índia. Os autores comentam que a introdução da abordagem multidisciplinar na metodologia, com opiniões de especialistas em várias áreas, pode proporcionar uma extensão aos métodos tradicionais de avaliação da erosão do solo, permitindo a análise de diferentes cenários de manejo da microbacia.

Biswas; Sudhakar e Desai (1999) testaram uma abordagem alternativa ao emprego do Índice de Produção de Sedimentos, com base em uma análise morfométrica da bacia, na priorização de unidades (sub-bacias) para conservação de solo e água. Os autores comentam que técnicas de sensoriamento remoto e de SIG 
têm sido efetivamente usadas como instrumentos para a descrição quantitativa da geometria de bacias hidrográficas, isto é, análise morfométrica. Estudaram nove subbacias em West Bengala, Índia, em termos dos parâmetros morfométricos, e também calcularam para elas o Índice de Produção de Sedimentos. Os resultados foram, em sua maior parte, coincidentes, no que se refere à priorização das sub-bacias. Isso indica que a análise morfométrica poderia ser usada para priorização de áreas, mesmo sem a disponibilidade de mapas de solo confiáveis da área de estudo.

Randhir et al. (2001), com base em diversos critérios topográficos, hidrológicos e de solos, desenvolveram um modelo para mapear áreas altamente sensíveis, consideradas prioritárias a políticas e práticas conservacionistas na bacia do Ware River, em Massachusetts, EUA. Comentam que as bacias hidrográficas vêm-se tornando a unidade padrão no planejamento de recursos naturais, especialmente para proteger a qualidade da água. Ainda segundo os autores, Os altos custos de implantação e manutenção de obras civis, bem como de projetos de restauração de bacias, fazem dessa abordagem de priorização de áreas sensíveis uma alternativa economicamente viável na proteção de recursos hídricos.

Jain e Goel (2002) citam que a investigação de bacias hidrográficas, para planejamento de conservação do solo, requer uma abordagem seletiva para identificar unidades hidrológicas menores, que seriam mais adequadas a programas de conservação mais eficientes. Um critério, geralmente usado para determinar a vulnerabilidade de microbacias à erosão, é a produção de sedimentos. Na Índia, dados quantitativos de sedimentos não são geralmente coletados para pequenas bacias e torna-se difícil identificar as áreas mais vulneráveis à erosão, que poderiam ser tratadas com relação a uma hierarquia de prioridades. Sugere-se nesse estudo uma abordagem empregando um índice, com base nos principais fatores superficiais responsáveis pela erosão do solo. Esses fatores incluem o tipo de solo, vegetação, declividade do terreno e várias propriedades das microbacias, tais como densidade de drenagem, fator de forma etc. O método é ilustrado com um estudo de caso de microbacias imediatamente a montante do Reservatório de Ukai, localizado no rio Tapi, Estado de Guajarat. A área foi dividida em 16 microbacias e diferentes parâmetros relacionados com tipo de solo, vegetação, relevo e morfologia, foram estimados separadamente para cada microbacia. 
Dados de satélite foram usados para a avaliação do solo e da vegetação, enquanto o SIG foi usado para avaliar o relevo e os índices relacionados à morfologia das microbacias. O efeito integrado de todos os parâmetros foi avaliado para delimitar diferentes áreas vulneráveis à erosão do solo. Duas microbacias foram identificadas como sendo as mais suscetíveis à erosão. Com base no índice integrado, foi recomendada uma escala de microbacias prioritárias para programas de conservação de solo e água.

Como é possível depreender da revisão, independentemente do método ou índice empregado, a avaliação envolvendo múltiplos critérios está presente em muitos trabalhos relacionados à priorização de áreas para fim de conservação de solo e água.

\subsection{Restauração de áreas florestais}

A conversão de áreas florestais a outras coberturas e usos do solo, como pastagens, agricultura, mineração, urbanização etc., tem gerado impactos negativos sobre os recursos naturais terrestres, como a perda de biodiversidade, erosão do solo, diminuição da quantidade e da qualidade da água etc.

A relação entre recursos hídricos e uso e cobertura do solo é reconhecida há muito tempo, porém, apenas mais recentemente, com o agravamento da situação envolvendo a disponibilidade de água de qualidade é que a atenção tem-se voltado à questão de conservação e preservação de áreas florestais, principalmente em nível de bacia hidrográfica, visando à conservação de recursos hídricos.

Lima (2005) comenta que "a saúde ambiental ou a estabilidade hidrológica da microbacia deve ser entendida como condição viável ou sustentável de equilíbrio dinâmico, compatível com a necessidade de uso dos recursos naturais pela sociedade". Ou seja, segundo o autor, há espaços na paisagem para a produção de alimentos, fibras e outros bens e serviços demandados pela sociedade, mas existem espaços com vocação nítida para a proteção dos processos ecológicos e hidrológicos que mantêm a estabilidade das microbacias.

Nesse sentido, ainda de acordo com Lima (2005), é de particular importância o planejamento adequado da diversidade biológica na escala da microbacia, visando a 
proteger adequadamente as zonas ripárias e cabeceiras de drenagem, incluindo a dinâmica temporal dessas áreas, necessária para garantir a integridade do sistema ripário - conjunto dos fatores bióticos que envolvem a mata ciliar e interações com a fauna e abióticos, representados pelas áreas saturadas das cabeceiras de drenagem e das margens dos riachos.

A integridade do ecossistema ripário, segue o autor, é um dos fatores-chave de resiliência da microbacia, ou seja, de sua capacidade de sofrer alterações sem perder a funcionalidade hidrológica. Ao perder a resiliência, o sistema torna-se mais vulnerável a perturbações que, de outra forma, poderiam ser absorvidas sem mudanças em funções, padrões e controles naturais. No caso da degradação dos recursos hídricos, não há dúvida de que um dos fatores responsáveis por esse processo é a perda gradativa da resiliência em incontáveis microbaciais, ocasionada principalmente pela destruição do sistema ripário.

O autor comenta que, "na busca da sustentabilidade, implicando o uso harmônico dos recursos naturais e a conservação dos recursos hídricos, torna-se necessário reverter esse quadro. Para isso, faz-se necessário agregar resiliência aos ecossistemas ripários, o que pode ser conseguido por ações e mudanças no enfoque que incluam, por exemplo, a identificação dos limites das zonas ripárias das microbacias, idealmente incluindo sua dinâmica temporal; a restauração de suas funções, por meio da regeneração da vegetação ripária; a minimização das travessias dos cursos d'água, de sorte a minimizar os impactos hidrológicos; a adequação do sistema viário, evitando os impactos sobre as zonas ripárias". Conclui o autor comentando que, evidentemente, essas ações, de forma isolada, não constituem panacéia, já que a perpetuação do ecossistema ripário e de suas funções hidrológicas depende fundamentalmente da aplicação sistemática de práticas sustentáveis de manejo dos recursos naturais.

Vários são os trabalhos que abordam a relação entre qualidade da água e cobertura florestal. Plamondon et al. (1991), por exemplo, avaliaram os efeitos de diferentes usos da terra sobre a fertilidade do solo e a qualidade da água em três subbacias da microbacia hidrográfica de Oxapampa, Peru. A substituição da floresta natural por pastagens e culturas agrícolas levou ao decréscimo nos teores de matéria 
orgânica, nitrogênio, fósforo e potássio no solo. Em adição, o aumento no alumínio trocável causou uma diminuição substancial na fertilidade do solo três ou mais anos após a retirada da floresta.

Scott et al. (2002) comentam que rios integram processos biogeoquímicos, operando em escalas espaciais amplas a locais e em escalas temporais de longo e de curto prazos. Comentam os autores que, na América do Norte, o ser humano tem alterado extensivamente tais processos, com sérias conseqüências para os ecossistemas aquáticos. Foram coletados dados em tributários do Alto Rio Tennessee, na Carolina do Norte, EUA, para: (1) comparar o uso da terra e a geomorfologia, com respeito à sua capacidade de explicar variações na qualidade da água, medidas de sedimento e grandes resíduos de madeira; (2) determinar se a mudança na paisagem ao longo do tempo contribuiu significativamente para explicar as condições atuais dos rios; e (3) avaliar a importância da escala espacial no exame das influências do uso da terra sobre os rios. Variáveis dos rios foram relacionadas tanto ao uso da terra como à geomorfologia da paisagem. A cobertura florestal foi responsável pela maior parte da variação em quase todos os modelos, apoiando predições de enriquecimento por nutrientes, poluição termal e sedimentação, causados por perturbações da paisagem. Efeitos de perturbações nas bacias, no passado, foram aparentes nas medidas de sedimentos. Concentrações de nitrogênio e de fósforo, bem como temperatura da água, foram menores onde as áreas ripárias foram reflorestadas. Modelos de físico-química dos rios ajustaram-se melhor quando os preditores foram em nível de bacia em vez de mais localizados (i.e., dentro de $2 \mathrm{~km}$ de um sítio amostral). Impactos cumulativos sobre os rios, devido a alterações no uso da terra, devem ser administrados a partir da perspectiva da bacia hidrográfica, com modelos quantitativos que integrem através das escalas.

Perry et al. (1999) empregaram um SIG e dados oficiais de uso da terra do Estado da Georgia, EUA, para identificar o uso da terra na bacia experimental do Little River (com $333 \mathrm{~km}^{2}$ ) e realizar uma variedade de análises espaciais com o objetivo de determinar o impacto do manejo da floresta ripária na bacia sobre a qualidade da água. A bacia apresenta uma rede de drenagem densa, dendrítica, com aproximadamente $54 \%$ de ambos os lados de canais de segunda ordem ou maiores com uma faixa de 
$30 \mathrm{~m}$ de vegetação florestal ripária. Aproximadamente $60 \%$ das terras altas encontravam-se sob algum tipo de produção agrícola. Foram usadas análises em SIG para extrapolar medidas em escala de campo para a escala de bacia, da capacidade de filtragem da floresta ripária em relação a sedimentos e nutrientes (poluição difusa ou não pontual) e para avaliar o impacto sobre a qualidade da água de três cenários crescentes de desflorestamento e três cenários crescentes de reflorestamento na zona ripária. As cargas de nitrogênio e fósforo na saída da bacia poderiam aumentar potencialmente de $16,7 \%$ e 9,5\%, respectivamente, sob um cenário de desflorestamento de $50 \%$ da floresta ripária. Diminuições nas cargas de nitrogênio e fósforo de 13,2\% e 7,4\%, poderiam ocorrer sob um cenário de reflorestamento de 50\% da zona ripária. A análise da fragmentação da zona ripária indicou que somente seis blocos de floresta, com pelo menos $2 \mathrm{~km}$ de comprimento, permanecem na bacia, confirmando o estado de fragmentação da floresta ripária.

Em certas situações, como é o caso de muitas bacias hidrográficas em regiões desenvolvidas, a cobertura florestal foi tão intensamente removida, que apenas projetos de restauração em grande escala podem devolver parte dos elementos e funções do ecossistema original.

Segundo Souza e Batista (2004), a Ecologia da Restauração é objeto de crescente interesse e pesquisa no Brasil. Apesar das altas taxas de fragmentação na Mata Atlântica e ecossistemas associados, poucas tentativas de restaurar áreas desmatadas, em grande escala, têm sido feitas.

Palik et al. (2000) citam que o restabelecimento de comunidades de plantas nativas é um objetivo importante de restauração de ecossistemas. Em paisagens complexas, contendo diversos tipos de ecossistema, a restauração requer um conjunto de condições de referência da vegetação para o ecossistema em questão e um modelo preditivo para relacionar a composição da comunidade vegetal a variáveis físicas. A restauração também requer uma abordagem para priorizar esforços, facilitando assim a alocação de recursos institucionais, em geral, limitados. Para os autores, o desenvolvimento de um índice de prioridade para paisagens específicas requer uma compreensão dos relacionamentos hierárquicos entre geomorfologia, características do solo e comunidades vegetais, além de objetivos bem definidos de restauração. 
Harrington (1999) cita que, embora a idéia de plantios para a restauração de ecossistemas seja relativamente recente, muitos dos primeiros plantios de árvores em grande escala foram realizados com objetivos referidos hoje como de "restauração" ou de "conservação". A restauração de florestas pode ser necessária quando ecossistemas são perturbados por forças naturais ou antrópicas. Essas perturbações podem causar impactos: (1) nos componentes básicos do sistema (p.ex. composição de flora e fauna); (2) nos processos do ecossistema, isto é, interações entre componentes básicos; e (3) em ambos, componentes e processos. Os primeiros esforços de restauração ou reabilitação focavam principalmente na redução de impactos resultantes de perturbações fora das áreas a serem restauradas, tais como carreamento aos cursos d'água de sedimentos provenientes de ecossistemas severamente perturbados. Programas mais recentes de restauração incluem ecossistemas nos quais apenas alguns dos componentes foram perdidos ou alguns dos processos tenham sido impactados.

Llewellyn et al. (1996) citam que a conversão de áreas úmidas florestadas ao uso agrícola e a fragmentação resultante da paisagem têm levantado preocupação quanto à integridade funcional do ecossistema da planície aluvial do Rio Mississippi, EUA. Os autores descrevem o esforço desenvolvido pela ONG The Nature Conservancy para iniciar uma parceria dedicada a criar e implementar um projeto de restauração em nível de paisagem, viável e cooperativo, na planície aluvial do Rio Mississippi. Fases importantes do processo durante os cinco primeiros anos foram: (1) início do desenvolvimento de uma rede extensa de parcerias, incluindo agências estaduais e federais, proprietários de terras, grupos conservacionistas, acadêmicos e outros cidadãos interessados; (2) desenvolvimento de um SIG para todo o ecossistema; e (3) para uma única microbacia (Tensas, no nordeste da Louisiana), foi realizado um refinamento no SIG (maior resolução), gerando estatísticas de conversão de uso da terra mais detalhadas, para demonstrar a exeqüibilidade de um procedimento de planejamento de restauração em escala de paisagem, incluindo a metodologia para priorização de remanescentes florestais existentes e áreas mais adequadas ao reflorestamento e conexão via corredores. 
Richardson e Gatti (1999) citam que a maioria dos programas de restauração de áreas úmidas em Wisconsin, EUA, tem visado aos benefícios à vida silvestre, sem considerações sobre a melhoria da qualidade da água. Assim, foi desenvolvido um banco de dados em SIG para uma microbacia no sul de Wisconsin, para locar objetivamente áreas úmidas drenadas e seus proprietários e para ranquear essas áreas para fim de restauração, com base em seu potencial para promover a melhoria da qualidade da água. Foi usada a Equação Universal de Perda de Solo (EUPS) no SIG, a partir dos planos de informação sobre solos, manejo das culturas, relevo, hidrografia e cobertura do solo, para estimar a produção potencial de sedimentos carreados aos rios na microbacia. O SIG foi então usado para delinear sub-áreas em cada microbacia, para estimar a quantidade de sedimentos que poderia ser bloqueada se a microbacia fosse restaurada e para ranquear as áreas úmidas drenadas para fim de restauração.

Burkart; James e Tomer (2004) exploraram métodos de mapeamento de variáveis hidrológicas para locar buffers de vegetação ripária. Dados de elevação do terreno e de vazão foram usados para definir índices de umidade, fluxo de base, transporte de sedimentos e de descarga. A água subterrânea domina a descarga em cursos d'água muito pequenos e através das áreas ripárias na região. Todos os índices mostraram que as áreas ripárias ao longo dos canais de primeira ordem têm maior potencial de interceptação da água subterrânea ou superficial (runoff) que áreas similares ao longo de canais de ordem maiores.

Jones et al. (2001) citam que a identificação espacialmente explícita em mudanças nas condições ecológicas em grandes áreas é um ponto chave para a priorização de áreas para proteção ambiental e restauração, em escalas de microbacia hidrográfica, bacia e regional. Uma limitação crítica a isso tem sido o desenvolvimento de métodos para conduzir as avaliações em tais escalas. Métodos de campo são muito caros e inconsistentes em sua aplicação na estimativa de condições ecológicas sobre grandes áreas. Novos dados espaciais derivados de imagens de satélites e outras fontes, o desenvolvimento de modelos estatísticos relacionando composição e padrão da paisagem a objetivos ecológicos e técnicas de SIG, tornam possível a avaliação de condições ecológicas em múltiplas escalas sobre amplas regiões. 
Feist et al. (2003) comentam que a percepção de quais atributos dos habitats são importantes em projetos de restauração é uma função da escala de observação e que os esforços de restauração devem focar sobre condições em escalas de bacia hidrográfica ou de paisagem, em projetos locais de restauração.

Segundo Ashton et al. (2001), nos últimos dez a quinze anos o governo do Sri Lanka tem mudado sua política relativa aos remanescentes florestais, deixando de lado a exploração comercial e caminhando no sentido da conservação. Essa mudança temse fundamentado no reconhecimento da crescente importância das microbacias em terras altas para a produção de água, conservação da biodiversidade e outros serviços. Foi feita então uma revisão de quinze anos de investigações científicas sobre a dinâmica florestal no sudoeste do Sri Lanka, com o objetivo de usar esse conhecimento nas atividades de restauração florestal.

De acordo com Sweeney; Czapka e Yerkes (2002), o restabelecimento da floresta ripária é freqüentemente visto como a melhor prática de manejo para restaurar áreas (ecossistemas) ao redor dos cursos d'água a um estado quase natural e prevenir a entrada de fontes contaminantes não pontuais.

Machado, Vettorazzi e Xavier (2003) empregaram o modelo SWAT (Soil and Water Assessment Tool) na simulação de cenários alternativos de uso da terra na microbacia hidrográfica do Ribeirão dos Marins, em Piracicaba, SP, no biênio 1999/2000. Dois cenários foram simulados. No primeiro, foi mantida uma faixa de mata ciliar de $30 \mathrm{~m}$ em toda a extensão dos cursos d'água e de $50 \mathrm{~m}$ ao redor das nascentes, de acordo com o Código Florestal. No segundo cenário, como as pastagens ocupavam 30,9\% da área da microbacia, nas encostas mais íngremes, com alto potencial erosivo, as áreas de pastagem foram substituídas por vegetação florestal. As simulações dos dois cenários foram comparadas com as condições do cenário atual em termos de produção de sedimentos. Os cenários geraram diferentes padrões espaciais da produção de sedimentos. Uma redução de $94 \%$ na produção de sedimentos foi obtida com a substituição da pastagem por vegetação nativa (cenário 2). No cenário 1 , a redução foi de 10,8\%. Esses resultados evidenciam a necessidade de tratar a paisagem em bacias hidrográficas de forma global, identificando as "áreas sensíveis ambientalmente“, onde são necessárias práticas de controle dos processos erosivos e 
não somente práticas de proteção dispensadas aos cursos d'água por meio da mata ciliar. 
3 MATERIAL E MÉTODOS

\subsection{Material}

\subsection{1 Área de estudo}

\subsubsection{Localização}

A bacia do Rio Corumbataí localiza-se na porção centro-leste do Estado de São Paulo, entre os paralelos $22^{\circ} 04^{\prime} 46^{\prime \prime} \mathrm{S}$ e $22^{\circ} 41^{\prime} 28^{\prime \prime} \mathrm{S}$ e os meridianos $47^{\circ} 26^{\prime} 23^{\prime \prime} \mathrm{W}$ e $47^{\circ} 56^{\prime} 15^{\prime \prime}$ W, ocupando uma área aproximada de $171 \mathrm{~km}^{2}$. Seu perímetro é de 301,5 km, apresentando 63,7 km de extensão na direção norte-sul e 26,8km (maior largura) na direção leste-oeste (Figura 1).

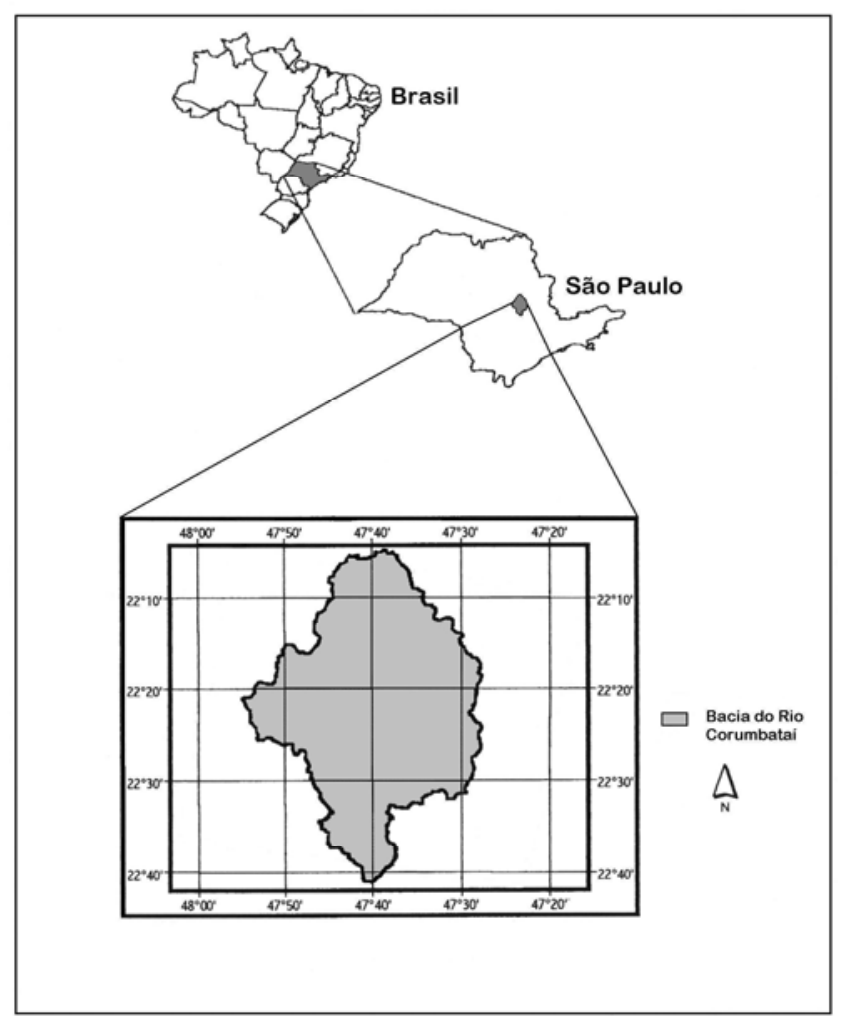

Figura 1 - Localização da área de estudo 
A bacia do Rio Corumbataí está localizada na Primeira Zona Hidrográfica do Estado de São Paulo, abrangendo a parte superior da bacia do Rio Tietê, desde suas cabeceiras até a Barragem de Barra Bonita, num percurso de $592 \mathrm{~km}$. Esta zona drena $32.710 \mathrm{~km}^{2}$, compreendendo dez bacias hidrográficas.

Fazem parte da bacia, integralmente, os municípios de Corumbataí, Ipeúna, Rio Claro e Santa Gertrudes. Parcialmente, fazem parte ainda os municípios de Analândia, Charqueada, Itirapina e Piracicaba.

\subsubsection{Clima}

O clima da região onde se encontra a bacia do Rio Corumbataí é do tipo Cwa, de acordo com a classificação de Köppen, sendo caracterizado como subtropical, seco no inverno e chuvoso no verão, com temperatura média do mês mais quente superior a $22^{\circ} \mathrm{C}$. As temperaturas mais altas ocorrem no período de dezembro a março e as mais baixas em junho e julho, com $17^{\circ} \mathrm{C}$ de temperatura média (SALATI, 1996).

O regime de chuvas é tropical, com duas estações definidas: um período seco, de março a setembro, com menos de $20 \%$ da precipitação anual, e um período chuvoso, de outubro a fevereiro, com mais de $80 \%$ da precipitação anual. O total precipitado no ano é ao redor de 1530 mm em Ipeúna (KOFFLER, 1994), 1390 mm em Rio Claro (TROPPMAIR; MACHADO, 1974) e 1278 mm em Piracicaba (SENTELHAS et al., 1998).

\subsubsection{Geologia}

A bacia do Rio Corumbataí é um exemplo de bacia hidrográfica desenvolvida a partir do Cenozóico, com cabeceiras nas cuestas da Serra Geral, em litologias típicas da Bacia Sedimentar do Paraná. É composta pelas formações Rio Claro, Pirambóia, Corumbataí e Iratí (KOFFLER, 1994). Geologicamente, a referida bacia hidrográfica localiza-se na Bacia Sedimentar do Paraná, sendo ali encontradas litologias relativas ao Cenozóico, ao Mesozóico e ao Paleozóico (KOFFLER, 1993). 
A seguir é apresentada, de forma resumida, a constituição geológica da bacia, de acordo com Koffler (1994):

- Formação Rio Claro: arenitos, arenitos conglomeráticos e arenitos argilosos; restritos à região de Ipeúna;

- Formação Pirambóia: arenitos finos a médios, síltico argilosos de coloração avermelhada, intercalados por níveis de argilito, folhelhos e arenitos argilosos de cores variadas; típicos de ambiente fluvial e de planície de inundação;

- Formação Corumbataí: argilitos, folhelhos sílticos cinza, arroxeados ou avermelhados, associados a depósitos de planície de maré;

- Formação Iratí: siltitos, argilitos, folhelhos sílticos cinza, folhelhos pirobetuminosos intercalados com calcário creme, de ambiente marinho raso.

O mapa geológico da bacia do Rio Corumbataí é apresentado na Figura 2.

\subsubsection{Relevo}

Segundo Viadanna (1985), a paisagem regional é monótona, predominando extensas áreas suavemente onduladas, interrompidas por escarpas arenítico-basálticas e cortadas por uma rede de drenagem com padrão dendrítico.

O relevo da bacia, de acordo com Koffler (1993), é representado principalmente por duas modalidades:

- Morrotes alongados e espigões: predominam interflúvios sem orientação preferencial, topos angulosos e achatados e vertentes ravinadas com perfis retilíneos; rede de drenagem de densidade média a alta, padrão dendrítico e vales fechados; e

- Colinas médias e amplas: predominando interflúvios com áreas de $1 \mathrm{~km}^{2}$ a mais de $4 \mathrm{~km}^{2}$, topos aplainados, vertentes com perfis convexos e retilíneos que se conectam à drenagem de média a baixa densidade e padrão sub-angular, vales abertos e fechados, planícies interiores restritas à presença de lagoas perenes ou intermitentes. 


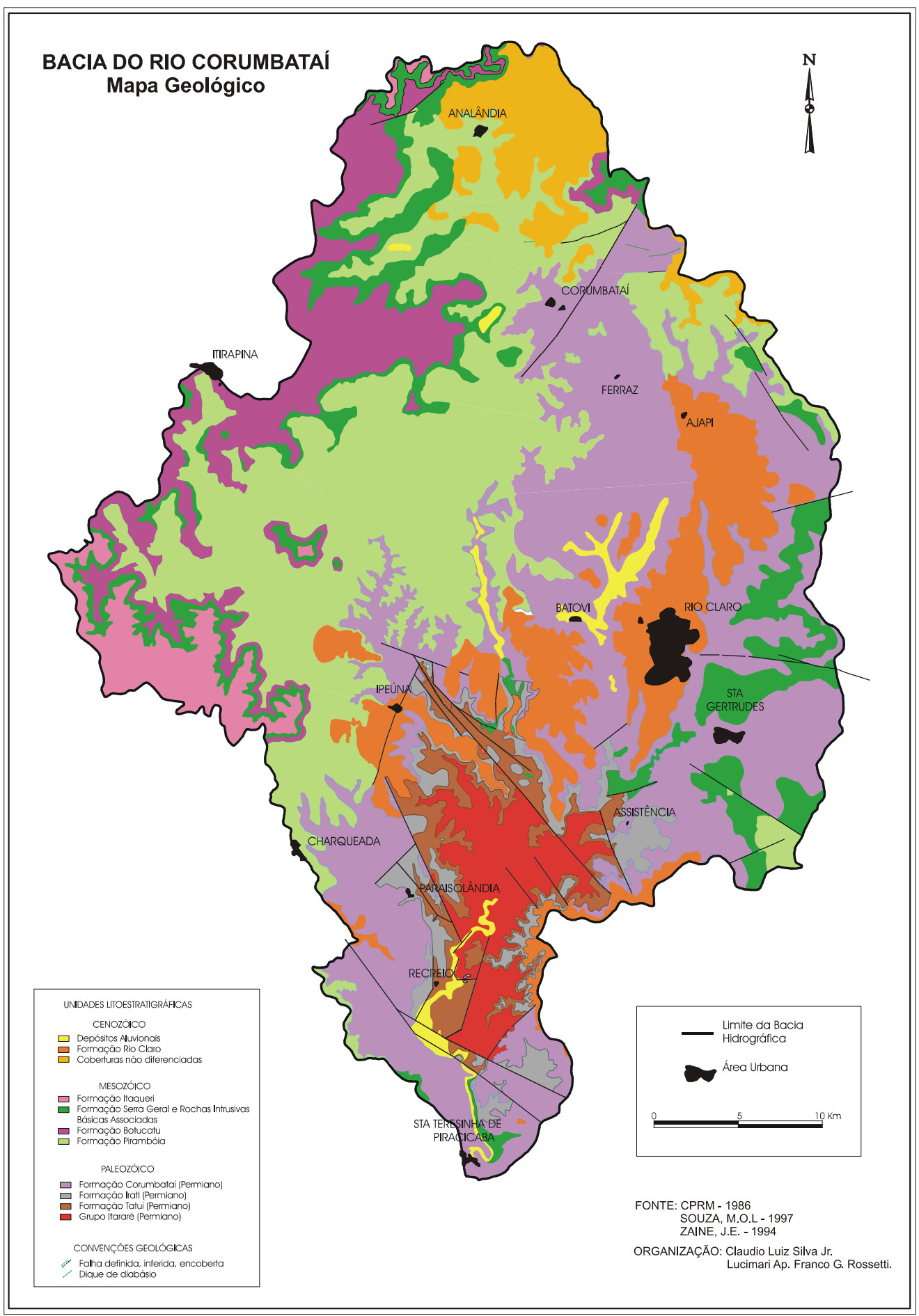

Figura 2 - Mapa geológico da bacia do Rio Corumbataí

Fonte: CEAPLA (2005). Disponível em http://www.rc.unesp.br/igce/ceapla/ biblioteca/download.html) 
O modelo digital do terreno (MDT) para a bacia, destacando aspectos geográficos e políticos, é apresentado na Figura 3.

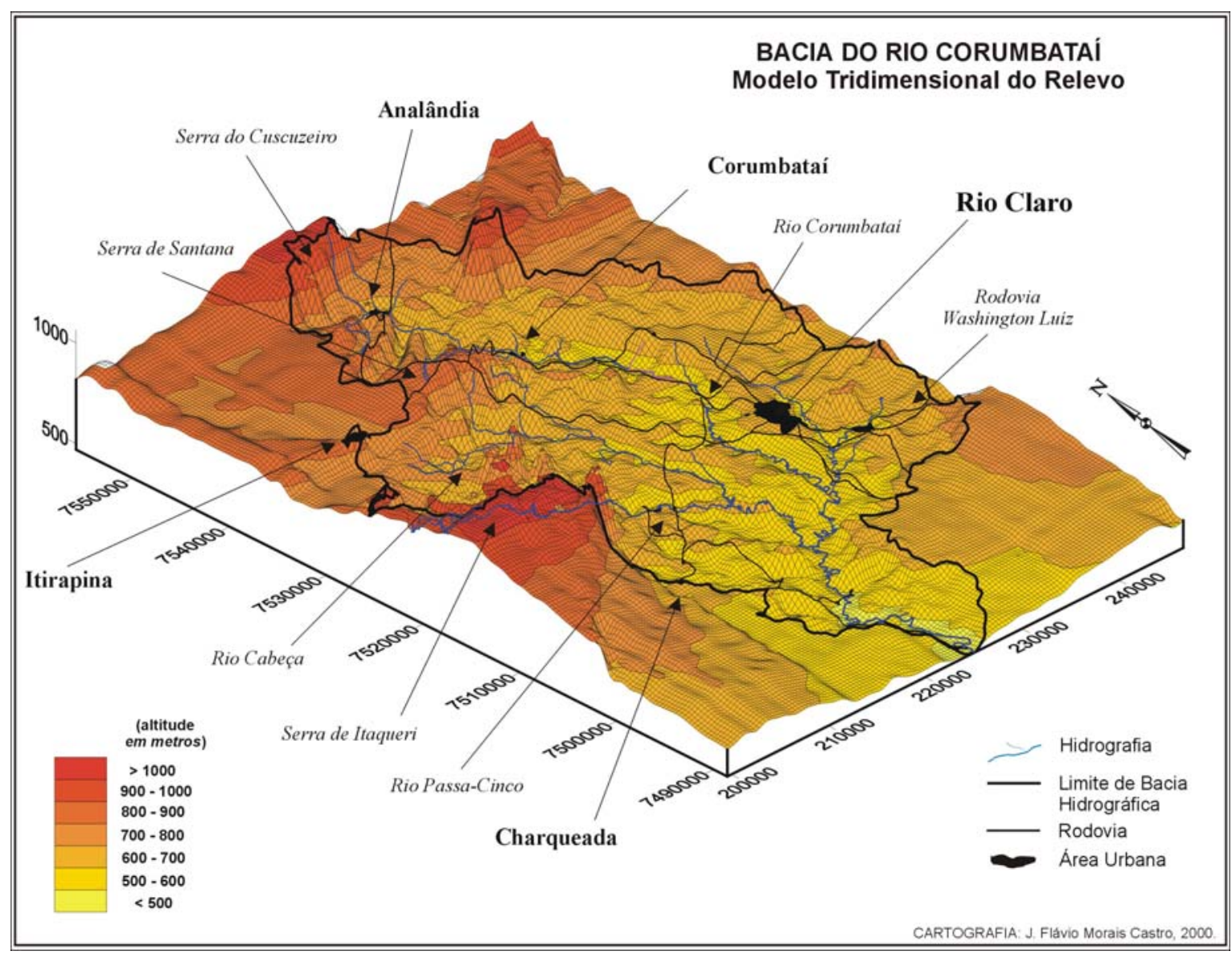

Figura 3 - Modelo digital do terreno para a bacia do Rio Corumbataí

Fonte: CEAPLA (2005). Disponível em http://www.rc.unesp.br/igce/ceapla/ biblioteca/download.html

\subsubsection{Solos}

Os solos predominantes na bacia são os Podzólicos Vermelho-Amarelos $(43,46 \%)$ e os Latossolos Vermelho-Amarelos (21,58\%), como pode ser observado na Figura 4 e na Tabela 1. 


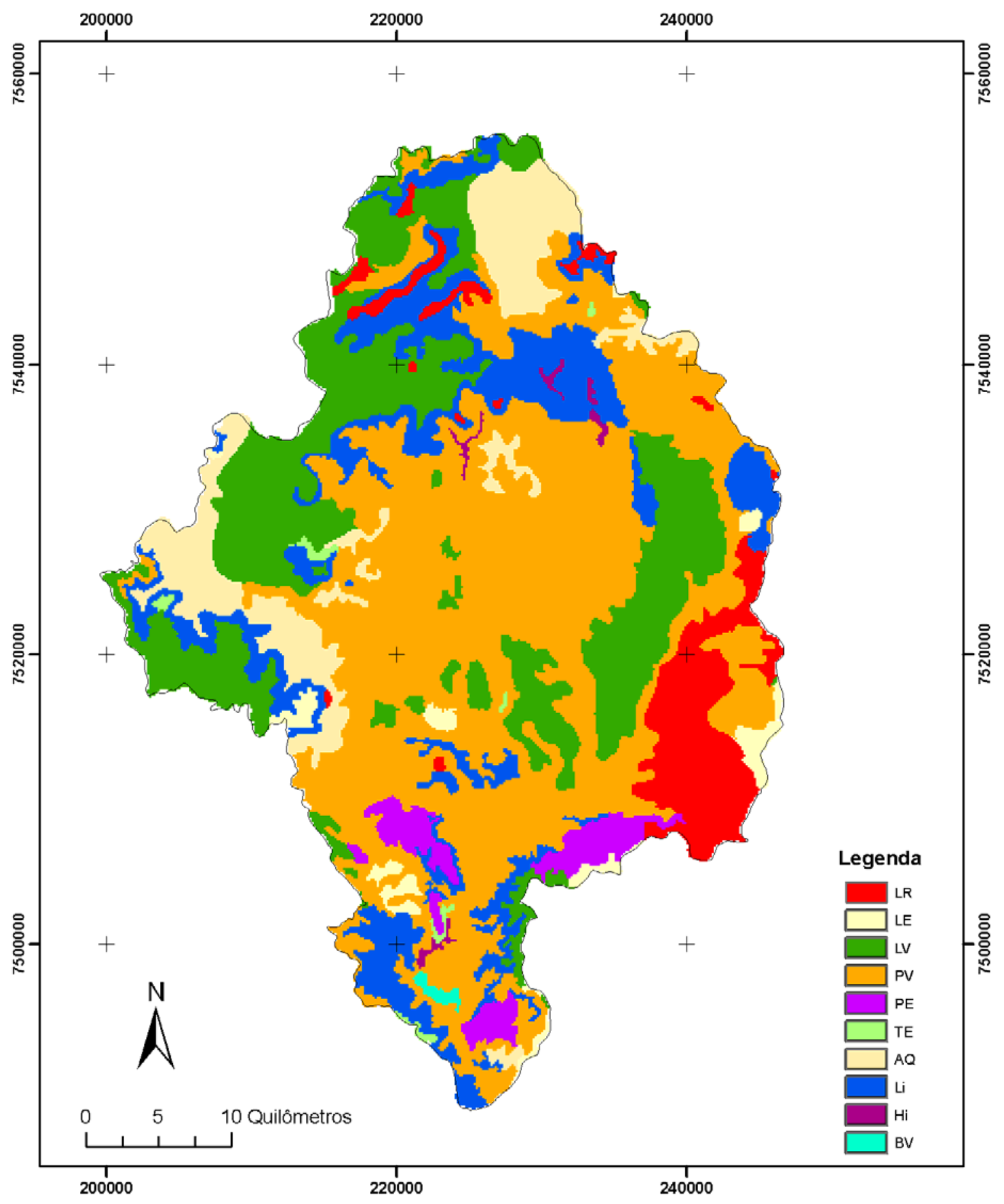

Figura 4 - Classes de solo presentes na bacia do Rio Corumbataí Fonte: IPEF (2001) 
Tabela 1 - Classes de solo presentes na bacia do Rio Corumbataí

Fonte: IPEF (2001).

\begin{tabular}{ccc}
\hline Classe de Solo & Área \\
& (ha) & (\%) \\
\hline Podzólico Vermelho-Amarelo (PV) & $74.219,07$ & 43,46 \\
Latossolo Vermelho-Amarelo (LV) & $36.853,37$ & 21,58 \\
Litólico (Li) & $23.601,19$ & 13,82 \\
Areia Quartzosa (AQ) & $15.130,72$ & 8,86 \\
Latossolo Roxo (LR) & $11.476,12$ & 6,72 \\
Podzólico Vermelho-Escuro (PE) & $4.764,64$ & 2,79 \\
Latossolo Vermelho-Escuro (LE) & $3.039,81$ & 1,78 \\
Terra Roxa Estruturada (TE) & 700,18 & 0,41 \\
Solos Hidromórficos (Hi) & 683,10 & 0,40 \\
Brunizem Avermelhado (BV) & 307,40 & 0,18 \\
\hline Total & $170.775,60$ & 100,00 \\
\hline
\end{tabular}

De acordo com Oliveira (1999), os Latossolos são solos minerais, não hidromórficos, com horizonte $B$ latossólico precedido de qualquer tipo de horizonte $A$ diagnóstico. Em nível categórico mais baixo, na área de estudo são encontrados os Latossolos Roxos, os Latossolos Vermelho-Escuros e os Latossolos VermelhoAmarelos.

Os Latossolos Roxos são solos não hidromórficos, com horizonte B latossólico de coloração vermelho-escuro-acinzentada a bruno-avermelhado-escura, precedido de qualquer tipo de horizonte $A$ diagnóstico. Relacionam-se a conteúdos elevados de $\mathrm{Fe}_{2} \mathrm{O}_{3}(18 \%$ a 40\%), forte atração magnética e índice $\mathrm{Ki}$ 0,2 a 2,0. Em virtude de elevados teores de magnetita e hematita revelam, quando secos e pulverizados, forte atração pelo imã. Emprega-se tal atributo no campo para diferenciá-los dos Latossolos Vermelho-Escuros, aos quais se assemelham bastante. São em geral muito profundos, atingindo vários metros de espessura. Os Latossolos Vermelho-Amarelos apresentam teor de $\mathrm{Fe}_{2} \mathrm{O}_{3}$ na TFSA proveniente do ataque sulfúrico inferior a $9 \mathrm{~g} / \mathrm{kg}$ quando argilosos, ou com relação molecular $\mathrm{Al}_{2} \mathrm{O}_{3} / \mathrm{Fe}_{2} \mathrm{O}_{3}$ superior a 3,14 quando de textura 
média e horizonte B com matiz mais amarelo que 3,5YR. São solos muito profundos ou profundos, com granulometria variada e diferentes tipos de horizonte $A$, fato levado em consideração para discriminá-los em níveis categóricos mais baixos.

Os Podzólicos Vermelho-Amarelos são solos não hidromórficos, com distinta individualidade de horizontes, decorrente de acentuada diferença em textura, cor ou estrutura. Apresentam horizonte $B$ textural e a seguinte seqüência de horizontes: $A, E$ (pode faltar), Bt e C. Normalmente a transição entre os horizontes $A$ ou $E$ (quando existente) e o Bt é abrupta ou clara e, em geral, apresentam um gradiente textural elevado, acima de 1,5. Quando o gradiente textural é pouco expressivo, o horizonte $\mathrm{Bt}$ deve apresentar estrutura e cerosidade no mínimo moderada. As cores do horizonte $\mathrm{Bt}$ vão desde a vermelha até a amarela e o teor de $\mathrm{Fe}_{2} \mathrm{O}_{3}$ extraível pelo ácido sulfúrico é inferior a $11 \mathrm{~g} / \mathrm{kg}$ nos amarelos e a $15 \mathrm{~g} / \mathrm{kg}$ nos vermelhos.

Os Podzólicos Vermelho-Escuros abrangem parte desmembrada dos Podzólicos Vermelho-Amarelos e englobam a extinta Terra Roxa Estruturada Similar. São solos minerais, não hidromórficos, com horizonte B textural de cores avermelhadas, usualmente de matiz mais vermelho que $5 \mathrm{YR}$ e com valor inferior a 5 e croma menor que 7 e com teores de $\mathrm{Fe}_{2} \mathrm{O}_{3}$ inferiores a $15 \mathrm{~g} / \mathrm{kg}$, o que os distingue das Terras Roxas Estruturadas. Os Podzólicos Vermelho-Escuros podem apresentar diversos tipos de horizonte $A$, desde que sejam satisfeitas algumas condições: (1) se o A for chernozêmico, o horizonte $\mathrm{Bt}$ deve ser de argila de atividade baixa; (2) se o A for proeminente ou húmico, o horizonte $\mathrm{Bt}$ deve ser de argila de atividade baixa e os teores de alumínio baixos (adotou-se em caráter preliminar o valor $\mathrm{Al}^{3+}$ igual ou inferior a 10 $\mathrm{mmolc} / \mathrm{dm}^{3}$ de TFSA).

As Terras Roxas Estruturadas são solos minerais, não hidromórficos, argilosos a muito argilosos, com fraca relação textural, teores relativamente elevados de $\mathrm{Fe}_{2} \mathrm{O}_{3}$, iguais ou superiores a $15 \mathrm{~g} / \mathrm{kg}$ ao longo do perfil e horizonte $\mathrm{B}$ textural bem desenvolvido quanto à estrutura e cerosidade, apresentando coloração mais vermelha que 3,5YR e argila de atividade baixa.

Os Brunizens Avermelhados são solos minerais, não hidromórficos, eutróficos, com horizonte A chernozêmico seguido de horizonte $B$ textural com argila de atividade alta e de coloração avermelhada. 
As Areias Quartzosas são solos desenvolvidos sobre material de origem arenosa, apresentando perfil constituído por um horizonte $A$ fraco, moderado ou proeminente, assentado sobre um material inconsolidado, pouco diferenciado. A fração areia, representada essencialmente pelo quartzo, é igual ou superior a $70 \mathrm{~g} / \mathrm{kg}$ e a fração argila, inferior a $15 \mathrm{~g} / \mathrm{kg}$. Os minerais primários intemperizáveis são virtualmente inexistentes, ou presentes em quantidades muito reduzidas (<3\%).

Solos Litólicos são solos pouco evoluídos, rasos ( $<50 \mathrm{~cm}$ de espessura), com horizonte $A$ assentado diretamente sobre a rocha coerente e dura $(A, R)$ ou cascalheira espessa, ou sobre horizonte $C$ pouco espesso ( $A, C, R)$. Apresentam grande variabilidade espacial de atributos, tais como CTC, tipo de horizonte $A$ e textura.

Sob a denominação Solos Hidromórficos foram incluídos os Glei Pouco Úmicos e os Glei Húmicos. Ambos apresentam horizonte glei (não simultâneo com horizonte $B$ textural) em seqüência ao horizonte $A$ moderado nos Glei Pouco Húmicos e ao horizonte turfoso ou A proeminente nos Glei Húmicos. Tais solos ocorrem em áreas alagadiças, em geral de difícil acesso, e apresentam grande variabilidade espacial em muitos de seus atributos.

Com base na primeira ordem do Novo Sistema de Classificação de Solos Brasileiros (EMBRAPA, 1999), os solos apresentados anteriormente enquadram-se nas seguintes ordens: Latossolos (LR, LE e LV); Argissolos (PV e PE); Nitossolos (TE); Neossolos (AQ e Li); Gleissolos (Hi) e Chernossolos (BV). Assim, a bacia do Rio Corumbataí apresenta $46,21 \%$ de sua área constituída por Argissolos; 30,14\% por Latossolos; $22,66 \%$ por Neossolos; $0,41 \%$ por Nitossolos; $0,40 \%$ por Gleissolos; e $0,18 \%$ por Chernossolos (Figura 5 ). 


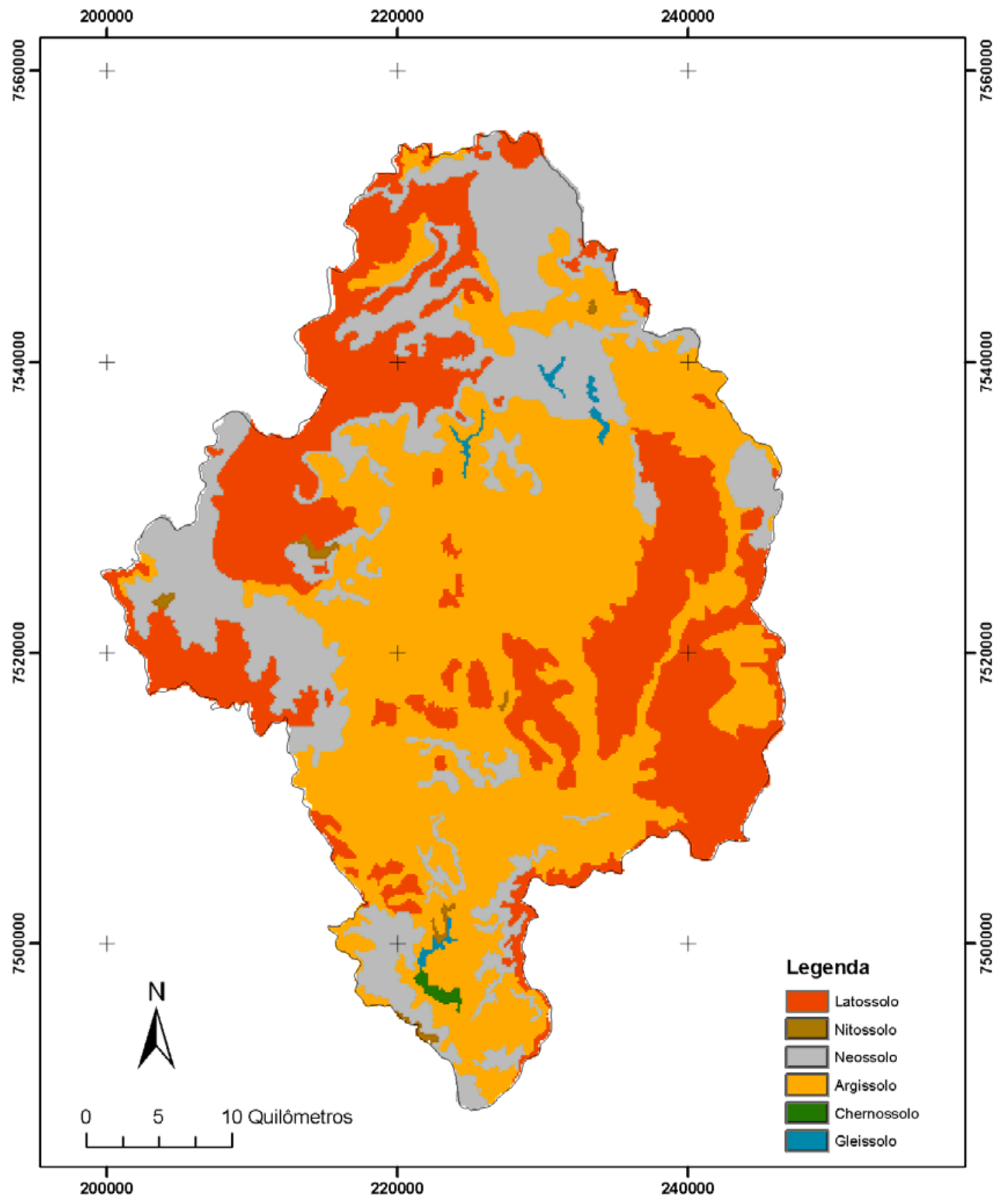

Figura 5 - Ordens de solo presentes da bacia do Rio Corumbataí, segundo o Novo Sistema de Classificação de Solos Brasileiros (EMBRAPA, 1999)

Fonte: Valente (2005). Adaptado (reclassificado) de Oliveira et al. (1989), Oliveira; Prado e Almeida (1981a) e Oliveira et al. (1981b). 


\subsubsection{Uso e cobertura do solo}

Para o melhor entendimento do uso e cobertura do solo atuais na bacia do Rio Corumbataí, é apresentado, a seguir, um breve histórico da ocupação da região, relatado por Garcia (2000).

De acordo com a autora, as primeiras notícias que se têm sobre a região remontam aos princípios do século XVIII, quando por ela passavam forasteiros e viajantes, rumo ao interior ("sertão"), então desconhecido. No entanto, o povoamento e a ocupação só se efetivaram com a expansão das fazendas de criação de gado e o desenvolvimento da lavoura canavieira, a partir do final do século XVIII.

O impulso definitivo ao desenvolvimento dessa região foi dado com a doação de sesmarias, principalmente nas primeiras décadas do século XIX, acompanhada da introdução da cultura da cana-de-açúcar, promovendo o efetivo povoamento da região.

A cultura da cana foi encorajada pelas autoridades reais já por volta de 1750 , principalmente na região de Itu. Nas duas décadas seguintes a cultura estendeu-se para a região de Campinas e, de lá, para Piracicaba. Na região de Rio Claro cultivou-se a cana nas três primeiras décadas do século XIX e, embora não tendo perdurado por muito tempo, agiu como um importante fator de povoamento e colonização.

A cana prosperava em Itu, Parnaíba e Piracicaba, enquanto que em Campinas e Rio Claro ia gradativamente cedendo espaço para a cultura do café, cuja expansão, a partir década de 1850, veio a dinamizar o povoamento e serviu também para acarretar profundas mudanças nas relações de trabalho, principalmente no que se refere ao emprego do trabalhador imigrante europeu, em substituição ao braço escravo. Também contribuiu para a introdução do regime de parceria, que mais tarde muito contribuiria para a multiplicação da pequena propriedade e da agricultura em pequena escala (familiar).

Com o café vieram as ferrovias, dada a necessidade de transporte do produto ao Porto de Santos, de onde era exportado. As ferrovias tiveram importante papel na ocupação da região, com diversas cidades nascendo ao redor das estações. Além disso, com as ferrovias deu-se a ampliação e a diversificação das atividades econômicas na região, com a instalação de serrarias, cerâmicas, beneficiadoras de 
grãos, armazéns, oficinas etc. Portanto, pode-se dizer que as cidades da bacia do Corumbataí, que passaram a ser servidas pela Companhia Paulista de Estrada de Ferro, foram cidades que "nasceram com o café".

Nas três primeiras décadas do século $X X$ o café foi gradativamente perdendo a sua importância em área ocupada nos municípios da bacia, mas foi o grande responsável pela infra-estrutura aí instalada, à semelhança do que ocorria em outras regiões do Estado de São Paulo.

A crise do café, em 1929, afetou profundamente a agricultura da região, que apenas na década de 1940, lentamente, começou a se reorganizar, com base na pequena produção e na policultura, sem atingir a antiga lucratividade, nem mesmo com a ascensão da produção canavieira na década de 1950. Essa situação de estagnação sofreu um processo de reversão na década de 1970, quando a industrialização no município de Rio Claro integra-se a processos que ocorrem em níveis mundial, nacional e regional, ou seja, a internacionalização do sistema industrial capitalista e também a desconcentração espacial da indústria em território paulista.

Na região de Rio Claro o café foi paulatinamente perdendo expressão e sendo substituído pela cana-de-açúcar e pela pecuária. Em 1970 a área cultivada com café diminuiu em mais de 60\%, tendência essa que perdurou na década de 1980, ao passo que a citricultura teve sua área dobrada. A cultura canavieira tomou o lugar de outras culturas no período 1950/1960, tendo sua área dobrada na década de 1970, com os incentivos do Pró-Álcool. Culturas de menor expressão, como arroz, feijão e milho, eram cultivadas apenas em pequenas propriedades, perdendo área gradativamente para a cultura da cana-de-açúcar. A pecuária passou a ocupar também destaque na região, principalmente ao norte de Rio Claro, porém com um nível tecnológico em geral baixo (pequenos produtores de gado leiteiro).

É de se destacar também a região de Rio Claro como um dos primeiros núcleos de reflorestamento com eucalipto, no país, para atender à demanda por madeira da Companhia Paulista de Estrada de Ferro.

A extração de minerais (calcário e argila) também foi e é importante para algumas regiões da bacia, notadamente com a indústria cerâmica de Santa Gertrudes. 
Com relação à cobertura vegetal original, a região era coberta basicamente por florestas e cerrado, este principalmente nas porções superiores da bacia. Rodrigues (1999) destaca, para a região, cinco tipos de formação florestal: Floresta Estacional Semidecidual (Mata de Planalto); Floresta Ripária (Mata Ciliar); Floresta Paludosa (Mata de Brejo); Floresta Estacional Decidual (Mata Seca) e Cerrado, com diversas fisionomias. Para a finalidade deste trabalho, os diversos tipos florestais presentes na bacia foram enquadrados em uma categoria única, denominada floresta (ou mata) nativa.

Um dos impactos ambientais negativos mais evidentes na bacia, resultante do processo de ocupação humana, tem sido a eliminação, ao longo do tempo, da maior parte de sua cobertura florestal original. Atualmente a cobertura florestal da bacia encontra-se intensamente fragmentada e degradada.

Uma das conseqüências marcantes do processo de expansão da atividade agrícola é a fragmentação dos ecossistemas naturais. No caso das florestas tropicais, a fragmentação dos ecossistemas resulta numa série de ameaças à conservação da biodiversidade regional, bem como à conservação dos recursos hídricos (IPEF, 2001). Em mapeamento recente do uso e cobertura do solo (Figura 6), Valente (2005) constatou que na bacia existe uma predominância do uso agrícola, com aproximadamente $42 \%$ de sua área ocupada por pastagem e $28 \%$ por cana-de-açúcar (Tabela 2). A pastagem distribui-se predominantemente nas porções superior e média da bacia, enquanto que a cana-de-açúcar nas partes média e baixa. A floresta nativa e o cerrado correspondem a, respectivamente, apenas $11,0 \%$ e $0,7 \%$ da área da bacia, sendo que as maiores manchas de vegetação florestal estão associadas às regiões com predomínio de pastagem. Ainda de acordo com Valente (2005), na bacia existem 3438 fragmentos de floresta nativa, sendo 2036 fragmentos com área menor que 1 ha, e apenas 156 fragmentos de cerrado, dos quais 72 com área menor que 1 ha. 


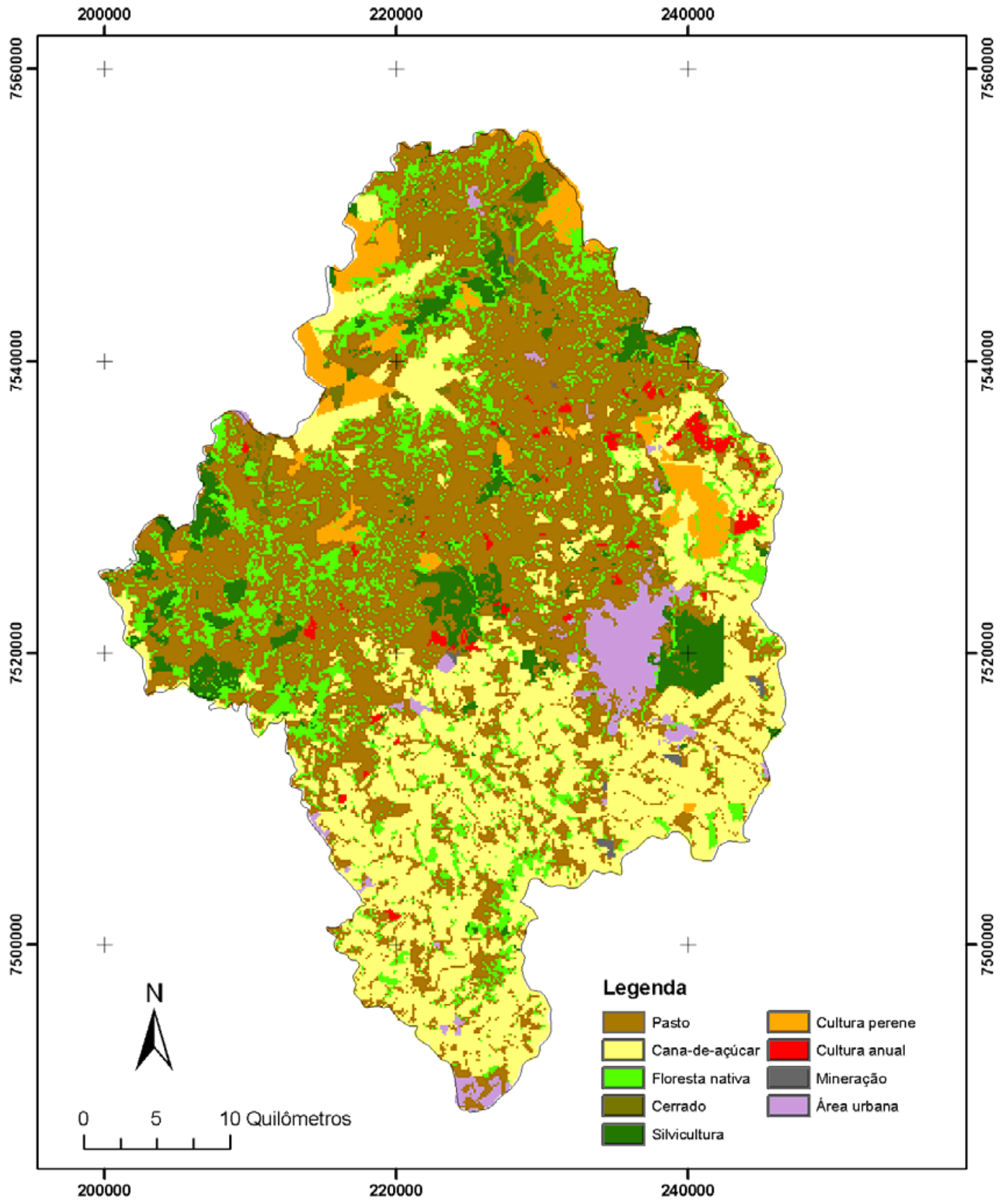

Figura 6 - Uso e cobertura do solo da bacia do Rio Corumbataí em 2003 Fonte: Valente (2005) 
Tabela 2 - Uso e cobertura do solo da bacia do Rio Corumbataí em 2003

\begin{tabular}{ccc}
\hline Classes de uso e cobertura do solo & Área & $(\%)$ \\
\hline Pastagem & $72.228,48$ & 42,29 \\
Cana-de-açúcar & $47.431,92$ & 27,77 \\
Floresta nativa & $19.234,84$ & 11,26 \\
Cerrado & $1.217,20$ & 0,71 \\
Floresta plantada & $9.713,84$ & 5,69 \\
Fruticultura & $6.848,80$ & 4,01 \\
Cultura anual & $1.575,48$ & 0,92 \\
Mineração & 323,92 & 0,19 \\
Área urbana & $4.937,72$ & 2,89 \\
Outros & $7.263,40$ & 4,25 \\
\hline Total & $170.775,60$ & 100,00 \\
\hline
\end{tabular}

* Área ocupada pela rede hidrográfica e pela malha viária Fonte: Valente (2005)

Valente e Vettorazzi (2003), com base no mapa de uso e cobertura do solo produzido para o ano de 2000, citam que as sub-bacias do Passa-Cinco e do Alto Corumbataí concentram as maiores áreas de floresta nativa e também os melhores fragmentos da bacia (maiores, mais próximos uns dos outros e com melhor forma). Os autores ressaltam ainda que o cerrado ocorre predominantemente nessas duas subbacias, com alguns poucos fragmentos na sub-bacia do Ribeirão Claro.

\subsubsection{Hidrografia}

O Rio Corumbataí é um tributário da margem direita do Rio Piracicaba, sendo seus principais afluentes os rios Passa-Cinco, Cabeça e o Ribeirão Claro. Nasce na Serra do Cuscuzeiro, município de Analândia, a aproximadamente 1040 m de altitude, e após percorrer ao redor de 110 km, deságua no Rio Piracicaba, no perímetro urbano do município de Piracicaba, a aproximadamente $460 \mathrm{~m}$ de altitude. 
A bacia do Rio Corumbataí é, em diversos estudos, tradicionalmente dividida nas seguintes sub-bacias: Alto Corumbataí (31.801,66 ha); Passa-Cinco (52.757,60 ha); Médio Corumbataí (29.316,60 ha); Ribeirão Claro (28.174,90 ha); e Baixo Corumbataí (28.724,84 ha) (Figura 7).

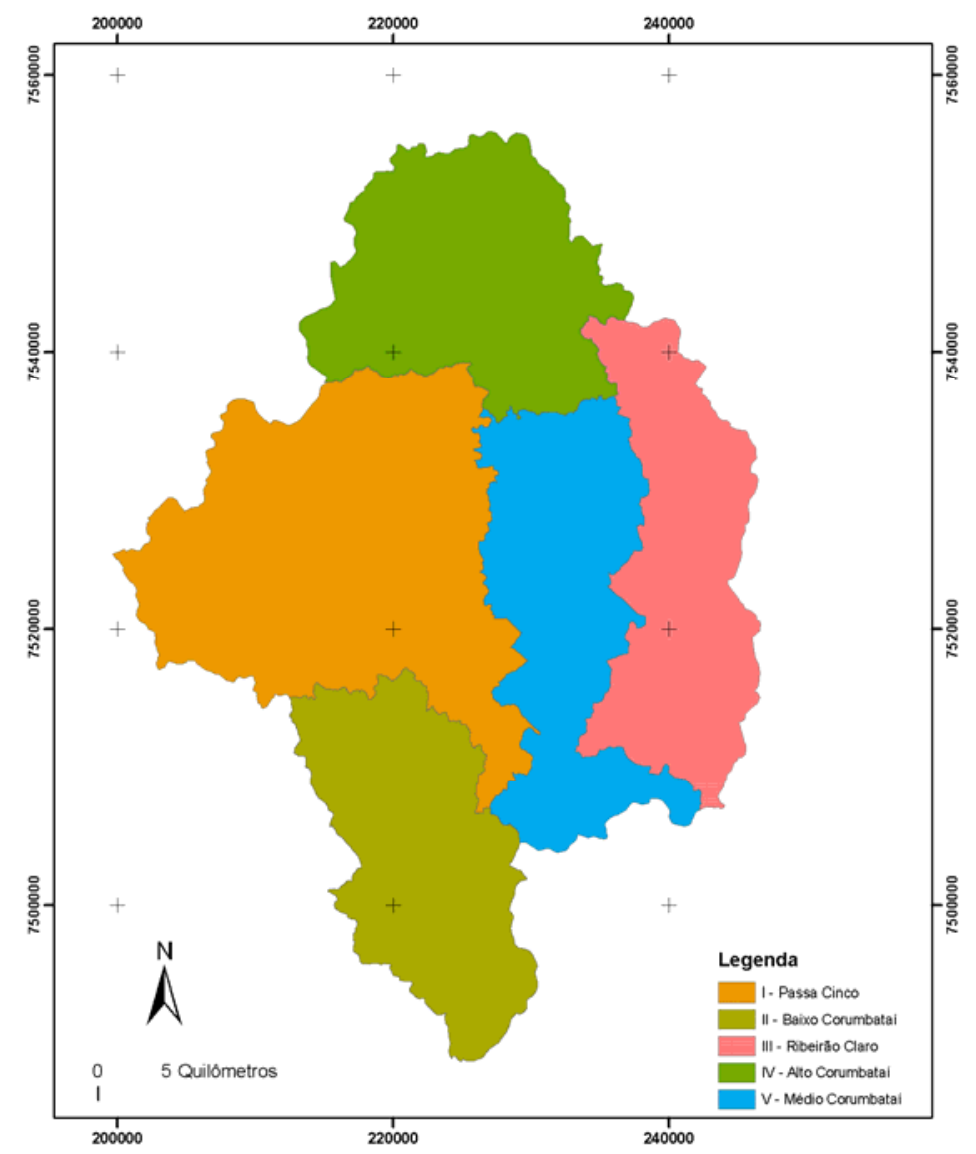

Figura 7 - Sub-bacias que compõem a bacia do Rio Corumbataí Fonte: IPEF (2001)

A vazão média anual do Rio Corumbataí, calculada para o período 1973-1997, no posto de monitoramento 4D-021, localizado na ponte da Usina Tamandupá, distrito de Recreio, foi de $25 \mathrm{~m}^{3} . \mathrm{s}^{-1}$ (SALATI, 1996).

Segundo Troppmair (1992), no seu alto curso o Rio Corumbataí apresenta forte declividade e escoamento rápido, intercalado por corredeiras e cachoeiras. Apesar do pequeno volume de água sobre um fundo rochoso, há forte processo erosivo, que se 
expressa por vales bem encaixados. $\mathrm{O}$ alto curso abrange $\mathrm{o}$ trecho entre a nascente e $\mathrm{o}$ distrito de Ferraz, num total de $35 \mathrm{~km}$, com declividade média de $7 \mathrm{~m} / \mathrm{km}$. No médio curso a declividade é menos acentuada (média de $2,5 \mathrm{~m} / \mathrm{km}$ ) e a velocidade da água menor, com o rio descrevendo curvas onde se depositam sedimentos trazidos do alto curso. O trecho abrange $40 \mathrm{~km}$, entre o distrito de Ferraz e a Hidrelétrica da CESP, em Rio Claro. No baixo curso, próximo à confluência com o Rio Piracicaba, o Rio Corumbataí é volumoso, descrevendo curvas e meandros sobre um substrato sedimentar, com uma declividade média de $1 \mathrm{~m} / \mathrm{km}$.

A rede de drenagem da bacia (Figura 8) apresenta, em geral, padrão dendrítico, mas podem ser visualizadas áreas distintas em termos de densidade de drenagem. A região do Alto Corumbataí, junto aos municípios de Analândia e Corumbataí, é bastante dissecada, o mesmo ocorrendo com certas áreas da sub-bacia do Rio Passa-Cinco. Nas regiões do Médio Corumbataí, na sub-bacia do Ribeirão Claro, junto aos municípios de Rio Claro e Santa Gertrudes, ocorre o oposto, ou seja, áreas pobremente dissecadas, com baixa densidade de drenagem (GERHARD, 2005).

A bacia do Rio Piracicaba drena uma das mais desenvolvidas regiões brasileiras, não só em termos agrícolas como industriais. Este desenvolvimento, no entanto, tem como contrapartida inúmeros problemas ambientais, destacando-se aqueles que afetam a água (MORETTI, 2000).

Dentre as sub-bacias da bacia do Rio Piracicaba, a do Rio Corumbataí configurase hoje como a mais importante do ponto de vista hídrico. Desde o início de 2000 toda a água consumida pela cidade de Piracicaba é bombeada deste rio e a maior preocupação, hoje, é a carga poluente, principalmente esgoto doméstico, liberado no rio na altura da cidade de Rio Claro (MORETTI, 2000).

Qualidade da água é um termo relativo, que varia de acordo com o uso desejado. A poluição da água é definida como algum prejuízo das propriedades desta, que adversamente afeta o homem como organismo vivo, ou indiretamente, através da alteração nos valores de seus constituintes físicos ou propriedades ou, ainda, na oportunidade de recreação ou apreciação da natureza (PALMA-SILVA, 1999). 


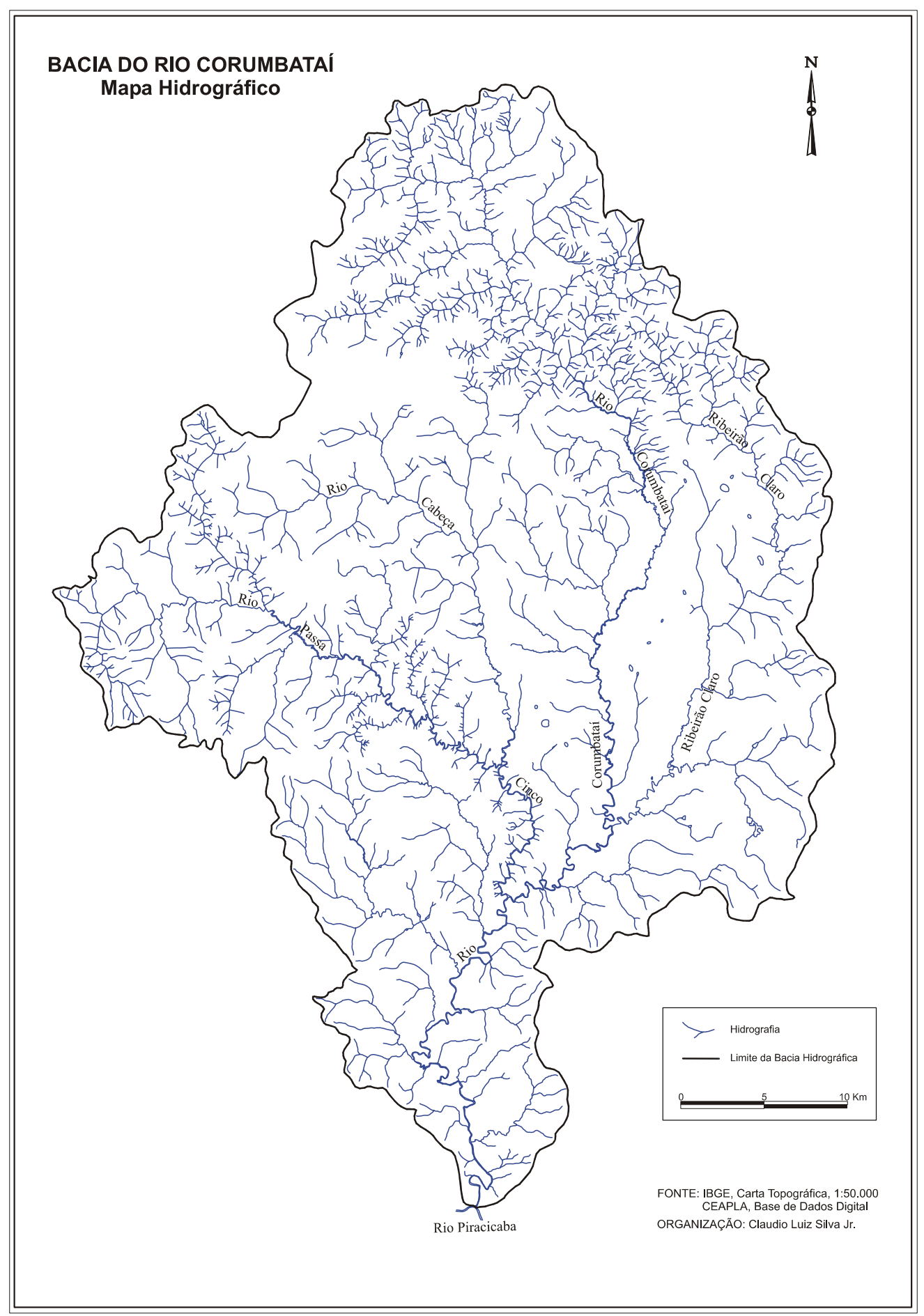

Figura 8 - Rede de drenagem da bacia do Rio Corumbataí

Fonte: CEAPLA (2005). Disponível em http://www.rc.unesp.br/igce/ceapla/ biblioteca/download.html) 
Dentre os fenômenos mais freqüentes que interferem na qualidade da água destacam-se: a erosão; os deslizamentos de encostas; os assoreamentos de cursos d'água; as inundações; o lançamento indiscriminado de detritos gerados pela ocupação urbana, incluindo lixo, efluentes sanitários, entulho e detritos industriais. Acrescente-se ainda o carreamento de fertilizantes e outros produtos empregados na agricultura e a lixiviação de nutrientes do solo, como contribuintes para a mudança da qualidade das águas, provocando a eutrofização do sistema aquático.

Moretti (2000) cita que, com relação à qualidade da água, de Analândia até Rio Claro o Rio Corumbataí é enquadrado como Classe 2; após receber os esgotos de Rio Claro, passa para a Classe 4 . Como a partir dessa região o rio vai se tornando meândrico, aumenta o seu poder de depuração, de modo que pouco abaixo passa para Classe 3 e, em seguida, Classe 2. Vale esclarecer que a Classe 2 é aquela em que é possível um tratamento adequado da água para consumo humano.

O Plano Diretor para a Conservação dos Recursos Hídricos por Meio da Recuperação e da Conservação da Cobertura Florestal da Bacia do Rio Corumbataí (IPEF, 2001) apresenta um cenário geral de aspectos hidrológicos da bacia.

De acordo com o referido Plano Diretor, considerando-se uma demanda total de água na bacia de $4,027 \mathrm{~m}^{3} \cdot \mathrm{s}^{-1}$ e uma vazão mínima para que os processos ecológicos que ocorrem no curso d'água não sejam afetados, de 4,65 $\mathrm{m}^{3} \cdot \mathrm{s}^{-1}$, analisando-se apenas as vazões médias diárias poder-se-ia pensar que a situação do Rio Corumbataí, como manancial de abastecimento de água para a cidade de Piracicaba, é cômoda, uma vez que a vazão diária para o mês mais seco (agosto) é de 10,85 $\mathrm{m}^{3} \cdot \mathrm{s}^{-1}$ (Posto Recreio, 1973-1994, dados do DAEE). No entanto, a análise do comportamento das vazões médias diárias ao longo dos anos, para o mês de agosto, demonstra uma tendência de queda. A mesma análise, considerando todos os meses do ano, demonstra a mesma tendência de diminuição da vazão do Rio Corumbataí.

Com relação à qualidade da água, tomando-se a turbidez como indicador, uma vez que é esta variável que determina a quantidade de produtos químicos a serem utilizados no tratamento da água, os estudos realizados para a elaboração do Plano Diretor, com os dados do período 1991-1995, indicam uma tendência de aumento no valor daquele indicador. 
Assim, o Plano conclui que é certo afirmar que a situação dos recursos hídricos na bacia do Rio Corumbataí é preocupante, uma vez que a tendência da vazão é de diminuir e a da turbidez de aumentar, ou seja, se não houver mudança nesse contexto ocorrerá escassez de água de boa qualidade para abastecimento público na bacia.

\subsubsection{Base de dados cartográficos}

Os dados cartográficos empregados no presente trabalho foram, em sua grande maioria, provenientes da base de dados sobre a bacia do Rio Corumbataí, desenvolvida no Laboratório de Geoprocessamento do Departamento de Engenharia Rural da Escola Superior de Agricultura "Luiz de Queiroz", da Universidade de São Paulo, em Piracicaba, SP. Vários dados empregados no trabalho foram gerados por ocasião da elaboração do Plano Diretor para a Conservação dos Recursos Hídricos por Meio da Recuperação e da Conservação da Cobertura Florestal da Bacia do Rio Corumbataí (IPEF, 2001), no qual o Laboratório tomou parte, na coordenação. Também foram utilizados dados provenientes de trabalhos mais recentes, desenvolvidos no Laboratório.

Os planos de informação empregados neste trabalho, todos com resolução espacial de $20 \mathrm{~m}$, sistema de coordenadas UTM e datum Córrego Alegre, estão apresentados nas Figuras 9A e 9B e descritos a seguir.

\subsubsection{Uso e cobertura do solo}

Este plano de informação refere-se ao uso e cobertura do solo na bacia, para o ano de 2003, gerado por Valente (2005), numa atualização do mapa referente a 2000, produzido por Valente e Vettorazzi (2003).

O mapa de uso e cobertura do solo da bacia (Figura 9A-a) foi produzido a partir da classificação supervisionada (Método da Máxima Verossimilhança) de imagens Landsat-7, sensor ETM+, referentes à passagem de 17 de agosto de 2002, com verificações de campo em 2003. 


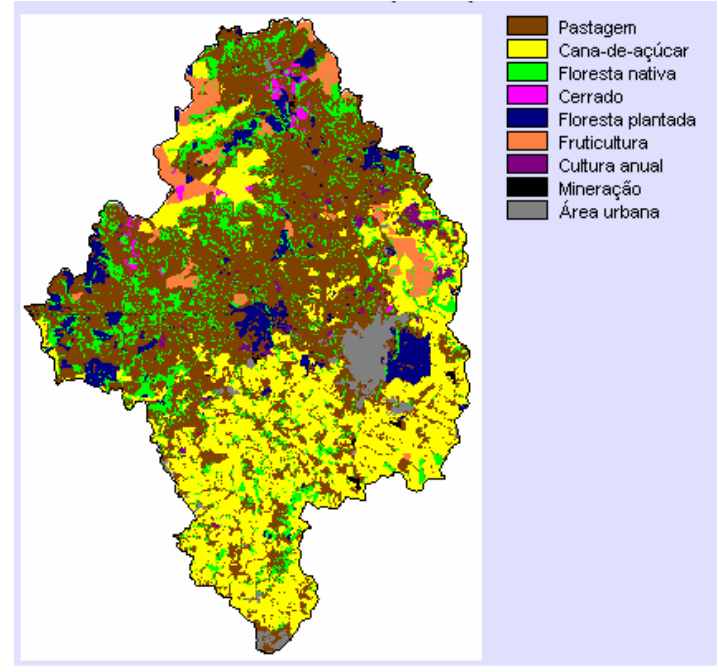

(a)

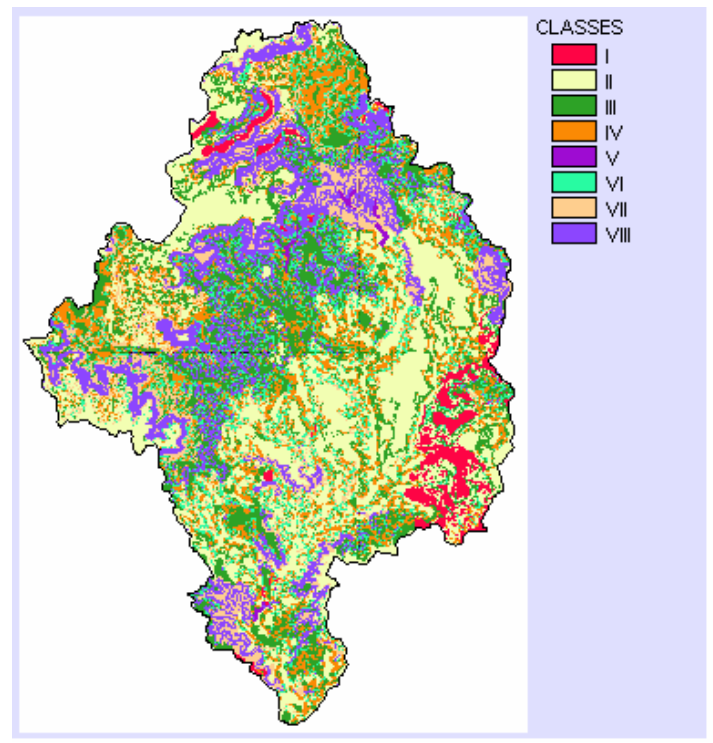

(c)

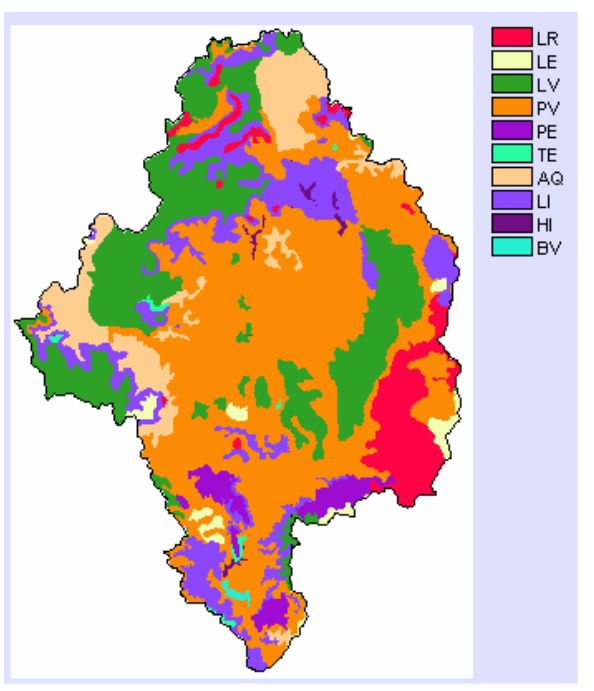

(b)

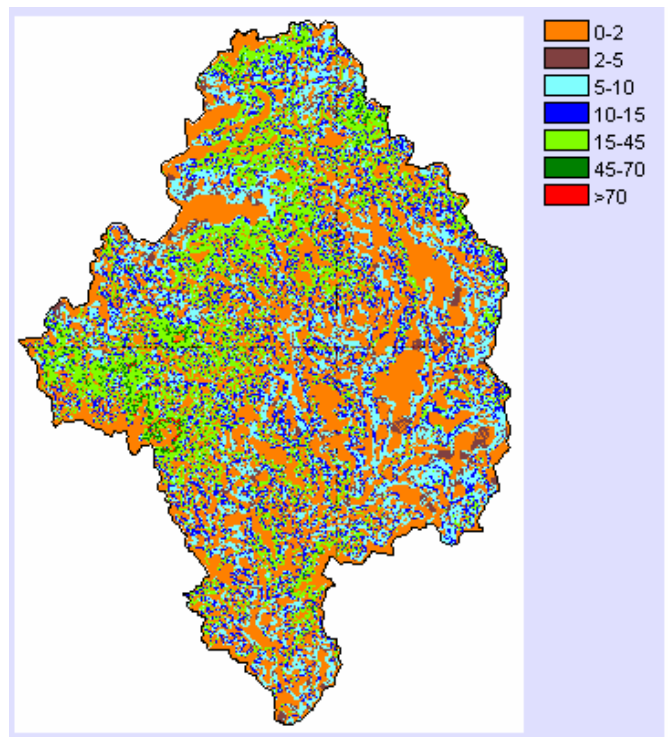

(d)

Figura 9A - Planos de informação para a bacia do Rio Corumbataí, empregados na Avaliação Multicritérios: (a) uso e cobertura do solo; (b) solos; (c) classes de capacidade de uso da terra; e (d) classes de declividade 


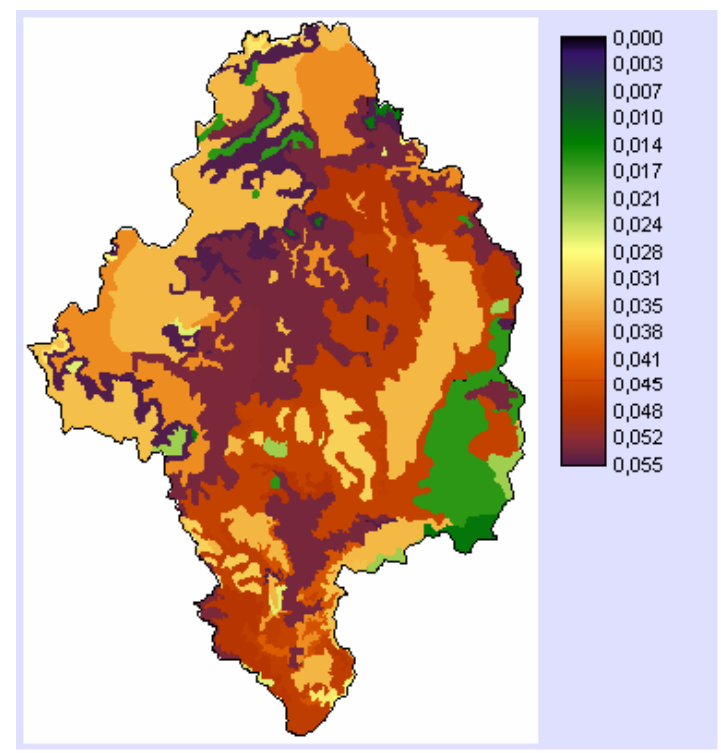

(e)

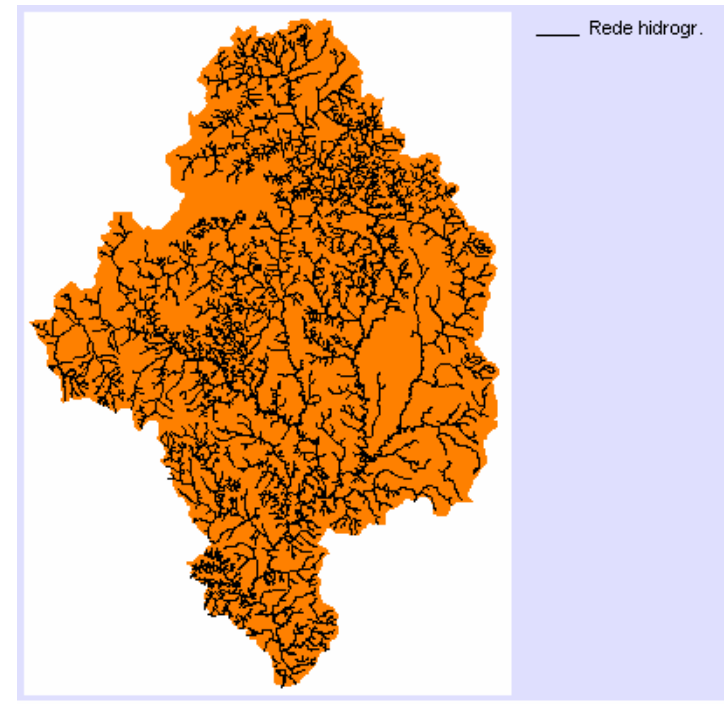

(g)

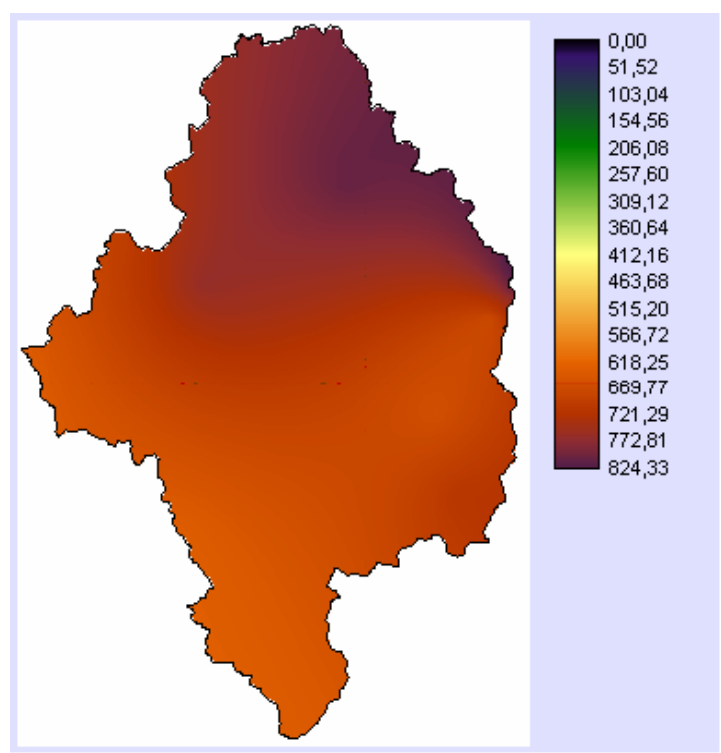

$(f)$

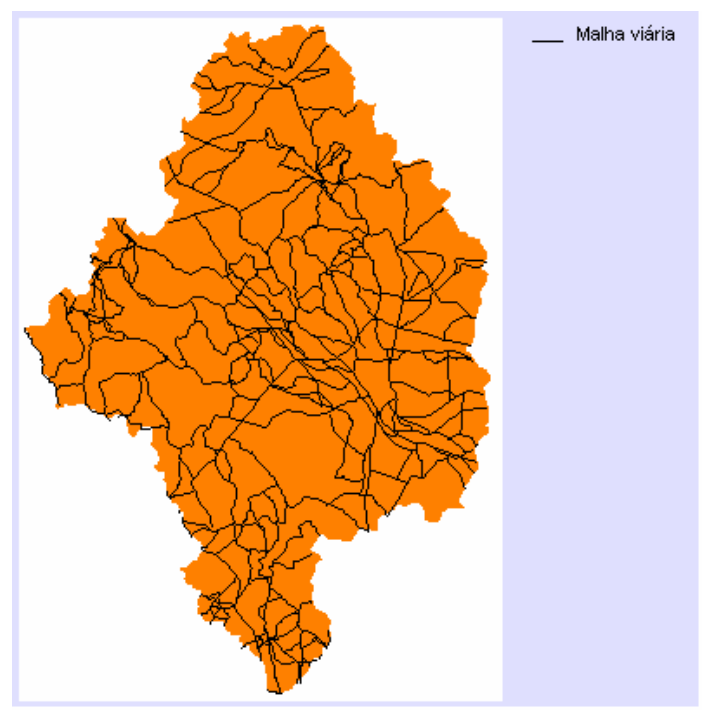

(h)

Figura 9B - Planos de informação para a bacia do Rio Corumbataí, empregados na Avaliação Multicritérios: (e) erodibilidade do solo; (f) erosividade da chuva; (g) rede hidrográfica; e (h) malha viária 
A exatidão global de classificação para esse mapa foi de 92,96\%, com um índice Kappa (K) global de concordância de 0,97 (VALENTE, 2005). Esse valor de exatidão foi superior ao considerado como mínimo aceitável (85\%), por Anderson et al. (1979), para classificações realizadas sobre imagens orbitais de média resolução espacial.

Qualitativamente, segundo os critérios apresentados por Landis e Koch (1977) para emprego do índice Kappa, a classificação foi enquadrada como excelente.

A resolução espacial do mapa de uso e cobertura do solo foi reamostrada para 20 m, para a sua compatibilização com os demais planos de informação, provenientes do banco de dados do Projeto Corumbataí (IPEF, 2001).

\subsubsection{Solos}

O plano de informação referente aos solos da bacia do Rio Corumbataí (Figura 9A-b)) foi elaborado a partir da digitalização e posterior concatenação e "recorte" para a bacia, dos mapas do Levantamento Pedológico Semidetalhado do Estado de São Paulo, na escala 1:100.000, quadrículas de Piracicaba (OLIVEIRA et al., 1989), São Carlos (OLIVEIRA; PRADO; ALMEIDA, 1981a) e Araras (OLIVEIRA et al., 1981b).

\subsubsection{Classes de capacidade de uso da terra}

O plano de informação referente às classes de capacidade de uso da terra foi gerado de acordo com as diretrizes contidas na Quarta Aproximação do Manual Brasileiro para Levantamento da Capacidade de Uso da Terra (LEPSCH, 1983).

De uma forma sintética, as classes de capacidade de uso podem ser assim caracterizadas:

Grupo A (terras passíveis de utilização com culturas anuais, perenes e/ou reflorestamento e vida silvestre)

Classe I: terras cultiváveis, aparentemente sem problemas especiais de conservação.

Classe II: terras cultiváveis, com problemas simples de conservação. 
Classe III: terras cultiváveis, com problemas complexos de conservação.

Classe IV: terras cultiváveis apenas ocasionalmente ou em extensão limitada, com sérios problemas de conservação.

Grupo B (terras impróprias para cultivos intensivos, mas ainda adaptadas para pastagens e/ou reflorestamento e/ou vida silvestre, porém cultiváveis em casos de algumas culturas especiais protetoras do solo)

Classe V: terras adaptadas em geral para pastagens e/ou reflorestamento, sem necessidade de práticas especiais de conservação, cultiváveis apenas em casos muito especiais.

Classe VI: terras adaptadas em geral para pastagens e/ou reflorestamento, com problemas simples de conservação, cultiváveis apenas em casos especiais de algumas culturas permanentes protetoras do solo.

Classe VII: terras adaptadas em geral somente para pastagens ou reflorestamento, com problemas complexos de conservação.

Grupo C (apresenta apenas a Classe VIII)

Classe VIII: terras não adequadas para cultivos anuais, perenes, pastagens ou reflorestamento, porém apropriadas para proteção da flora e da fauna silvestres, recreação ou armazenamento de água.

$\mathrm{Na}$ geração do plano classes de capacidade de uso da terra (Figura 9A-c) foram empregados o mapa de solos da bacia, o mapa de classes de declividade e as informações do Levantamento Pedológico Semidetalhado do Estado de São Paulo (escala 1:100.000).

\subsubsection{Declividade do terreno}

O plano de informação declividade do terreno (Figura 9A-d) foi produzido a partir do recorte, para a área de estudo, do modelo digital do terreno gerado para o Projeto PiraCena (PROJETO PIRACENA, 2000) e incorporado ao banco de dados da bacia do 
Rio Corumbataí, do Laboratório de Geoprocessamento do Departamento de Engenharia Rural da ESALQ/USP.

A partir do modelo foi gerado o mapa de declividade, em porcentagem, que, posteriormente, foi reclassificado em sete categorias, conforme Lepsch (1983), ou seja: 0-2\%; 2-5\%; 5-10\%; 10-15\%; 15-45\%; 45-70\%; e acima de 70\%.

\subsubsection{Erodibilidade do solo}

Esse plano de informação (Figura 9B-e) foi obtido a partir da reclassificação do mapa de solos, sendo que cada classe de solo foi associada ao valor correspondente de erodibilidade. A erodibilidade do solo tem seu valor quantitativo determinado experimentalmente em parcelas unitárias, sendo expresso como a perda de solo por unidade de índice de erosão da chuva, tendo por unidade t.ha.h.ha ${ }^{-1} \cdot \mathrm{MJ}^{-1} \cdot \mathrm{mm}^{-1}$ (BERTONI; LOMBARDI NETO, 1985).

\subsubsection{Erosividade da chuva}

Os valores de erosividade da chuva forma calculados empregando-se a metodologia proposta por Lombardi Neto e Moldenhauer (1980), a partir dos dados de estações pluviométricas localizadas dentro e nas proximidades da área de estudo. Esses dados são disponibilizados pelo CENA/USP, via Internet (PROJETO PIRACENA, 2000). Os valores pontuais de erosividade, em MJ.mm.ha ${ }^{-1} \cdot h^{-1}$.ano ${ }^{-1}$, foram interpolados pelo método da krigagem, na geração do mapa da variável para a bacia (Figura 9B-f).

\subsubsection{Rede hidrográfica}

O plano rede hidrográfica (Figura 9B-g) foi gerado a partir da digitalização (via mesa digitalizadora) dos cursos d'água e represas, de cartas topográficas do IBGE, na escala 1:50.000, e complementado pela digitalização em tela (cursos d'água de ordens menores e represas construídas após a edição dos mapas), tendo como base imagens 
dos satélites SPOT e Landsat (as mesmas empregadas na geração do plano uso e cobertura do solo).

\subsubsection{Malha viária}

De forma análoga à geração do plano rede hidrográfica, o plano de informação malha viária (Figura 9B-h) foi digitalizado de cartas topográficas do IBGE, na escala 1:50.000, e complementado/atualizado via digitalização em tela sobre imagens orbitais. Constam do plano, tanto as estradas principais (estaduais e intermunicipais) quanto as secundárias (vicinais), asfaltadas ou não.

\subsubsection{Software}

O software empregado na Avaliação Multicritérios para o mapeamento das áreas prioritárias foi o Idrisi Kilimanjaro (EASTMAN, 2003). O Idrisi consiste de um programa principal, contendo o menu e a barra de ferramentas, que faz a interface com mais de 200 módulos específicos, cobrindo os principais campos de utilização envolvendo análises espaciais (SIG) e sensoriamento remoto. Neste trabalho, o módulo utilizado nas principais análises foi o de Apoio à Decisão.

\subsection{Métodos}

Antes do detalhamento dos passos metodológicos empregados na pesquisa, será apresentada, com a intenção de promover um melhor entendimento da abordagem utilizada, uma fundamentação teórica envolvendo conceitos e métodos presentes neste trabalho. Essa fundamentação tem por base, essencialmente, os textos de Malczewski (1999, 2004), Jiang e Eastman (2000) e Eastman (2001). 


\subsubsection{Fundamentação teórica}

\subsubsection{Análise estratégica de decisão}

Devido principalmente ao rápido crescimento populacional, as pressões sobre o uso de recursos naturais têm-se tornado intensas e a tarefa de gerenciamento desses recursos, pelos profissionais envolvidos, tem sido particularmente difícil. A alocação de terras para obras de engenharia, reflorestamento, agricultura, conservação, recreação etc. é um dos problemas mais usuais que os profissionais da área ambiental enfrentam atualmente. Restrições de ordem ambiental, financeira, social e cultural, por exemplo, podem reduzir as alternativas de modo significativo e o processo de tomada de decisão torna-se dominado por incertezas e, conseqüentemente, riscos, para os tomadores de decisão.

Nos últimos anos, um interesse considerável tem sido focado no uso do SIG como um sistema de apoio à decisão, notadamente na área de alocação de recursos.

Segundo Eastman (2001), a Teoria de Decisão trata da lógica pela qual se chega a uma escolha entre alternativas. O que são essas alternativas, varia de problema a problema. Elas podem ser ações alternativas, hipóteses alternativas sobre um fenômeno, objetivos alternativos e assim por diante. No contexto do SIG, é útil distinguir-se entre decisões políticas e decisões sobre alocação de recursos. A última envolve decisões que afetam diretamente a utilização de recursos (por exemplo, terra) enquanto a primeira somente pretende influenciar o comportamento decisório de terceiros que, por sua vez, irão fazer o comprometimento dos recursos. O SIG possui um potencial considerável em ambas as áreas.

No contexto de decisões políticas, o SIG é mais comumente utilizado para informar o tomador de decisão. Entretanto, ele também tem potencial como um instrumento de modelagem de processos, com o qual os efeitos espaciais do comportamento previsto da decisão podem ser simulados.

Decisões sobre alocação de recursos são também excelentes candidatas à análise por meio de SIG. Na verdade, a avaliação e a alocação de terras são das atividades mais importantes no gerenciamento de recursos. Com o emprego de um 
SIG, há a oportunidade para um processo de avaliação de terras explicitamente mais racional. Entretanto, há necessidade de um constante desenvolvimento de procedimentos e instrumentos para a aplicação de regras de decisão e modelagem preditiva, para que esse potencial do SIG seja efetivamente aproveitado.

\subsubsection{Definições}

Embora haja uma literatura razoavelmente extensa sobre tomada de decisão nos mais variados campos de aplicação, há, infelizmente, um uso algumas vezes até divergente da terminologia. Assim, julgou-se interessante apresentar, a seguir, algumas definições importantes no contexto da tomada de decisão em ambiente SIG, compiladas por Eastman (2001).

\subsection{Decisão}

Uma decisão é uma escolha entre alternativas. As alternativas podem representar diferentes cursos de ação, diferentes hipóteses sobre o caráter de uma feição, diferentes classificações e assim por diante. Esse conjunto de alternativas é chamado de quadro decisório (decision frame). No contexto do SIG, a decisão pode ser considerada o ato de designar um indivíduo (no caso, cada pixel de um dado mapa) a um conjunto de decisão (decision set), que reúne todos os indivíduos aos quais é assinalada uma alternativa específica do quadro decisório.

\subsection{Critério}

Um critério é alguma base para uma decisão, que pode ser medida e avaliada. É a evidência sobre a qual um indivíduo pode ser designado a um conjunto de decisão. Critérios podem ser de dois tipos: fatores e restrições e podem referir-se tanto a atributos do indivíduo como ao conjunto todo de decisão. 


\section{(A) Fator}

Um fator é um critério que realça ou diminui a adequação de uma alternativa específica para uma atividade em consideração. É, portanto, mais comumente medido em uma escala contínua. Fatores também são conhecidos por variáveis decisórias (decision variables), em programação matemática, e variáveis estruturais (structural variables), em programação linear.

\section{(B) Restrição}

Uma restrição serve para limitar as alternativas sob consideração. Em muitos casos, restrições podem ser expressas na forma de mapas booleanos (lógicos), com as áreas excluídas de consideração sendo codificadas com zero (0) e aquelas abertas à consideração codificadas com um (1). Entretanto, em alguns casos, a restrição pode ser expressa como alguma característica que o conjunto de decisão deve possuir. Por exemplo, pode ser requerido que o conjunto de decisão consista de uma única área contínua. Restrições como estas são freqüentemente chamadas de metas (goals) ou alvos (targets). De qualquer forma, ambos os tipos de restrição têm o mesmo significado: limitar as alternativas sob consideração.

\subsection{Regra de decisão}

O procedimento pelo qual os critérios são selecionados e combinados, para se chegar a uma avaliação em particular, e pelo qual as avaliações são comparadas, é conhecido como regra de decisão. Uma regra de decisão pode ser tão simples quanto um limiar aplicado a um critério único (tal como, todas as regiões com declividade menor que 35\% serão zoneadas como adequadas ao desenvolvimento) ou podem ser tão complexas como uma que envolva a comparação de diversas avaliações multicritérios. Regras de decisão tipicamente contêm procedimentos para combinar critérios em um simples índice composto e uma declaração de como as alternativas serão comparadas usando esse índice. 


\subsection{Objetivo}

Regras de decisão são estruturadas no contexto de um objetivo específico. A natureza desse objetivo e como ele é visto pelos tomadores de decisão (isto é, seus motivos) servirão como uma força-guia no desenvolvimento de uma regra de decisão específica. Um objetivo é, então, uma perspectiva que serve para guiar a estruturação de regras de decisão.

\subsection{Avaliação}

O processo de, efetivamente, aplicar-se a regra de decisão é chamado de avaliação.

(A) Avaliações Multicritérios

Para se atingir um objetivo específico, é freqüente o caso em que diversos critérios devem ser avaliados. Tal procedimento é chamado de Avaliação Multicritérios.

(B) Avaliações Multiobjetivos

Enquanto muitas das decisões a serem tomadas são induzidas por um único objetivo, também acontece de haver tomadas de decisão que devem satisfazer a vários objetivos. Um problema multiobjetivo é encontrado sempre que houver dois ou mais conjuntos de candidatos (conjuntos de entidades) e membros a partilhar. Os objetivos podem ser de natureza complementar ou conflitante

\subsection{Risco de decisão}

Risco de decisão pode ser entendido como a probabilidade de que a decisão tomada esteja errada. O risco resulta da incerteza e sua avaliação requer, assim, uma combinação de estimativas de incertezas das várias fontes envolvidas (incerteza na base de dados e na regra de decisão) e procedimentos. 


\subsection{Compensação}

A compensação entre fatores (trade-off) pode ser pensada como uma taxa de substituição, ou seja, o quanto de um fator que o tomador de decisão dispõe-se a abrir mão, em favor de uma "quantidade" especificada de algum outro fator.

\subsubsection{Visão geral dos métodos para análise de adequação do uso da terra baseados em SIG}

Malczewski (2004) menciona que as abordagens baseadas em SIG para análise da adequação do uso da terra têm suas raízes nas aplicações de técnicas de sobreposição (overlay) à mão, usadas por profissionais americanos no final do século XIX e início do século XX. O método é amplamente reconhecido como o precursor dos procedimentos clássicos de sobreposição em SIG. O autor cita, ainda, que é possível distinguir três grupos principais de abordagem à análise de adequação do uso da terra baseada em SIG: (1) sobreposição de mapas assistida por computador; (2) métodos de avaliação multicritérios; e (3) métodos de inteligência artificial.

\subsection{Sobreposição de mapas assistida por computador}

As técnicas de sobreposição de mapas assistidas por computador foram desenvolvidas em resposta às limitações do método manual de mapeamento e combinação de grandes bases de dados. Ao invés de mapear os valores de uma série de fatores de adequação em escalas de cinza ou de cores, os modelos são armazenados em forma numérica, como matrizes, no computador. Os mapas individuais de adequação podem então ser analisados e combinados para obter um mapa geral de adequação.

A introdução das técnicas de modelagem cartográfica e álgebra de mapas no mapeamento assistido por computador foi um importante avanço dos métodos de análise de adequação. A análise por sobreposição (overlay analysis) é fundamental à 
abordagem de álgebra de mapas para lidar com problemas de adequação de uso da terra.

\subsection{Métodos de tomada de decisão multicritérios}

A integração entre técnicas de Tomada de Decisão Multicritérios (TDMC) e SIG tem proporcionado um avanço considerável nas abordagens convencionais de análise de adequação de uso da terra por sobreposição de mapas. A TDMC em ambiente SIG pode ser pensada como um processo que combina e transforma dados espaciais e não-espaciais (entrada) em uma decisão resultante (saída). Os procedimentos (ou regras de decisão) de TDMC definem um relacionamento entre os mapas de entrada e o mapa de saída. Os procedimentos envolvem a utilização de dados geográficos, as preferências dos tomadores de decisão e o tratamento dos dados e preferências de acordo com regras de decisão especificadas. Conseqüentemente, duas considerações são de importância crítica para a TDMC espacial: (i) as capacidades do SIG de aquisição, armazenamento, recuperação, manipulação e análise de dados; e (ii) as capacidades da TDMC de combinar os dados geográficos e as preferências do tomador de decisão em valores unidimensionais de decisões alternativas. Uma série de regras de decisão tem sido implementada em ambiente SIG para abordar a questão da adequação de uso do solo. As regras de decisão podem ser classificadas em multiobjetivos e multicritérios (multiatributos). As abordagens multiobjetivos são métodos orientados a modelos de programação matemática, enquanto que os métodos de tomada de decisão multicritérios são orientados a dados.

\section{(A) Métodos multiobjetivos}

Métodos multiobjetivos definem um conjunto de alternativas, em termos de um modelo de decisão consistindo de duas ou mais funções objetivo e um conjunto de decisões impostas às variáveis de decisão. O modelo implicitamente define as alternativas em termos de variáveis de decisão. Os modelos multiobjetivos são geralmente empregados convertendo-os a modelos de único objetivo e então resolvendo o problema pelo uso de métodos padrões de programação linear. Alguns 
autores têm demonstrado o potencial da integração da programação linear como uma ferramenta para análise de adequação do uso da terra baseada em SIG. Eles mostram como a programação linear pode ser usada para otimizar o padrão espacial de uso da terra, gerar diferentes cenários de planejamento e analisar as relações entre variáveis de decisão e restrições do problema.

A complexidade computacional é uma das razões pelas quais os métodos de otimização multiobjetivos são difíceis de implementar em ambiente SIG. Requerem um esforço considerável em termos de desenvolvimento de algoritmos de programação matemática ou de integração de pacotes de otimização disponíveis no mercado e SIG. As abordagens multicritérios são muito mais fáceis de implementar em SIG (especialmente para o modelo de dados raster). Conseqüentemente, há um número considerável de aplicações multicritérios em ambiente SIG para análise de adequação de uso da terra.

(B) Métodos multicritérios

Na última década, ou pouco mais, vários métodos de avaliação multicritérios têm sido implementados em ambiente SIG, incluindo a Combinação Linear Ponderada (CLP) e suas variantes; Método do Ponto Ideal; Análise de Concordância; e Processo Hierárquico Analítico. Entre esses procedimentos, a CLP e as operações Booleanas de sobreposição, ou seja, a intersecção (AND) e a união (OR), são considerados os mais diretos e os mais freqüentemente empregados. A CLP (também conhecida por ponderação aditiva simples) é baseada no conceito de média ponderada. $O$ tomador de decisão assinala diretamente os pesos de "importância relativa" a cada mapa de atributo. Uma pontuação (escore) total é então obtida para cada alternativa, multiplicando-se o peso de importância assinalado para cada atributo pelo valor escalar dado à alternativa sobre aquele atributo e somando-se os produtos de todos os atributos. Quando os escores totais são calculados para todas as alternativas, a alternativa com o escore geral mais alto é escolhida. Esse método pode ser operacionalizado usando-se qualquer SIG que possua capacidade de sobreposição (overlay). As técnicas de sobreposição permitem que os mapas de critérios (mapas de entrada) sejam combinados de modo a determinar o mapa final (mapa de saída). Os 
métodos podem ser implementados tanto em ambientes SIG raster como vetoriais. Alguns SIGs possuem rotinas próprias para o método da CLP. Há, entretanto, algumas limitações fundamentais associadas ao uso desses procedimentos em um processo de tomada de decisão. Jiang e Eastman (2000) fazem uma discussão dessas limitações e sugerem que o método da Média Ponderada Ordenada (MPO) proporciona uma extensão e uma generalização dos métodos convencionais de combinação de mapas em SIG.

A MPO é uma classe de operadores multicritérios (YAGER, 1988). Ela envolve dois conjuntos de pesos: pesos de importância do critério (ou pesos de fatores) e pesos de ordenação. Um peso de importância é assinalado para cada critério (atributo) para todos os locais da área de estudo, para indicar sua importância relativa (de acordo com as preferências do tomador de decisão) em um conjunto de critérios sob consideração. Os pesos de ordenação estão associados com os valores dos critérios em uma base local-a-local (objeto-a-objeto). Eles são assinalados a um atributo de local, com valores em ordem decrescente, sem assinalar de que atributo o valor é proveniente. Os pesos de ordenação são essenciais aos procedimentos de combinação (agregação) no método da MPO. Eles são associados ao grau de ORness, que indica o grau ao qual um operador MPO é similar à conectiva lógica OR em termos de seu comportamento de combinação. O parâmetro é também associado com uma medida de compensação (trade-off), indicando o grau de compensação entre critérios. Os parâmetros associados com as operações MPO servem como um mecanismo para guiar a análise de adequação do uso da terra com base em um SIG. A medida ORness permite a interpretação dos resultados da MPO no contexto da teoria comportamental da tomada de decisão. As operações MPO tornam possível o desenvolvimento de uma variedade de estratégias de uso da terra, variando do pessimismo extremo (a estratégia do tipo "mínimo", baseada na combinação pela lógica AND), passando pela estratégia intermediária (neutra) em termos de risco (correspondendo à CLP convencional), até a estratégia extremamente otimista (a estratégia do tipo "máximo", baseada na combinação pela lógica OR). Desse modo, a MPO pode ser considerada como uma extensão e uma generalização dos procedimentos convencionais de combinação em um SIG. 
Outra técnica multicritérios, que tem sido incorporada aos procedimentos de análise de adequação em SIG, é a Análise Hierárquica Analítica (SAATY, 1980). Esse método pode ser usado de duas maneiras distintas em ambiente SIG. Primeiro, ela pode ser empregada para derivar os pesos associados aos mapas de critérios. Então, os pesos podem ser combinados com os mapas de critérios de modo similar aos métodos de combinação aditiva linear. Esta abordagem é de particular importância para problemas envolvendo um grande número de alternativas representadas por meio de dados matriciais (raster), quando é impossível executar uma comparação pareada das alternativas (EASTMAN; KYEM; TOLEDANO, 1993). Segundo, o princípio da AHA pode ser usado para agregar a prioridade para todos os níveis da estrutura hierárquica, incluindo o nível representando alternativas. Neste caso, um número relativamente pequeno de alternativas pode ser avaliado. Esta abordagem é também mais apropriada para implementação em SIGs vetoriais. Deve-se notar que a AHA pode ser usada como uma "ferramenta" de consenso em situações envolvendo a tomada de decisão por um comitê ou grupo. Apesar do uso abrangente da AHA, alguns pesquisadores questionam as funções teóricas do método.

Uma das dificuldades associadas aos métodos multicritérios é a questão da independência entre os atributos. O Método do Ponto Ideal evita algumas das dificuldades. Esta abordagem ordena um conjunto de alternativas com base na sua separação de um ponto ideal. Este ponto representa uma alternativa hipotética, que consiste dos níveis mais desejáveis de cada critério, através das alternativas sob consideração. A alternativa mais próxima ao ponto ideal é a melhor alternativa. A separação é medida em termos de uma métrica de distância. Uma gama ampla de regras de decisão podem ser desenvolvidas, que combinem as definições diferentes de medidas de separação. Embora o Método do Ponto Ideal possa ser implementado tanto em ambiente SIG raster como vetorial, a técnica é especialmente adequada aos SIGs raster.

Há diversos problemas associados à implementação de métodos de tomada de decisão multicritérios em ambiente SIG. Primeiro, é bem conhecido que os dados de entrada dos procedimentos de avaliação multicritérios em SIG têm as propriedades de inexatidão, imprecisão e ambigüidade. Apesar deste conhecimento, os métodos 
tipicamente assumem que os dados de entrada são precisos e exatos. Alguns esforços têm sido feitos para lidar com esse problema, combinando-se procedimentos multicritérios em SIG com análise de sensibilidade e análise de propagação de erros. Outra abordagem para lidar com a imprecisão e a ambigüidade dos dados de entrada (valores de atributos e preferências dos tomadores de decisão) é o uso de métodos de lógica fuzzy.

O segundo problema relaciona-se com a padronização de critérios não comensuráveis. Há muitos métodos diferentes de padronização que podem ser usados em avaliações multicritérios em SIG. Para esse fim é importante notar que diferentes métodos de padronização podem levar a diferentes padrões de adequação de uso da terra. A abordagem mais comum para padronização de critérios é o método da transformação linear. Entretanto, não há uma boa justificativa teórica e empírica para o uso deste método. Uma vez que os critérios de avaliação agem como medidas de proximidade da utilidade do tomador de decisão, os diferentes valores de critérios refletem diferentes níveis de utilidade para o tomador de decisão. Se os valores forem mudados ou distorcidos pelo processo de transformação, a estrutura de preferências intra e interatributos pode ser afetada.

Terceiro, dada a grande variedade de regras de TDMC, há uma questão sobre qual dos métodos é o melhor a ser usado em uma situação particular. Este é um problema não resolvido em análise de decisão. Diversos estudos demonstram que as diferentes regras de decisão geram padrões de adequação de uso da terra consideravelmente diferentes. Sugere-se que dois ou mais métodos devem ser aplicados para diluir o efeito do viés da técnica. Outra solução para esse problema é a integração entre TDMC e técnicas de Inteligência Artificial (IA), para desenvolver o suporte à decisão multicritérios "inteligente", ou baseada no conhecimento.

\subsection{Métodos de inteligência artificial}

Desenvolvimentos recentes em análise espacial mostram que a Inteligência Artificial (IA) oferece novas oportunidades à análise da adequação e ao planejamento de uso da terra. Definida de forma ampla, a IA inclui técnicas computacionais modernas 
que podem ajudar a modelar e descrever sistemas complexos para interferência e tomada de decisão. Sob esta perspectiva, a IA busca o desenvolvimento de sistemas que tentam imitar a inteligência humana sem exigir um entendimento dos processos básicos (fundamentais). O denominador comum desses métodos é que, diferentemente das abordagens convencionais, eles são tolerantes a imprecisão, ambigüidade, incerteza e verdade parcial. IA é um termo geral, cobrindo vários métodos, tais como os algoritmos evolucionários, programação genética, redes neurais artificiais, cellular automata e sistemas fuzzy. O termo geocomputação é algumas vezes usado para cobrir estas novas técnicas computacionais para análise e modelagem de dados geográficos e resolução de problemas espaciais. Áreas de pesquisa promissoras no desenvolvimento de sistemas híbridos incluem a integração entre SIG e abordagens de IA, tais como as técnicas de lógica fuzzy, redes neurais artificiais, algoritmos evolucionários (genéticos) e cellular automata.

\subsection{Considerações finais}

O desenvolvimento de métodos baseados em SIG para análise da adequação do uso da terra tem evoluído nos últimos trinta anos ou mais, a partir da modelagem por sobreposição de mapas, passando pelas técnicas de tomada de decisão multicritérios e caminhando para as várias abordagens da inteligência artificial. É importante notar que muitos estudos de caso empregam uma combinação desses métodos, p.ex. métodos de AMC podem ser usados em combinação com técnicas de IA. Adicionalmente, 0 modelo clássico de sobreposição (overlay) está presente, de um modo ou de outro, em muitos, se não todos, dos métodos. As abordagens clássicas de sobreposição de mapas e modelagem são os métodos mais comumente usados na análise da adequação de uso da terra em ambiente SIG. A maior limitação dessas abordagens é a falta de um mecanismo bem definido para incorporar valores de julgamento (p.ex. as preferências dos tomadores de decisão) aos procedimentos realizados no SIG. Esta limitação pode ser removida pela integração entre SIG e métodos de TDMC. A avaliação multicritérios não está, entretanto, totalmente livre de problemas. Os principais problemas estão relacionados à escolha do método para a combinação dos 
diferentes critérios de avaliação, padronização dos mapas de critérios e especificação dos pesos dos critérios. Diferentes métodos podem produzir diferentes resultados. Não há um método aceito de forma generalizada para assinalar pesos de importância relativa aos mapas de critérios. Novamente, é provável que diferentes métodos de ponderação resultem em diferentes padrões gerais de adequação de uso da terra. Alguns pesquisadores sugerem que esses problemas podem ser, pelo menos parcialmente, resolvidos pelo uso de métodos de IA. Entretanto, não há ainda um número suficiente de aplicações práticas usando métodos de IA para verificar sua utilidade ao lidar com problemas complexos de planejamento de uso da terra. A maior limitação desses métodos é seu estilo "caixa preta" de analisar problemas de natureza espacial.

\subsubsection{Método da Combinação Linear Ponderada}

Um dos métodos mais empregados na AMC é a Combinação Linear Ponderada (CLP) (VOOGD, 1983). Com a CLP, os fatores são combinados pela aplicação de um peso a cada um deles, seguida por uma soma dos resultados, para produzir um mapa de adequação (form. 1):

$$
S=\sum w_{i} X_{i}
$$

sendo:

$S$ a adequação; $w_{i}$ o peso do fator $i$; e $x_{i}$ o escore (de critério) do fator $i$.

Este procedimento é familiar em SIG e tem uma forma muito similar à natureza de uma equação de regressão. Em casos onde restrições booleanas são aplicadas, o procedimento é modificado multiplicando-se a adequação calculada a partir dos fatores pelo produto das restrições (form. 2): 


$$
S=\sum\left(w_{i .} X_{i}\right) * \prod c_{j}
$$

sendo:

$c_{j}$ o escore da restrição j e $\prod$ é o produto.

Todos os softwares de SIG possuem as rotinas básicas para a aplicação deste método. A questão básica, entretanto, reside na padronização dos escores dos critérios e a atribuição de pesos.

\section{Padronização dos escores dos critérios}

Devido às diferentes escalas utilizadas na mensuração dos critérios, é necessário que os fatores sejam padronizados, antes da combinação nas form. (1) ou (2), e que eles sejam transformados, se necessário, de tal maneira que todos os mapas de fatores sejam correlacionados positivamente com a adequação. Voogd (1983) revisou vários procedimentos de padronização, tipicamente usando os valores mínimos e máximos como referências na escala. O procedimento mais simples é a transformação linear (form. 3):

$$
\mathrm{X}_{\mathrm{i}}=\left(\mathrm{R}_{\mathrm{i}}-\mathrm{R}_{\min }\right) /\left(\mathrm{R}_{\max }-\mathrm{R}_{\min }\right) * \mathrm{~m}
$$

sendo:

R o escore (original) e m um multiplicador arbitrário.

Por meio da padronização, os escores de critérios serão expressos de acordo com uma escala numérica consistente (p.ex. 0-99, 0-255 etc.). No caso do Idrisi o módulo STRETCH pode ser usado para transformar linearmente todos os valores de 0 a 255, que é a variação total relativa a imagens de 8 bits. Assim, cada fator terá uma base de mensuração equivalente antes que os pesos sejam aplicados. 


\section{Pesos dos critérios}

Embora exista uma série de técnicas para a atribuição de pesos, uma das mais utilizadas tem sido a comparação pareada entre fatores, desenvolvida por Saaty (1977), no contexto de um processo de tomada de decisão conhecido como Análise Hierárquica Analítica (AHA).

No procedimento para AMC usando a CLP como já apresentada, é necessário que os pesos somem 1. Pela técnica desenvolvida por Saaty, pesos dessa natureza podem ser derivados tomando-se o vetor de autovalores (principal eigenvector) de uma matriz recíproca quadrada de comparações pareadas entre critérios. As comparações referem-se à importância relativa entre cada par de critérios envolvidos na determinação da adequação para um determinado objetivo. Os valores são derivados de uma escala contínua de nove pontos (Figura 10). Por exemplo, se o analista (ou grupo, na Técnica Participatória) conclui que proximidade a estradas é muito fortemente mais importante que declividade, na determinação da adequação para implantação industrial, ele entraria com o valor 7 na escala. No caso inverso (declividade é muito fortemente mais importante que proximidade a estradas), o analista entraria com o valor $1 / 7$.

\begin{tabular}{|c|c|c|c|c|c|c|c|c|}
\hline $1 / 9$ & $1 / 7$ & $1 / 5$ & $1 / 3$ & 1 & 3 & 5 & 7 & 9 \\
\hline $\begin{array}{c}\text { Extrema- } \\
\text { mente }\end{array}$ & $\begin{array}{c}\text { Muito } \\
\text { fortemente }\end{array}$ & Fortemente & $\begin{array}{c}\text { Moderada- } \\
\text { mente }\end{array}$ & Igualmente & $\begin{array}{c}\text { Moderada- } \\
\text { mente }\end{array}$ & Fortemente & $\begin{array}{c}\text { Muito } \\
\text { fortemente }\end{array}$ & $\begin{array}{c}\text { Extrema- } \\
\text { mente }\end{array}$ \\
\hline
\end{tabular}

Menos Importante

Mais Importante

Figura 10 - Escala contínua de nove pontos usada na comparação pareada entre fatores, na Avaliação Multicritérios

$\mathrm{Na}$ atribuição de pesos, um indivíduo, ou grupo, compara todos os possíveis pares e entra com os valores em uma matriz de comparação pareada. Uma vez que a matriz é simétrica, somente a metade triangular inferior necessita ser preenchida. As células remanescentes serão as recíprocas das preenchidas. É importante ressaltar 
que, se existir evidência empírica sobre a eficácia relativa de um par de fatores, essa evidência pode ser usada nessa etapa.

O procedimento requer então que o vetor de autovalores da matriz seja computado, para produzir o conjunto de pesos com o melhor ajuste. Não havendo, no software, um procedimento disponível para isto, uma boa aproximação pode ser obtida calculando-se os pesos com cada coluna e, então, tomando-se a média de todas as colunas. Assim, se tomarmos cada coluna de valores, na matriz de comparação pareada, fizermos a sua soma, dividirmos cada uma das entradas por essa soma, serão produzidos valores que, calculada a sua média para todas as colunas, se aproximam bastante dos pesos calculados pelo vetor de autovalores. No Idrisi, um módulo especial chamado WEIGHT foi desenvolvido para calcular os pesos dos critérios. Observar que os pesos devem somar 1, como é requerido pelo procedimento da CLP.

Devido ao fato de a matriz de comparação pareada apresentar múltiplos caminhos (ou maneiras) pelos quais a importância relativa dos critérios pode ser avaliada, é possível também determinar o grau de consistência atingido no desenvolvimento dos pesos. Saaty (1977) indica o procedimento pelo qual um índice de consistência, conhecido como Taxa de Consistência (TC), pode ser obtido. A TC indica a probabilidade de os valores da matriz terem sido gerados ao acaso (ou randomicamente). De acordo com o autor, as matrizes com TC maiores que 0,10 devem ser reavaliadas. Assim, o procedimento aceita os pesos quando a TC for menor que aquele limiar. Ao contrário, o procedimento WEIGHT analisa a matriz para determinar onde se encontram as inconsistências lógicas.

\section{Avaliação}

Uma vez que os mapas de critérios (fatores e restrições) tenham sido gerados, é uma simples questão de multiplicar cada mapa de fator (isto é, cada célula, ou pixel, de cada mapa) pelo seu peso, e então somar os resultados. Devido aos pesos terem de somar 1, o mapa de adequação resultante terá uma variação de valores como aqueles dos mapas de fatores padronizados que foram usados. Após todos os fatores terem sido incorporados, o mapa de adequação resultante é então multiplicado por cada uma 
das restrições, para eliminar as áreas não adequadas. No Idrisi, um módulo especial chamado MCE foi criado para empreender esses passos com a máxima eficiência.

\subsubsection{Método da Média Ponderada Ordenada}

O operador da Média Ponderada Ordenada (MPO) proporciona agregações (ou combinações) que residem entre os operadores booleanos de intersecção (MIN ou AND) e união (MAX ou OR), com a CLP exatamente entre os dois extremos. O conceito da Média Ponderada Ordenada foi introduzido por Yager (1988) e pode obter controle contínuo sobre o grau de ANDness e de ORness (sem tradução) do operador e o grau de compensação (trade-off) entre critérios. Na implementação de Yager, os critérios recebem pesos com base em sua ordem de ranqueamento em vez de suas qualidades inerentes. Por exemplo, podemos decidir aplicar pesos de 0,5, 0,3 e 0,2 a um conjunto de fatores $A, B$ e $C$, com base em sua ordem de ranqueamento. Se para um local os critérios fossem ranqueados BAC (do mais baixo para o mais alto), a combinação ponderada seria $0,5 B+0,3 A+0,2 C$. Entretanto, se para outro local os fatores fossem ranqueados $C B A$, a combinação ponderada seria $0,5 C+0,3 B+0,2 A$.

$\mathrm{Na}$ implementação do conceito de Yager (1988) por Eastman e Jiang (1996), citados por Jiang e Eastman (2000), foi retido o conceito de pesos que são aplicados a critérios específicos (fatores), como na CLP tradicional, produzindo dois conjuntos de pesos: pesos de critérios, aplicados a critérios específicos, e pesos de ordenação, aplicados aos critérios ranqueados, após a aplicação dos pesos de critérios. Na CLP tradicional, os pesos dos critérios determinam como os fatores se compensam entre si. Entretanto, o nível de compensação não é ajustável e é sempre assumida a compensação total. Na MPO, os pesos dos critérios são ajustados de acordo com o nível de compensação, de tal maneira que eles retêm sua significância total quando a compensação total é escolhida e gradualmente perdem seu significado (isto é, os pesos dos critérios tornam-se iguais) quando se aproxima da situação de não compensação. Enquanto os pesos de critérios estão associados com a importância (ou significância) relativa de um critério em particular para o conjunto de decisão, bem como a maneira como os critérios se compensam entre si, os pesos de ordenação controlam a posição 
do operador de agregação em um contínuo entre os extremos MIN (AND) e MAX (OR), bem como o grau de compensação.

São usados dois parâmetros, ANDness/ORness e Compensação (Trade-off), para caracterizar a natureza de uma operação de MPO (form. 4, 5 e 6):

$$
\begin{aligned}
& \text { ANDness }=(1 /(\mathrm{n}-1)) \Sigma((\mathrm{n}-\mathrm{i}) \mathrm{W} \text { ordem } \mathrm{i}) \\
& \text { ORness }=1-\text { ANDness } \\
& \text { Compensação }=1-\sqrt{\frac{n \sum\left(W_{\text {ordem }_{i}}-1 / n\right)^{2}}{n-1}}
\end{aligned}
$$

sendo:

n o número total de fatores; i a ordem dos fatores e $\mathrm{W}$ ordem i o peso para o fator da iésima ordem.

ANDness (ou ORness) é governado pela quantidade de desvio (skew) nos pesos de ordenação e a compensação é controlada pelo grau de dispersão nos pesos de ordenação. ANDness/ORness reflete uma atitude em relação ao risco na tomada de decisão. É representado por ANDness, o grau de aproximação do operador à operação MIN (AND); e por ORness o grau de aproximação do operador à operação MAX (OR). ANDness e ORness são complementares, sendo a soma dos dois igual a 1. Em um extremo, o ANDness absoluto (igual a 1) representa a posição de maior aversão a risco; e no outro extremo, ORness absoluto (igual a 1) representa a opção (atitude) mais arriscada. O segundo parâmetro, compensação, representa o grau segundo o qual diferentes fatores compensam-se uns com os outros.

O que é interessante na MPO é que é possível controlar, de forma contínua, os graus de ANDness/ORness e compensação (Figura 11). Por exemplo, usando-se pesos de ordenação de $\left[\begin{array}{lll}1 & 0 & 0\end{array}\right]$, o resultado é o operador de mínimo, com ANDness total e ausência de compensação (não disperso). Usando-se pesos de ordenação [ [ $\left.\begin{array}{lll}0 & 0 & 1\end{array}\right]$ resultado é o operador de máximo, com ORness total e ausência de compensação. 
Usando-se pesos de ordenação $[0,33$ 0,33 0,33] o resultado é o operador tradicional de médias de AMC com ANDness e ORness intermediários e compensação total entre fatores (totalmente disperso). Pesos de ordenação de [l $\left.\begin{array}{lll}0 & 1 & 0\end{array}\right]$ resultam em um operador com ANDness e ORness intermediários, mas sem compensação entre critérios, enquanto o exemplo original de pesos de ordenação $[0,50,3 \quad 0,2]$ proporciona um operador com substancial compensação e moderado grau de ANDness.

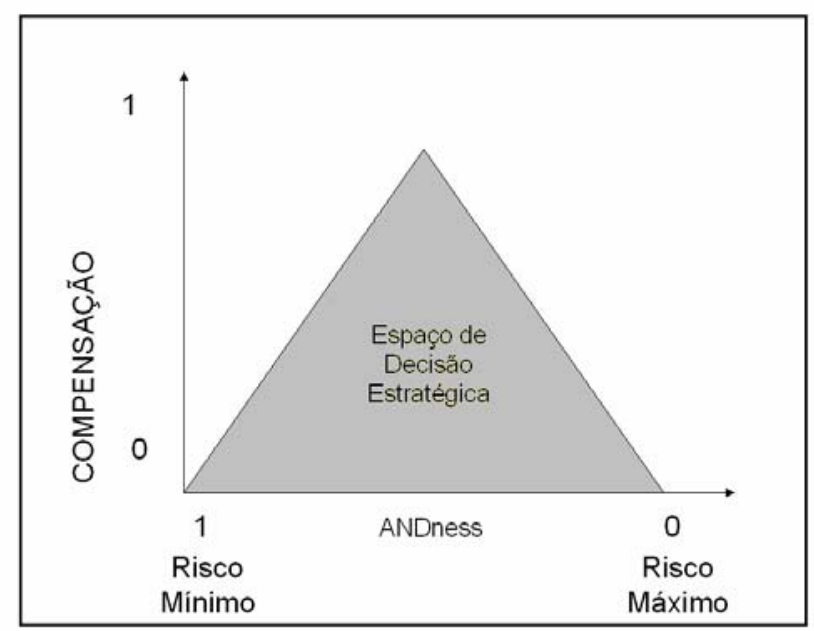

Figura 11 - Espaço de decisão estratégica no método da Média Ponderada Ordenada FONTE: Adaptado de Jiang e Eastman (2000)

O procedimento MPO foi incorporado ao Idrisi for Windows. Este procedimento pode ser aplicado em uma operação simples ou como parte de um projeto híbrido. Por exemplo, se houver cinco fatores, com três deles devendo compensar e dois não, o problema pode ser resolvido em dois estágios. No primeiro estágio, a MPO será aplicada usando-se pesos de ordenação com o grau desejado de compensação, seguido de uma segunda aplicação do procedimento, sem compensação, na qual o resultado da primeira aplicação é incluído como um fator adicional. Nas duas aplicações, pesos de critérios podem ser facilmente ajustados para manter os pesos originais de todos os fatores. 


\subsubsection{Passos metodológicos}

O fluxograma da Figura 12 apresenta as etapas desenvolvidas na condução deste trabalho, detalhadas a seguir.

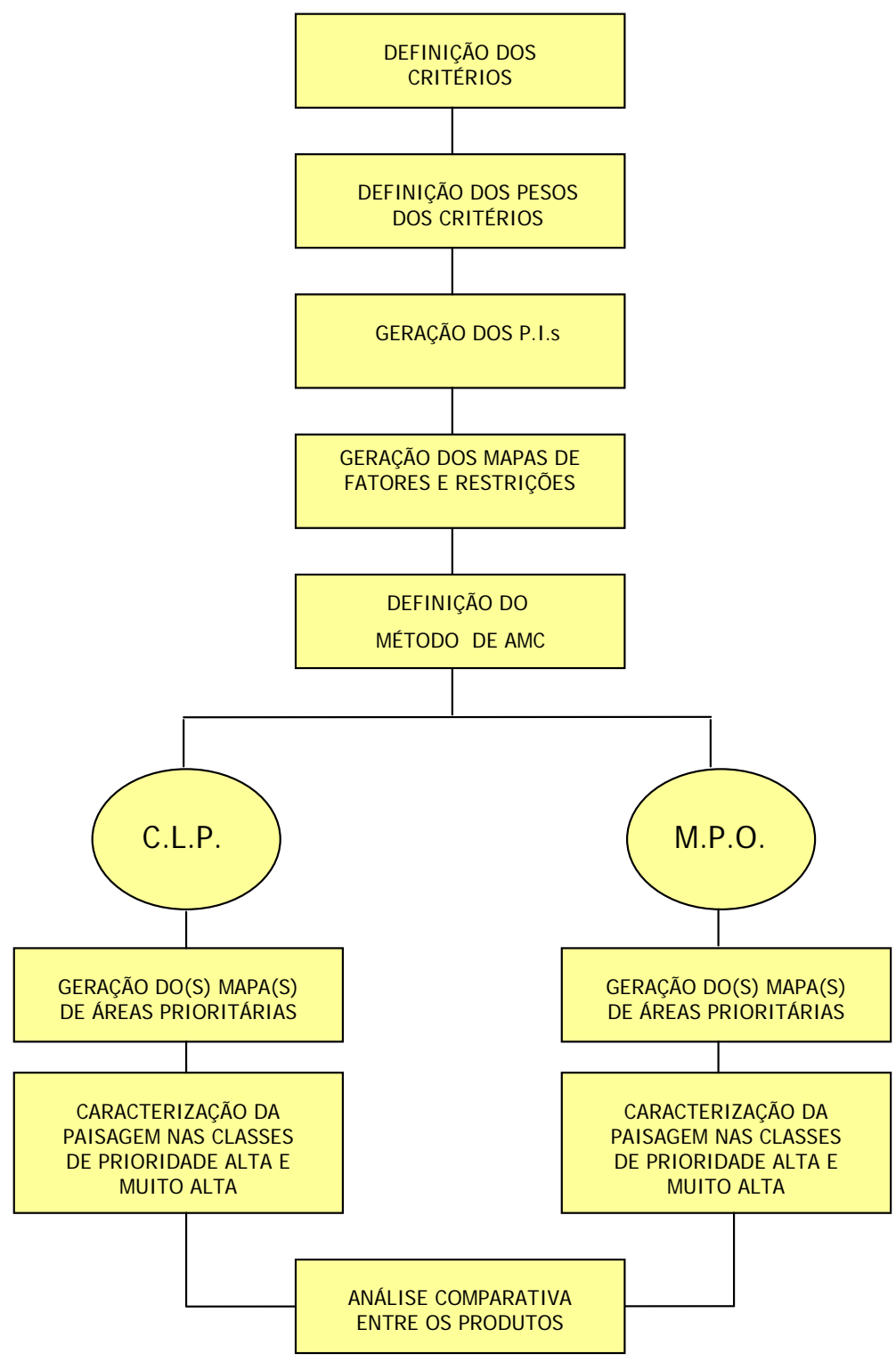

Figura 12 - Fluxograma das etapas desenvolvidas no presente trabalho 


\subsubsection{Definição dos critérios}

Tendo em vista o objetivo principal dessa Avaliação Multicritérios, isto é, definir áreas prioritárias à restauração florestal visando à conservação de recursos hídricos, foram definidos os critérios (fatores e restrições) a serem empregados na análise. Essa definição foi orientada por pesquisa bibliográfica e pela consulta a profissionais da área, por meio da Técnica Participatória (SAATY, 1977). Também foi importante na definição dos critérios, bem como de sua importância relativa (passo seguinte), a experiência do autor na coordenação de projeto análogo (IPEF, 2001).

\subsubsection{Definição dos pesos dos fatores}

$\mathrm{Na}$ avaliação da importância relativa dos fatores, ou seja, na definição dos pesos a serem utilizados na análise, foi empregada a Técnica Participatória, instrumentalizada pela Matriz de Comparação Pareada.

\subsubsection{Seleção dos planos de informação}

Os planos de informação necessários à geração dos mapas de fatores foram selecionados na base de dados cartográficos referentes à bacia do Rio Corumbataí, no Laboratório de Geoprocessamento do Departamento de Engenharia Rural, da ESALQ/USP.

\subsubsection{Geração dos mapas de fatores e de restrições}

A partir dos planos de informação selecionados foram gerados os mapas de fatores empregados na análise. Todos os mapas de fatores foram padronizados a uma escala comum de 0-255 (referente a imagens de 8 bits). Essa padronização é necessária devido ao fato de os fatores apresentarem diferentes unidades de medida (por exemplo quilômetros, graus etc.). A padronização faz com que os fatores sejam levados a uma unidade comum de medida (no caso deste trabalho é o grau de 
prioridade), bem como a uma escala comum a todos (0-255), tornando os fatores comensuráveis e possibilitando sua agregação pela AMC.

Também a partir dos planos de informação foi gerado o mapa de restrições, que é uma "máscara" booleana com a função de excluir determinadas áreas (por exemplo áreas urbanas, corpos d'água etc.) de consideração na AMC.

\subsubsection{Geração dos mapas de áreas prioritárias}

$\mathrm{Na}$ geração dos mapas de áreas prioritárias à restauração florestal foram empregados dois métodos de AMC: a tradicional Combinação Linear Ponderada (CLP) e a Média Ponderada Ordenada (MPO). Foi utilizado, para tanto, o módulo MCE (Multicriteria Evaluation) do Idrisi Kilimanjaro.

No método da MPO, dada a flexibilidade do mesmo na produção de cenários com diferentes níveis de risco e compensação, foram gerados três mapas de áreas prioritárias, correspondendo às seguintes situações: (a) risco médio/baixo, nível médio de compensação; (b) risco médio, compensação total entre fatores; (c) risco médio/alto, nível médio de compensação. Os cenários envolvendo risco mínimo e risco máximo, sem compensação entre fatores, não foram considerados, uma vez que correspondem aos resultados do Método Booleano, com os operadores AND e OR, respectivamente, considerados inadequados ao tipo de análise proposto neste trabalho.

A geração dos mapas de áreas prioritárias foi feita a partir do módulo Wizard, do Idrisi, para análises de decisão multicritérios. O Wizard é um conjunto seqüencial de diálogos, com o propósito de guiar o analista ao longo do processo de construção de modelos para resolver problemas de tomada de decisão multicritérios, tanto de um único como de múltiplos objetivos.

O processo inicia-se com a solicitação da criação de um arquivo, no qual todos os parâmetros do modelo são armazenados. A seguir deve-se fornecer o nome do objetivo (ou objetivos) e especificar os critérios a serem empregados na análise (fatores

e restrições), bem como os seus pesos, no caso obtidos por meio da matriz de comparação pareada. 
Com todos os elementos necessários à análise, o passo seguinte é a especificação do método a ser empregado na agregação dos fatores. Nesse ponto, duas são as opções: OWA (de Ordered Weighted Averaging, ou Média Ponderada Ordenada) e No OWA. A opção No OWA equivale ao método da CLP, uma vez que resulta no cenário de risco médio e compensação total entre fatores (vértice superior do espaço de decisão triangular - Figura 11). Se a opção for pelo método da MPO (OWA), é necessário incorporar ao procedimento os pesos de ordenação, cujo efeito é o posicionamento do cenário desejado no espaço triangular de decisões, em situações diversas de risco e de compensação entre fatores.

Antes da definição dos pesos de ordenação é preciso estabelecer a ordem do grau de influência para os fatores, na geração do mapa final de áreas prioritárias. Para isso faz-se um exercício, no qual se atribui todo o peso de ordenação, isto é, o valor um (1), a cada uma das cinco posições equivalentes aos cinco fatores. Assim, atribuindo-se o valor um à posição um e o valor zero às demais posições (dois a cinco), a semelhança do mapa final gerado com um dos fatores indicará qual o fator que deverá ocupar aquela posição e, assim, sucessivamente. A posição um (1) indica o fator com menor influência sobre o resultado final e a posição cinco (5), no outro extremo, indica o fator com maior influência sobre o resultado (mapa) final.

Estabelecida a ordem de grau de influência dos fatores, passa-se à atribuição dos pesos de ordenação a cada fator. No caso do cenário envolvendo risco médio e compensação total entre fatores, todos recebem o mesmo peso (igual a 0,2, no caso de cinco fatores). Para os demais cenários os pesos são atribuídos de maneira que os maiores valores (maior possibilidade de compensação) são atribuídos aos primeiros fatores (ordem obtida no ranqueamento feito no passo anterior), isto é, aos fatores com menor influência sobre o mapa final. Assim, os fatores com maior influência sobre o resultado final recebem os menores pesos de ordenação, significando baixa taxa de compensação.

Com a definição desse segundo conjunto de pesos, o sistema está pronto para gerar o mapa final de áreas prioritárias, de acordo com os parâmetros estabelecidos no decorrer do processo. 


\subsubsection{Reclassificação dos mapas de áreas prioritárias}

Para facilitar a comparação entre os mapas produzidos, as áreas prioritárias, geradas pelos dois métodos, foram reclassificadas em cinco categorias (classes de mesma amplitude), de acordo com o grau de prioridade para a restauração florestal, ou seja, prioridades: muito baixa, baixa, média, alta e muito alta.

\subsubsection{Caracterização ambiental das áreas prioritárias}

Para as áreas classificadas como de prioridades muito alta e alta, nos dois métodos, foi feita uma tabulação cruzada com mapas de características selecionadas da paisagem. Esse procedimento permitiu que fosse feita uma caracterização ambiental dessas áreas, auxiliando na análise comparativa entre os produtos.

\subsubsection{Análise comparativa entre os métodos}

De posse dos mapas gerados e dados quantitativos e qualitativos derivados dos mesmos, bem como dos resultados da verificação de campo, foi realizada uma análise comparativa entre os métodos. 


\section{RESULTADOS E DISCUSSÃO}

\subsection{Definição dos critérios}

\subsubsection{Fatores}

Como resultado da aplicação da Técnica Participatória, bem como da consulta à bibliografia e da experiência prévia em projetos análogos, foram definidos os seguintes fatores, tendo em vista o objetivo da AMC: adequação do uso da terra; erodibilidade do solo; erosividade da chuva; proximidade à malha viária; e proximidade à rede hidrográfica.

\subsubsection{Adequação do uso da terra}

Em se tratando da preocupação com a produção de sedimentos, por meio da erosão, e suas conseqüências sobre os recursos hídricos, a adequação do uso da terra assume destaque. O uso inadequado da terra, ou seja, sua utilização além da capacidade de uso sem degradação significativa, é responsável por grande parte da erosão acelerada em áreas rurais.

A adaptação das terras às várias modalidades de utilização agrossilvopastoril diz respeito, segundo Lepsch (1983), "a sua capacidade de uso, idéia esta diretamente ligada às possibilidades e limitações que elas apresentam. Pode-se conceituar capacidade de uso da terra como a sua adaptabilidade para fins diversos, sem que sofra depauperamento pelos fatores de desgaste e empobrecimento. A expressão encerra efeitos de condições do meio físico (incluindo o clima) na aptidão da terra para ser utilizada sem sofrer danos consideráveis por desgaste e empobrecimento, através de cultivos anuais, perenes, pastagem, reflorestamento ou vida silvestre".

O autor segue comentando que "o sistema de capacidade de uso é uma classificação técnica, originalmente desenvolvida nos Estados Unidos, representando um grupamento qualitativo de tipos de solo sem considerar a localização ou as

características econômicas da terra: diversas características e propriedades são 
sintetizadas, visando à obtenção de classes homogêneas de terras, em termos do propósito de definir sua máxima capacidade de uso sem risco de degradação do solo, especialmente no que diz respeito à erosão acelerada".

O emprego do sistema de classificação de terras segundo sua capacidade de uso permite aos planejadores atuarem sobre a questão do aproveitamento do potencial produtivo das terras e, ao mesmo tempo, sobre a conservação dos recursos naturais.

Muito embora a adequação do uso da terra, especificamente, não tenha sido empregada como um fator em avaliações multicritérios revisadas neste trabalho, o uso da terra em si, ou uso e cobertura do solo, é um fator quase sempre presente em análises ambientais, como em Richardson e Gatti (1999), Perry et al. (1999), Vettorazzi, Valente e Ballester (2000), IPEF (2001), Robinson et al. (2002), Baban e Wan-Yusof (2003) e Dragan et al. (2003).

\subsubsection{Erodibilidade do solo}

Erodibilidade diz respeito à propriedade do solo relacionada a sua suscetibilidade natural à erosão. Assim, é coerente a inclusão da erodibilidade entre os fatores de importância a serem considerados em uma análise de múltiplos critérios, com o objetivo de identificar áreas prioritárias à restauração florestal, visando à conservação de recursos hídricos.

Bertoni e Lombardi Neto (1985) comentam que o significado de erodibilidade do solo é diferente de erosão do solo. A intensidade de erosão em uma área qualquer pode ser influenciada mais pelo declive, características das chuvas, cobertura vegetal e manejo, do que pelas propriedades do solo. Contudo, alguns solos são mais facilmente erodidos que outros, mesmo quando o declive, a precipitação, a cobertura vegetal e as práticas de controle de erosão são as mesmas. Essa diferença, devida às propriedades inerentes ao solo, é referida como erodibilidade do solo.

A erodibilidade tem sido utilizada diretamente como um fator, em análises espaciais envolvendo vários critérios, como em Adinarayana et al. (1999), Richardson e Gatti (1999) e IPEF (2001), ou indiretamente, compondo fatores como vulnerabilidade à erosão, exemplificado em Valente e Vettorazzi (2005). 


\subsubsection{Erosividade da chuva}

Partindo-se do princípio de que a capacidade da chuva em provocar erosão é variável ao longo da área de estudo, decidiu-se pela inclusão da erosividade entre os fatores a serem utilizados na Avaliação Multicritérios, com base principalmente em IPEF (2001). Optou-se pelo emprego da erosividade média para o mês de novembro, pelo seu valor alto e, também, por considerar que o impacto de chuvas intensas sobre o solo é mais significativo em novembro do que em janeiro (outro valor alto e possível de ser usado), já que a cobertura vegetal seria menor e menos eficiente na proteção contra chuvas intensas no início da estação chuvosa.

A erosividade da chuva, segundo Bertoni e Lombardi Neto (1985), é um índice numérico que expressa a capacidade da chuva, esperada em dada localidade, de causar erosão em uma área sem proteção. Os autores comentam que estudos de dados de perdas de solo, associados com as características de chuva, mostraram que, quando os outros fatores, à exceção da chuva, são mantidos constantes, as perdas de solo ocasionadas pelas chuvas nos terrenos cultivados são diretamente proporcionais ao valor do produto de duas características da chuva: sua energia cinética total e sua intensidade máxima em trinta minutos. Esse produto representa um termo de interação que mede o efeito de como a erosão por impacto, o salpico e a turbulência se combinam com a enxurrada para transportar as partículas de solo desprendidas. $\mathrm{O}$ produto da energia cinética pela intensidade, ou valor El - índice de erosão - é considerado a melhor relação encontrada para medir o potencial erosivo da chuva.

Dentre os trabalhos revisados, Adinarayana et al. (1999) e Richardson e Gatti (1999) também empregaram a erosividade como critério a ser considerado na produção de sedimentos, uma vez que trabalharam com a Equação Universal de Perda de Solo.

\subsubsection{Proximidade à malha viária}

A relação entre malha viária e erosão do solo é amplamente conhecida e aceita, com influência significativa sobre a qualidade e a quantidade de água superficial em determinada região. 
Em avaliações multicritérios envolvendo diferentes objetivos, porém tendo em comum o interesse pela avaliação da produção de sedimentos, a proximidade a estradas foi incluída como um fator relevante em IPEF (2001), Dragan et al. (2003) e Valente e Vettorazzi (2005).

A construção e o uso de estradas e caminhos de acesso resultam em impactos e mudanças ao longo de seu percurso e, quando inadequadamente locadas e construídas ou mantidas, as estradas são uma das principais causas antrópicas de erosão e produção de sedimentos, com forte impacto sobre os recursos naturais, resultando em perdas econômicas relacionadas ao assoreamento dos cursos d'água, inundações, degradação de zonas ripárias e dos próprios corpos d'água, degradação da qualidade da água etc. (FAO, 1989).

A erosão que resulta de estradas e caminhos é originada por causas físicas naturais, como geologia, tipo de solo e quantidade e intensidade de precipitação. A densidade da malha viária, quantificada pelo comprimento total de vias por unidade de área, está diretamente relacionada à erosão. A locação de caminhos e estradas em relação ao declive, aos canais naturais de drenagem e a solos sensíveis, tem um efeito direto sobre a quantidade de sedimentos que irá atingir a rede de drenagem. A severidade do impacto erosivo está relacionada ao total de superfície exposta pelas vias, à densidade de drenagem, ao relevo (declividade, comprimento e forma das encostas), a fatores geológicos (tipos de rocha, posição no perfil e drenagem subsuperficial) e ao clima. Quanto maiores a intensidade e a freqüência de chuvas e quanto mais densa a rede de drenagem, maior é a necessidade de se planejarem medidas de redução do impacto da erosão, decorrente de estradas e caminhos, sobre a produção de sedimentos e a qualidade da água (FAO, 1989; CARVER, 1988).

\subsubsection{Proximidade à rede hidrográfica}

Por fim, entre os fatores importantes à conservação dos recursos hídricos por meio de restauração florestal, foi incluída a proximidade à rede hidrográfica. A idéia por trás do uso desse fator é a de que a cobertura florestal é importante à geração de água de qualidade em uma bacia hidrográfica, independentemente da sua distância aos 
elementos da rede de drenagem, porém essa importância, em geral, cresce à medida que a distância para o corpo d'água, ou nascente, diminui.

Nas encostas, a cobertura florestal auxilia diretamente na prevenção à erosão, favorece a infiltração da água, alimentando o lençol freático, entre outras funções. Já às margens dos corpos d'água a vegetação florestal, à semelhança de faixas de proteção, é uma das medidas de proteção para os mananciais. Embora não seja uma medida de eficiência total, a manutenção de uma cobertura florestal adequada margeando os elementos da drenagem é uma providência significativa na conservação dos recursos hídricos, apresentando uma série de características positivas, como: promove uma proteção direta aos corpos d'água, dificultando a entrada de poluentes via escoamento superficial e subsuperficial; representa uma proteção direta contra a erosão das margens de cursos d'água, lagos e represas; colabora na manutenção de temperaturas favoráveis à biota aquática por meio de sombreamento; trata-se de importante reduto da biodiversidade (flora e fauna) local etc.

Como comentado por Lima (2005), a integridade do sistema ripário é um dos fatores fundamentais para a resiliência de microbacias, ou seja, sua capacidade de sofrer alterações sem perder significativamente sua funcionalidade hidrológica.

A proximidade à rede hidrográfica foi um dos fatores adotados em avaliações multicritérios conduzidas por Dragan et al (2003), Ferraz e Vettorazzi (2003) e Valente e Vettorazzi (2005).

A despeito de haver legislação específica sobre a questão da preservação da faixa de vegetação margeando corpos d'água, neste trabalho não se considerou, na análise, a recomendação quanto à largura de faixas, como consta do Código Florestal. Optou-se pela abordagem que conduziria à geração de áreas prioritárias à restauração florestal levando em consideração apenas aspectos da paisagem, naturais ou antrópicos.

\subsubsection{Restrições}

Foram consideradas como restrições, para o propósito deste trabalho, as áreas de floresta nativa, de cerrado, o Horto de Rio Claro, as áreas de mineração, a rede 
hidrográfica, a malha viária e as áreas urbanas, ou seja, todas as áreas onde não foi considerada a possibilidade de restauração da cobertura florestal.

\subsection{Definição dos pesos dos fatores}

A importância relativa entre fatores foi definida durante o próprio processo de definição dos fatores, por meio da matriz de comparação pareada.

O método da matriz de comparação pareada, proposto por Saaty (1977) para a atribuição de pesos aos fatores em avaliações multicritérios, tem sido utilizado com sucesso em diversos trabalhos, como por exemplo em Frutuoso; Vettorazzi e Couto (1999), Vettorazzi, Valente e Ballester (2000), Basnet; Apan e Raine (2001), IPEF (2001) e Valente e Vettorazzi (2005).

A relação de importância entre cada par de fatores foi quantificada empregandose a escala contínua de nove pontos, o que possibilitou o cálculo do peso de cada fator (Tabela 3).

A Taxa de Consistência (TC) obtida para a matriz foi de 0,06 , valor este menor que 0,10 , o que, conforme, Saaty (1980), indica que os valores de comparação entre os fatores foram gerados aleatoriamente, não havendo a necessidade de reorganização da matriz, por meio da alteração dos valores de comparação entre fatores.

O fator de maior peso foi a proximidade à rede hidrográfica $(0,4024)$, seguido de erodibilidade $(0,2425)$, adequação do uso do solo $(0,1570)$, proximidade à malha viária $(0,1541)$ e, finalmente, erosividade $(0,0440)$. Essa ponderação tem influência direta sobre a espacialização das áreas prioritárias à restauração a serem geradas pela análise, esperando-se, nesse caso, uma certa concentração das mesmas próximo aos elementos da drenagem, uma vez que o fator proximidade à rede hidrográfica foi o que recebeu o maior peso, e em áreas de solos mais sensíveis à erosão (maior erodibilidade). 
Tabela 3 - Matriz de comparação pareada entre os fatores definidos para a Avaliação Multicritérios

\begin{tabular}{lcccccc}
\hline & Adequa. & Erodib. & Erosiv. & Malha & Rede & Pesos \\
\hline Adequa. & 1 & & & & & 0,1570 \\
Erodib. & 1 & 1 & & & & 0,2425 \\
Erosiv. & $1 / 5$ & $1 / 5$ & 1 & & & 0,0440 \\
Malha & 2 & $1 / 3$ & 3 & 1 & & 0,1541 \\
Rede & 3 & 2 & 7 & 3 & 1 & 0,4024 \\
\hline Taxa de Consistência $(\mathrm{TC})=0,06$ & & & & 1,0000
\end{tabular}

Adequa. = adequação do uso do solo; Erodib. = erodibilidade do solo; Erosiv. = erosividade da chuva; Malha $=$ proximidade à malha viária; e Rede = proximidade à rede hidrográfica

\subsection{Seleção dos planos de informação}

Com a definição dos critérios (fatores e restrições) a serem empregados na análise, o passo seguinte foi a seleção dos planos de informação necessários à geração das imagens de fatores e de restrições. Esses planos foram selecionados no banco de dados do Laboratório de Geoprocessamento do Departamento de Engenharia Rural da ESALQ/USP, sendo os seguintes: uso e cobertura do solo; classes de capacidade de uso da terra; erodibilidade do solo; erosividade da chuva; malha viária e rede hidrográfica. A descrição desses planos de informação encontra-se no item 3.1.2 Base de dados cartográficos, do capítulo MATERIAL E MÉTODOS.

\subsection{Geração das imagens de fatores e de restrições}

\subsubsection{Imagens de fatores}




\subsubsection{Adequação do uso da terra}

A imagem do fator adequação do uso da terra foi gerada a partir do cruzamento entre os planos de informação classes de capacidade de uso da terra e uso e cobertura do solo, resultando na imagem de adequação com duas categorias apenas: uso adequado e uso não adequado.

Uma imagem booleana para uso não adequado foi então gerada e cruzada com classes de capacidade de uso, produzindo uma imagem com oito categorias, correspondentes às oito classes de capacidade de uso. A essa imagem foram agregadas as áreas com uso adequado. Aplicando-se uma função linear crescente, essa última imagem foi padronizada para 256 bytes, sendo o menor valor (28) atribuído às áreas de uso adequado e o maior valor (255) às áreas da classe VIII e uso não adequado (Figura 13a).

\subsubsection{Erodibilidade do solo}

A imagem do fator erodibilidade do solo foi produzida a partir da aplicação de uma função linear crescente sobre a imagem do plano de informação erodibilidade do solo. Assim, a imagem desse fator foi padronizada para 256 bytes (Figura 13b)

\subsubsection{Erosividade da chuva}

A partir do plano de informação erosividade da chuva, gerou-se a imagem do fator correspondente (Figura 13c), da mesma forma que no caso da erodibilidade, ou seja, simplesmente padronizando os valores para uma escala de 256 bytes, por meio de uma função linear crescente. 


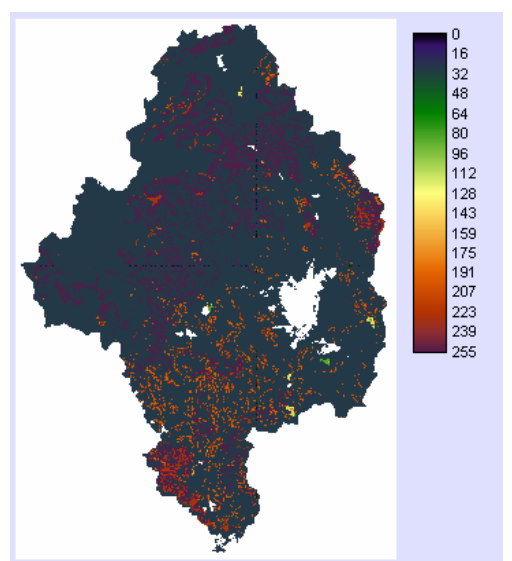

(a)

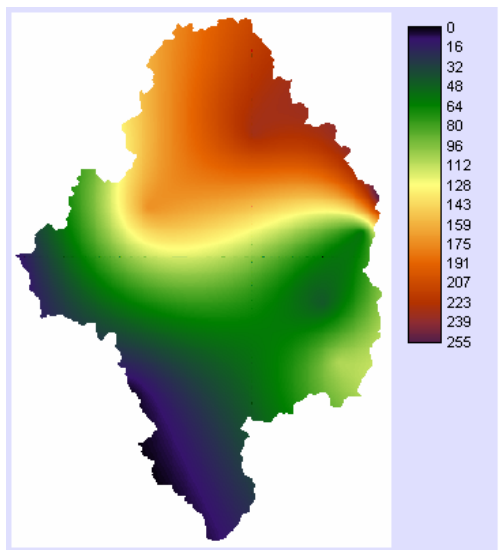

(c)

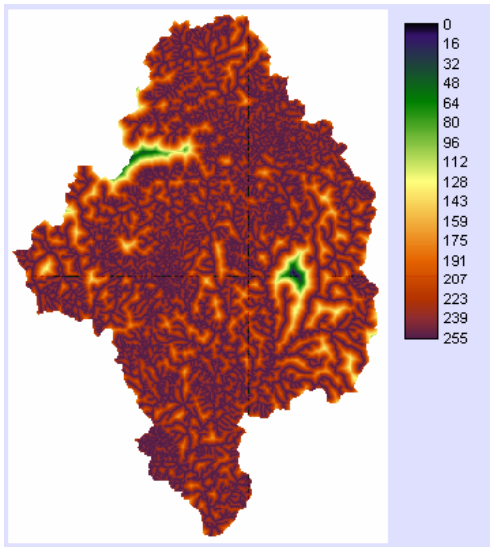

(e)

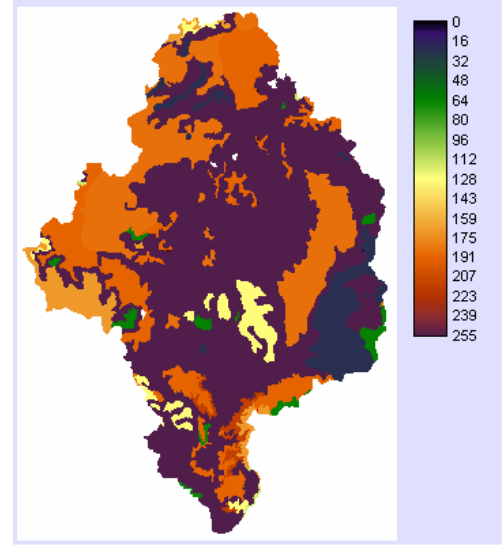

(b)

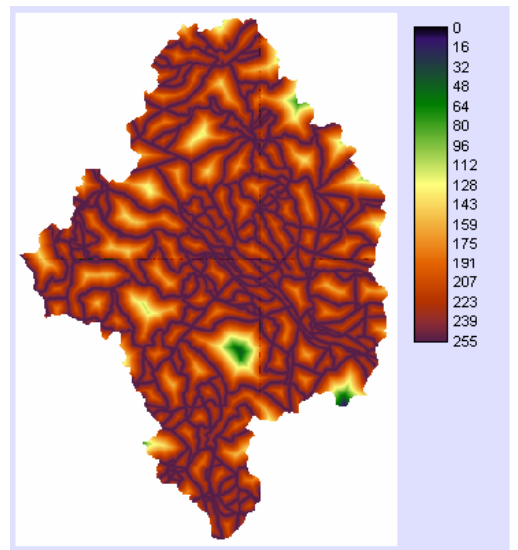

(d)

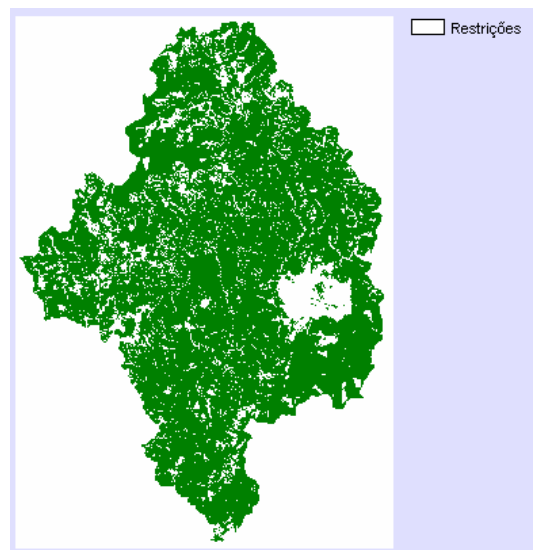

(f)

Figura 13 - Fatores e restrições da Avaliação Multicritérios: (a) adequação do uso da terra; (b) erodibilidade do solo; (c) erosividade da chuva; (d) proximidade à malha viária; (e) proximidade à rede hidrográfica; (f) restrições. 


\subsubsection{Proximidade à malha viária}

A partir do plano de informação malha viária foi gerada a imagem de distâncias que, posteriormente, foi padronizada para a escala de 256 bytes, nesse caso por uma função linear decrescente, de maneira que, quanto mais próximos às estradas, maiores eram os valores na imagem (Figura 13d).

\subsubsection{Proximidade à rede hidrográfica}

A imagem do fator proximidade à rede hidrográfica foi produzida de forma análoga à do fator proximidade à malha viária. Assim, na imagem desse fator, quanto mais próximos aos elementos da rede, maiores os valores dos pixels na imagem (Figura 13e).

\subsubsection{Imagem de restrições}

Na produção da imagem de restrições, gerou-se uma imagem booleana onde o valor 0 (zero) foi atribuído aos pixels correspondentes às áreas onde não foi considerada a possibilidade de restauração florestal (florestas nativas, cerrados, Horto de Rio Claro, áreas de mineração, malha viária, rede hidrográfica e áreas urbanas) e o valor 1 (um) às áreas onde seria possível a restauração (Figura 13f).

\subsection{Geração dos mapas de áreas prioritárias}

Seguindo-se a seqüência definida no módulo Wizard, do Idrisi, para tomadas de decisão multicritérios, foram gerados os mapas finais de áreas prioritárias à restauração florestal, pelos métodos da Combinação Linear Ponderada (Figura 14) e da Média Ponderada Ordenada, nesse caso para os cenários de nível médio de compensação entre fatores, com riscos médio/baixo (Figura 15) e médio/alto (Figura 16). 


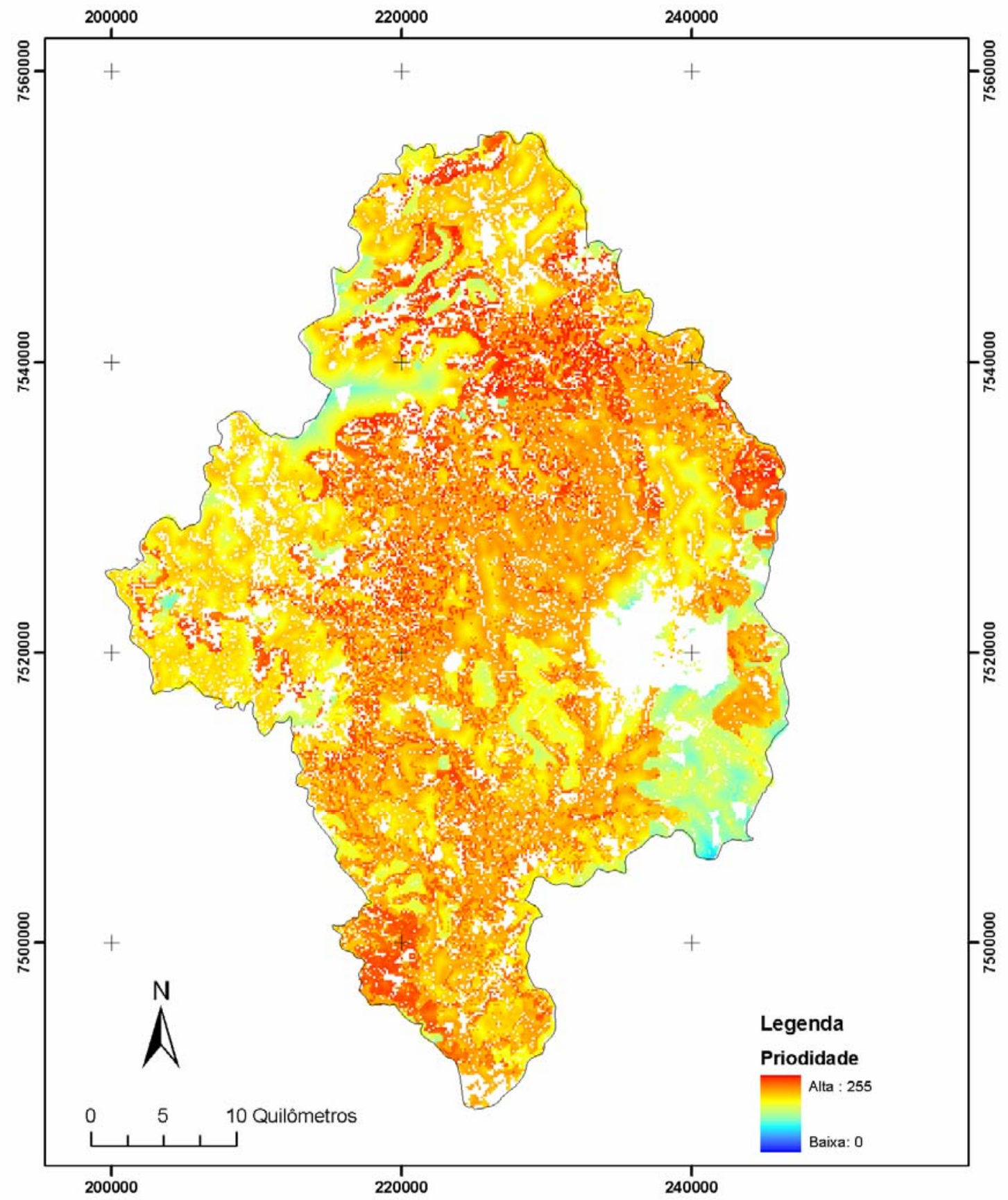

Figura 14 - Áreas prioritárias à restauração florestal geradas pelo método da Combinação Linear Ponderada (escala contínua de prioridades) 


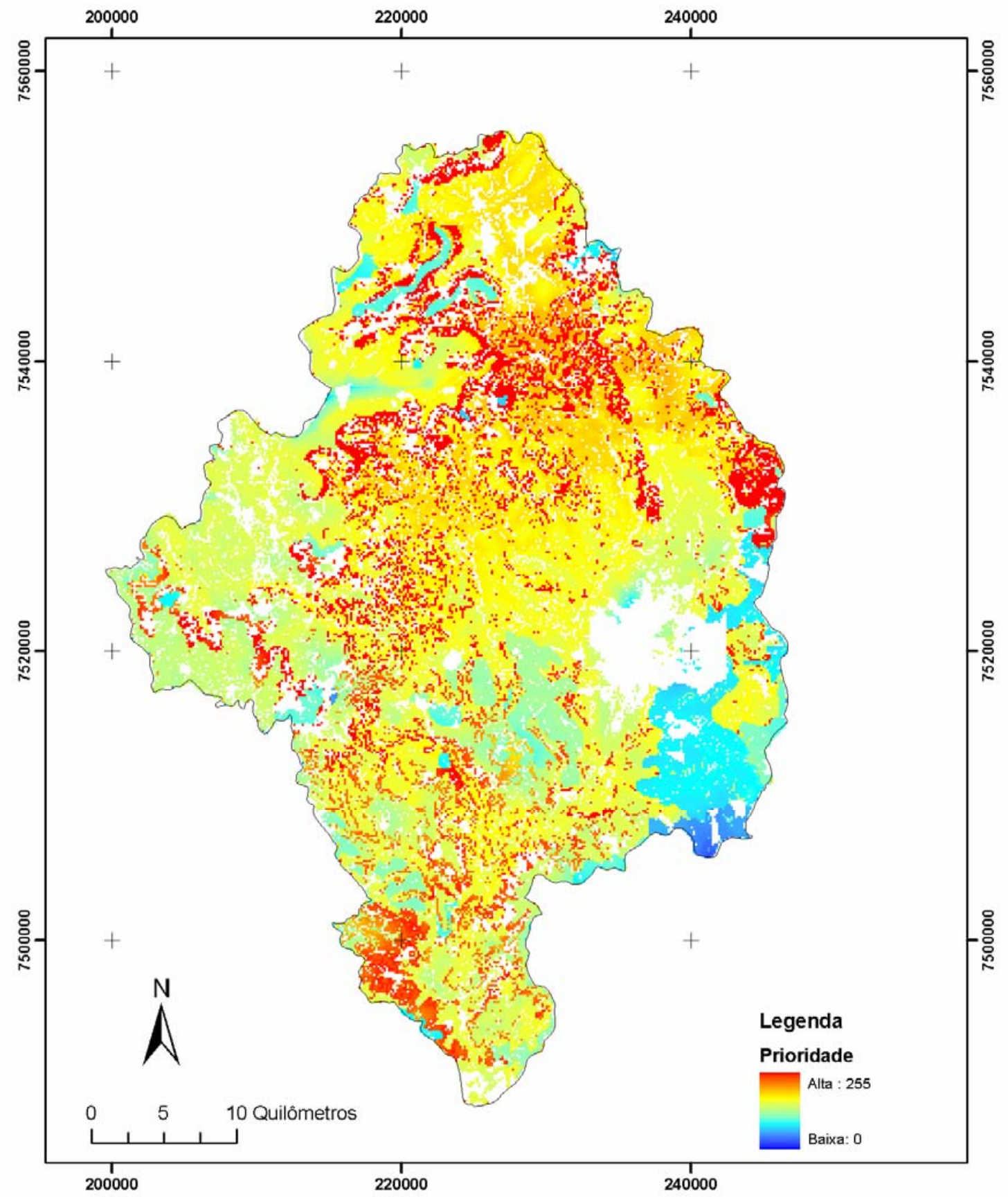

Figura 15 - Áreas prioritárias à restauração florestal geradas pelo método da Média Ponderada Ordenada, risco médio/baixo (escala contínua de prioridades) 


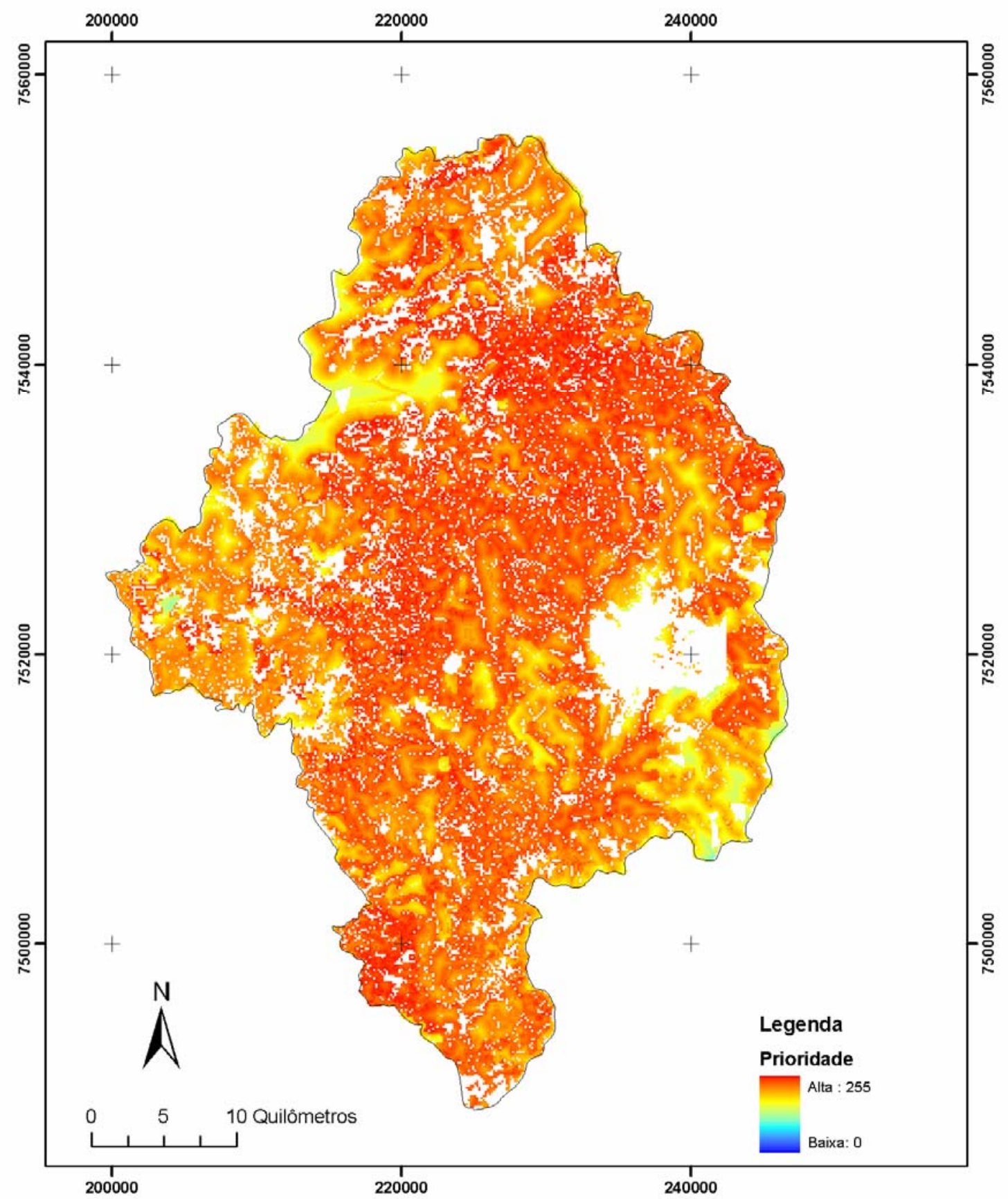

Figura 16 - Áreas prioritárias à restauração florestal geradas pelo método da Média Ponderada Ordenada, risco médio/alto (escala contínua de prioridades) 
Para o caso do método da MPO, antes da geração do mapa final para cada cenário desejado, foi necessária a atribuição de um segundo conjunto de pesos, os chamados pesos de ordenação, que são apresentados na Tabela 4.

Tabela 4 - Pesos de ordenação para os fatores utilizados na Avaliação Multicritérios, pelo Método da Média Ponderada Ordenada

\begin{tabular}{|c|c|c|c|c|c|c|c|}
\hline \multirow[b]{2}{*}{ Cenário } & \multicolumn{5}{|c|}{$\begin{array}{c}\text { Fatores (em ordem inversa de grau de influência } \\
\text { sobre o resultado final) }\end{array}$} & \multirow[b]{2}{*}{ Risco } & \multirow{2}{*}{$\begin{array}{l}\text { Compen- } \\
\text { sação }\end{array}$} \\
\hline & $\begin{array}{l}\text { Adequa. } \\
\text { (1) }\end{array}$ & $\begin{array}{l}\text { Erosiv. } \\
\text { (2) }\end{array}$ & $\begin{array}{l}\text { Erodib. } \\
\text { (3) }\end{array}$ & $\begin{array}{l}\text { Malha } \\
\text { (4) }\end{array}$ & $\begin{array}{l}\text { Rede } \\
\text { (5) }\end{array}$ & & \\
\hline $\begin{array}{l}\text { Risco médio/baixo, } \\
\text { compensação média }\end{array}$ & 0,4300 & 0,2639 & 0,1900 & 0,0941 & 0,0220 & 0,7464 & 0,6465 \\
\hline $\begin{array}{l}\text { Risco médio, } \\
\text { compensação total } \\
\text { (equivalente à CLP) }\end{array}$ & 0,2000 & 0,2000 & 0,2000 & 0,2000 & 0,200 & 0,5000 & 1,0000 \\
\hline $\begin{array}{l}\text { Risco médio/alto, } \\
\text { compensação média }\end{array}$ & 0,0220 & 0,0941 & 0,1900 & 0,2639 & 0,4300 & 0,2536 & 0,6465 \\
\hline
\end{tabular}

Adequa. = adequação do uso do solo; Erosiv. = erosividade da chuva; Erodib. = erodibilidade do solo; Malha = proximidade à malha viária; e Rede $=$ proximidade à rede hidrográfica

Os mapas finais foram, a seguir, reclassificados em cinco níveis de prioridade (Figuras 17 a 19), para facilitar a análise comparativa entre os mesmos, além de tornar mais fácil a sua leitura. 


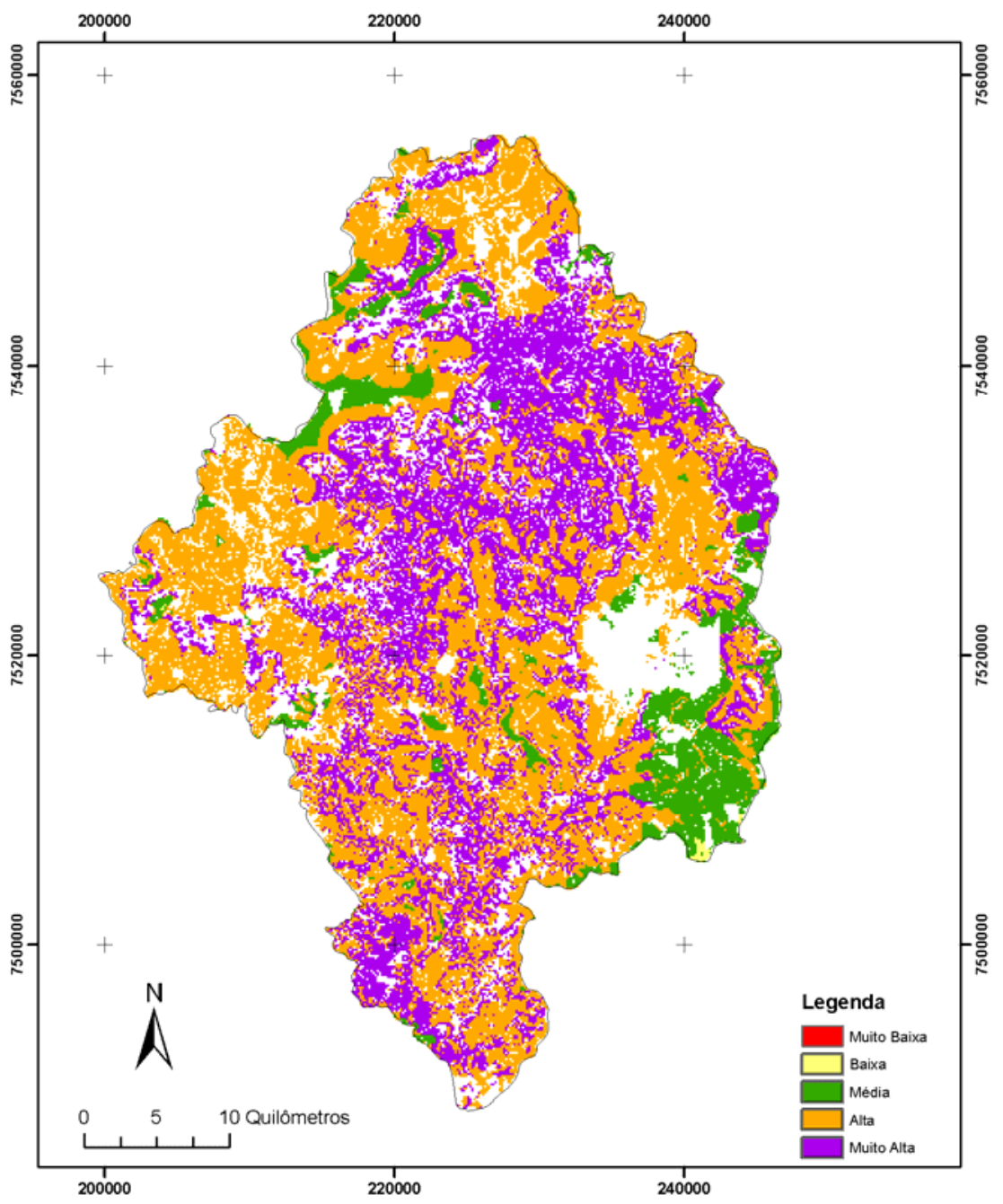

Figura 17 - Áreas prioritárias à restauração florestal geradas pelo método da Combinação Linear Ponderada (cinco níveis de prioridade)

Tabela 5 - Valores de área para os cinco níveis de prioridade obtidos pela aplicação do método da Combinação Linear Ponderada

\begin{tabular}{ccc}
\hline \multirow{2}{*}{ Nível de prioridade } & \multicolumn{2}{c}{ Área } \\
\cline { 2 - 3 } & $($ ha) & $(\%)$ \\
\hline Muito baixo & 0,20 & 0,00 \\
Baixo & 174,68 & 0,13 \\
Médio & $12.774,92$ & 9,40 \\
Alto & $73.241,20$ & 53,88 \\
Muito Alto & $49.741,08$ & 36,59 \\
\hline Total & $135.932,08$ & 100,00 \\
\hline
\end{tabular}




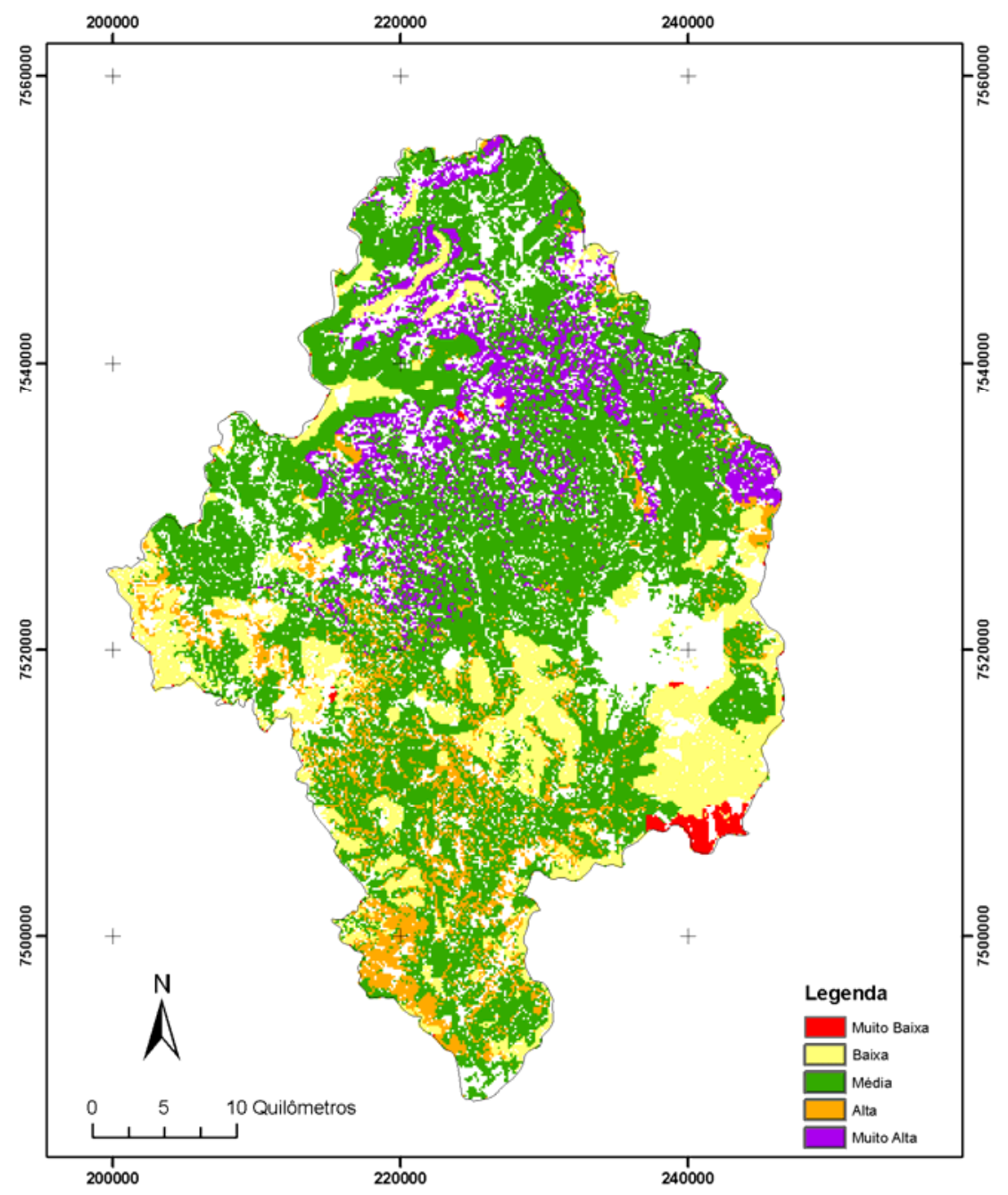

Figura 18 - Áreas prioritárias à restauração florestal geradas pelo método da Média Ponderada Ordenada, risco médio/baixo (cinco níveis de prioridade)

Tabela 6 - Valores de área para os cinco níveis de prioridade obtidos pela aplicação do método da Média Ponderada Ordenada, risco médio/baixo

\begin{tabular}{ccc}
\hline \multirow{2}{*}{ Nível de prioridade } & \multicolumn{2}{c}{ Área } \\
\cline { 2 - 3 } & $($ ha) & $(\%)$ \\
\hline Muito baixo & $1.128,44$ & 0,84 \\
Baixo & $23.578,24$ & 17,34 \\
Médio & $85.651,72$ & 63,01 \\
Alto & $13.108,56$ & 9,64 \\
Muito Alto & $12.465,12$ & 9,17 \\
\hline Total & $135.932,08$ & 100,00 \\
\hline
\end{tabular}




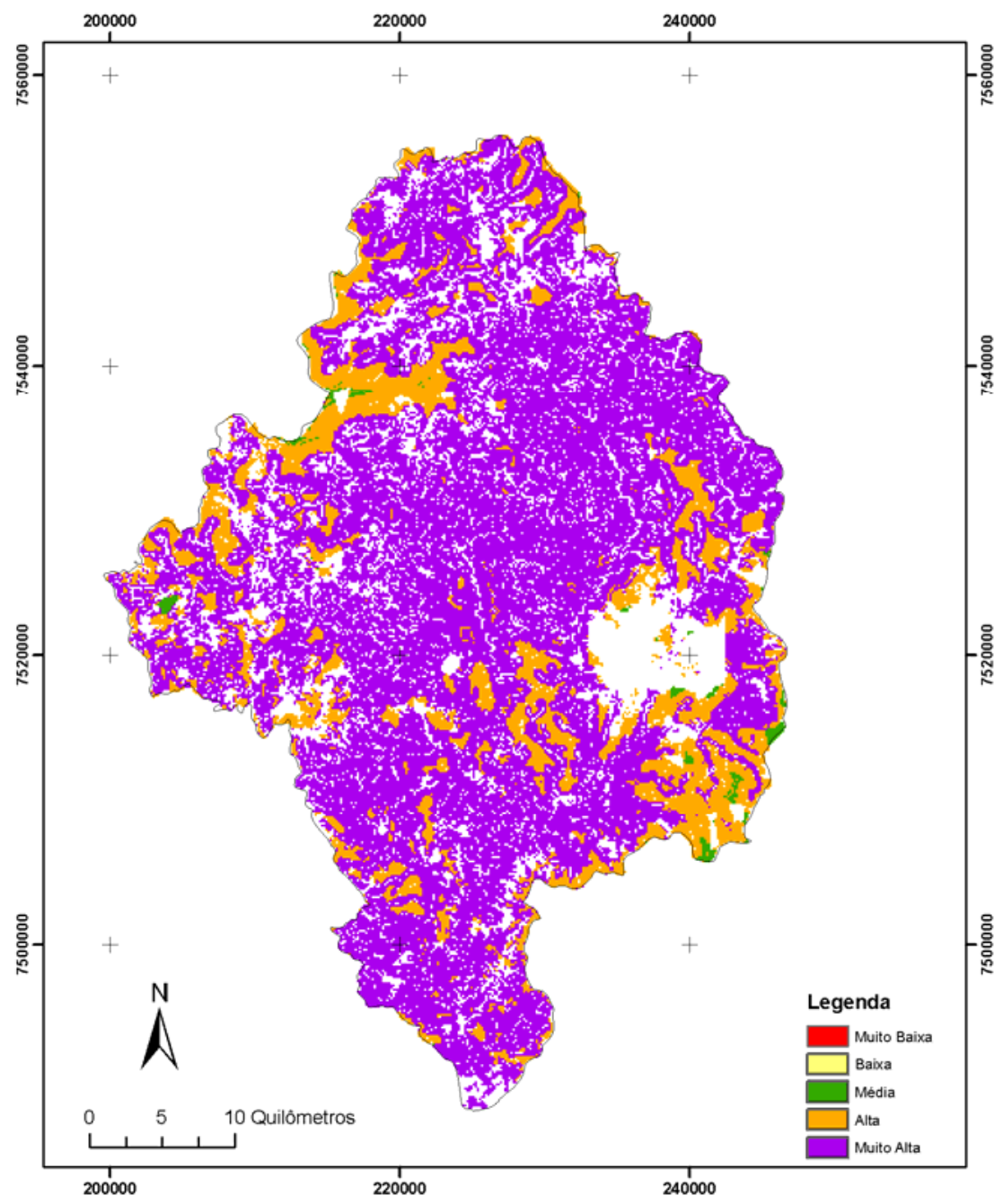

Figura 19 - Áreas prioritárias à restauração florestal geradas pelo método da Média Ponderada Ordenada, risco médio/alto (cinco níveis de prioridade)

Tabela 7 - Valores de área para os cinco níveis de prioridade obtidos pela aplicação do método da Média Ponderada Ordenada, risco médio/alto

\begin{tabular}{ccc}
\hline \multirow{2}{*}{ Nível de prioridade } & \multicolumn{2}{c}{ Área } \\
\cline { 2 - 3 } & $($ ha) & $(\%)$ \\
\hline Muito baixo & 0,00 & 0,00 \\
Baixo & 0,68 & 0,00 \\
Médio & 887,80 & 0,65 \\
Alto & $26.898,52$ & 19,79 \\
Muito Alto & $108.145,08$ & 79,56 \\
\hline Total & $135.932,08$ & 100,00 \\
\hline
\end{tabular}


A análise visual dos mapas com os cinco níveis categóricos de prioridade já possibilita uma primeira inferência sobre sua adequação. Enquanto o mapa referente ao método da MPO, com risco médio/baixo e compensação média entre fatores (Figura 18), apresenta uma distribuição mais coerente das áreas com os diferentes graus de prioridade, isto é, valores crescentes das áreas de prioridade muito baixa até as de prioridade média, decrescendo a seguir até o grau de prioridade muito alto (Tabela 6), concentrando a maior porcentagem no grau médio, o mesmo comportamento não é observado nos outros dois mapas. No mapa gerado pelo método da CLP (Figura 17) os valores de área são crescentes até o nível alto, diminuindo no muito alto, porém com uma concentração elevada nos dois últimos níveis (90,47\%), como pode ser observado na Tabela 5. No mapa referente ao método da MPO, com risco médio/alto e compensação média (Figura 19), a distribuição das categorias é ainda mais atípica, com valores crescentes de área, do nível baixo de prioridade (não ocorreu, nesse cenário, o nível de prioridade muito baixo) até o muito alto, com forte concentração neste último, conforme dados da Tabela 7. Deve-se deixar claro que o valor da área total da bacia que consta das Tabelas 5 a 7 refere-se à área total passível de restauração, isto é, aplicadas as devidas restrições apresentadas na Figura 25.

No mapa gerado pela CLP, especificamente para as áreas classificadas como de prioridades alta e muito alta, pode-se perceber nitidamente a influência dos fatores erodibilidade e proximidade à rede hidrográfica na espacialização dessas áreas, porque são os fatores com os maiores pesos na análise (Tabela 3). No método da MPO, a conformação geral dos mapas finais é uma decorrência também dos pesos de ordenação e do ranqueamento dos fatores, isto é, a ordem dos fatores relacionada a sua influência no mapa final (Tabela 4).

Com relação ao método da MPO, o cenário referente a risco médio/baixo e taxa de compensação média entre fatores proporcionou aquele que foi avaliado como o resultado mais coerente, uma vez que a atribuição dos pesos de ordenação foi bastante apropriada, ou seja, os maiores pesos foram atribuídos aos fatores com menor influência sobre a espacialização das classes no mapa final (Tabela 4), favorecendo a compensação entre fatores. 
No cenário relativo a risco médio/alto, como os pesos de ordenação mais altos (Tabela 4) foram atribuídos aos fatores que já tinham uma grande influência sobre o mapa final (e, em alguns casos, também um alto peso de compensação), isso gerou uma área muito grande coberta pelas classes de prioridade alta e muito alta.

Para a caracterização ambiental das áreas classificadas como de graus alto e muito alto de prioridade, foi feito o cruzamento entre os mapas finais de prioridade e alguns planos de informação selecionados, para os três casos (cenários) estudados (Tabelas 8 a 10).

Tabela 8 - Caracterização ambiental das áreas com graus de prioridade alto e muito alto, obtidas pelo método da Combinação Linear Ponderada

\begin{tabular}{|c|c|c|c|c|c|}
\hline $\begin{array}{c}\text { Grau de } \\
\text { prioridade }\end{array}$ & $\begin{array}{c}\text { Uso e } \\
\text { cobertura do } \\
\text { solo }\end{array}$ & Solo & $\begin{array}{l}\text { Erodibilidade } \\
\text { do solo }\end{array}$ & $\begin{array}{c}\text { Declividade } \\
\text { do terreno (\%) }\end{array}$ & $\begin{array}{c}\text { Distância à } \\
\text { rede } \\
\text { hidrográfica } \\
\text { (m) }\end{array}$ \\
\hline \multirow{3}{*}{ Alto } & & & & & $\begin{array}{c}0-500 \\
(83,37 \%)\end{array}$ \\
\hline & $\begin{array}{c}\text { Pastagem } \\
(51,37 \%)\end{array}$ & $\begin{array}{c}\mathrm{PV} \\
(38,01 \%)\end{array}$ & $\begin{array}{c}\text { Alta } \\
(52,90 \%)\end{array}$ & $\begin{array}{c}0-2 \\
(45,85 \%)\end{array}$ & $\begin{array}{l}100-200 \\
(26,05 \%)\end{array}$ \\
\hline & $\begin{array}{c}\text { Cana } \\
(33,96 \%)\end{array}$ & $\begin{array}{c}\text { LV } \\
(35,30 \%)\end{array}$ & $\begin{array}{l}\text { Muito alta } \\
(38,84 \%)\end{array}$ & $\begin{array}{c}5-10 \\
(25,55 \%)\end{array}$ & $\begin{array}{l}200-300 \\
(25,13 \%)\end{array}$ \\
\hline \multirow{3}{*}{ Muito alto } & Pastagem & PV & \multirow{3}{*}{$\begin{array}{l}\text { Muito alta } \\
(96,92 \%)\end{array}$} & $\begin{array}{c}15-45 \\
(32,68 \%)\end{array}$ & $\begin{array}{c}0-500 \\
(97,81 \%)\end{array}$ \\
\hline & & & & $0-2$ & $\begin{array}{c}0-100 \\
(41,31 \%)\end{array}$ \\
\hline & $\begin{array}{c}\text { Cana } \\
(28,48 \%)\end{array}$ & $\begin{array}{c}\mathrm{Li} \\
(29,30 \%)\end{array}$ & & $\begin{array}{c}(29,56 \%) \\
10-15 \\
(20,36 \%)\end{array}$ & $\begin{array}{l}100-200 \\
(36,64 \%)\end{array}$ \\
\hline
\end{tabular}


Tabela 9 - Caracterização ambiental das áreas com graus de prioridade alto e muito alto, obtidas pelo método da Média Ponderada Ordenada, risco médio/baixo

\begin{tabular}{|c|c|c|c|c|c|}
\hline $\begin{array}{c}\text { Grau de } \\
\text { prioridade }\end{array}$ & $\begin{array}{c}\text { Uso e } \\
\text { cobertura do } \\
\text { solo }\end{array}$ & Solo & $\begin{array}{l}\text { Erodibilidade } \\
\text { do solo }\end{array}$ & $\begin{array}{c}\text { Declividade } \\
\text { do terreno (\%) }\end{array}$ & $\begin{array}{l}\text { Distância à } \\
\text { rede } \\
\text { hidrográfica } \\
\text { (m) }\end{array}$ \\
\hline \multirow{3}{*}{ Alto } & & & & & $\begin{array}{c}0-500 \\
(93,21 \%)\end{array}$ \\
\hline & $\begin{array}{c}\text { Cana } \\
(63,19 \%)\end{array}$ & $\begin{array}{c}\text { PV } \\
(46,08 \%)\end{array}$ & $\begin{array}{l}\text { Muito alta } \\
(89,35 \%)\end{array}$ & $\begin{array}{c}15-45 \\
(46,22 \%)\end{array}$ & $\begin{array}{l}100-200 \\
(35,48 \%)\end{array}$ \\
\hline & $\begin{array}{c}\text { Pastagem } \\
(31,23 \%)\end{array}$ & $\begin{array}{c}\mathrm{Li} \\
(44,06 \%)\end{array}$ & $\begin{array}{c}\text { Alta } \\
(10,61 \%)\end{array}$ & $\begin{array}{c}10-15 \\
(32,97 \%)\end{array}$ & $\begin{array}{c}0-100 \\
(27,56 \%)\end{array}$ \\
\hline \multirow{3}{*}{ Muito alto } & & & & & $\begin{array}{c}0-500 \\
(96,59 \%)\end{array}$ \\
\hline & $\begin{array}{c}\text { Pastagem } \\
(76,63 \%)\end{array}$ & $\begin{array}{c}\mathrm{Li} \\
(52,74 \%)\end{array}$ & $\begin{array}{l}\text { Muito alta } \\
(98,05 \%)\end{array}$ & $\begin{array}{c}15-45 \\
(71,12 \%)\end{array}$ & $\begin{array}{c}100-200 \\
(3803 \%)\end{array}$ \\
\hline & $\begin{array}{c}\text { Cana } \\
(12,97 \%)\end{array}$ & $\begin{array}{c}\text { PV } \\
(45,44 \%)\end{array}$ & $\begin{array}{c}\text { Alta } \\
(1,95 \%)\end{array}$ & $\begin{array}{c}10-15 \\
(14,84 \%)\end{array}$ & $\begin{array}{c}0-100 \\
(31,24 \%)\end{array}$ \\
\hline
\end{tabular}

Tabela 10 - Caracterização ambiental das áreas com graus de prioridade alto e muito alto, obtidas pelo método da Média Ponderada Ordenada, risco médio/alto

\begin{tabular}{|c|c|c|c|c|c|}
\hline $\begin{array}{l}\text { Grau de } \\
\text { prioridade }\end{array}$ & $\begin{array}{l}\text { Uso e } \\
\text { cobertura do } \\
\text { solo }\end{array}$ & Solo & $\begin{array}{l}\text { Erodibilidade } \\
\text { do solo }\end{array}$ & $\begin{array}{c}\text { Declividade } \\
\text { do terreno (\%) }\end{array}$ & $\begin{array}{l}\text { Distância à } \\
\text { rede } \\
\text { hidrográfica } \\
\text { (m) }\end{array}$ \\
\hline Alto & $\begin{array}{c}\text { Cana } \\
(52,73 \%) \\
\text { Pastagem } \\
(27,90 \%)\end{array}$ & $\begin{array}{c}\text { LV } \\
(47,20 \%) \\
\text { LR } \\
(23,15 \%)\end{array}$ & $\begin{array}{c}\text { Alta } \\
(51,90 \%) \\
\\
\text { Baixa } \\
(23,21 \%) \\
\text { Média } \\
(20,82 \%)\end{array}$ & $\begin{array}{c}0-2 \\
(55,01 \%) \\
5-10 \\
(22,61 \%)\end{array}$ & $\begin{array}{c}500-1000 \\
(46,31 \%) \\
\\
0-500 \\
(44,44 \%) \\
\\
200-800 \\
(84,33 \%)\end{array}$ \\
\hline Muito alto & $\begin{array}{c}\text { Pastagem } \\
(59,76 \%) \\
\text { Cana } \\
(30,31 \%)\end{array}$ & $\begin{array}{c}\text { PV } \\
(55,82 \%) \\
\text { LV } \\
(14,88 \%) \\
\text { Li } \\
(14,69 \%)\end{array}$ & $\begin{array}{c}\text { Muito alta } \\
(70,00 \%) \\
\text { Alta } \\
(26,29 \%)\end{array}$ & $\begin{array}{c}0-2 \\
(36,77 \%) \\
15-45 \\
(20,43 \%) \\
5-10 \\
(20,34 \%)\end{array}$ & $\begin{array}{c}0-500 \\
(96,28 \%) \\
\\
100-200 \\
(35,52 \%) \\
0-100 \\
(29,22 \%)\end{array}$ \\
\hline
\end{tabular}


Nos três cenários gerados, verifica-se que nas áreas classificadas como de grau de prioridade muito alto para restauração florestal, o uso da terra predominante é a pastagem, vindo em seguida a cana-de-açúcar. A predominância da pastagem é mais significativa no mapa obtido pela MPO, com risco médio/baixo, onde a pastagem responde por $76,63 \%$ da área e a cana-de-açúcar por $12,97 \%$.

Quanto aos solos, verifica-se uma predominância de PV e de Li nas áreas de prioridade muito alta para os três métodos. Na CLP o PV predomina, com $67,76 \%$ contra 29,30\% para o Li. Na MPO, risco médio/baixo, a predominância inverte-se, passando para o Li, com 52,74\%, contra $45,44 \%$ para o PV. Na MPO, risco médio/alto, novamente a predominância recai sobre o PV, com 55,82\%. Nesse cenário, dada a grande porcentagem de áreas classificadas como de prioridade muito alta, o LV aparece em segundo lugar na relação dos solos dominantes, embora praticamente com o mesmo percentual do Li (14,88\% e 14,69\%, respectivamente).

Essa predominância de solos sensíveis à erosão, no caso Li e PV, é traduzida pelos valores altos de erodibilidade, fazendo com que a predominância quanto a esse índice recaia sobre a faixa mais problemática, ou seja, erodibilidade muito alta, para os três métodos empregados. O menor percentual foi observado no método da MPO risco médio/alto (70,00\%), como resultado da inclusão de Latossolos na classe de prioridade muito alta, enquanto que os outros dois métodos apresentaram porcentagens bastante elevadas dessa faixa (96,92\% para a CLP e 98,05\% para a MPO, risco médio/baixo).

Com relação à declividade do terreno houve um destaque para a classe que vai de $15 \%$ a $45 \%$. Ela representa $32,68 \%$ das áreas de prioridade muito alta no mapa gerado pelo método da CLP e $71,12 \%$ no mapa produzido pela MPO, risco médio/baixo. Apenas para o método da MPO, risco médio/alto, ela não foi a classe de declividade predominante, vindo em segundo lugar, com 20,43\%, atrás da classe 0-2\%, com $36,77 \%$. Esse resultado é explicado pela extensa área coberta pela faixa com grau de prioridade muito alto, nesse cenário, incluindo áreas de LV. Novamente observa-se uma coerência maior na distribuição das classes de declividade para o cenário envolvendo a MPO, risco médio/baixo. Nele há a predominância da classe 15-45\% (71,12\%), seguida da classe 10-15\% (14,84\%), perfazendo mais de $4 / 5$ da área passível de restauração florestal na bacia. 
Outra característica interessante a ser descrita, para as áreas de prioridade muito alta, é a sua proximidade à rede hidrográfica. Em todos os casos elas se concentraram nos primeiros $200 \mathrm{~m}$ a partir dos cursos d'água, com $77,95 \%$ para a CLP, $69,27 \%$ para a MPO com risco médio/baixo e $64,74 \%$ para a MPO com risco médio/alto. Neste aspecto houve uma diferenciação entre os dois métodos, uma vez que na CLP a maior concentração se deu nos primeiros $100 \mathrm{~m}$ (41,31\%) e na MPO ela ocorreu na faixa entre $100 \mathrm{~m}$ e $200 \mathrm{~m}$, com 38,03\% para o cenário de risco médio/baixo e 35,52\% para o de risco médio/alto .

De uma forma resumida, pode-se dizer, então, que as áreas mapeadas como de prioridade muito alta, para todos os cenários, são caracterizadas por apresentar a pastagem como uso da terra predominante, sobre solos de erodibilidade muita alta, prevalecendo PV e Li, com declividades entre 15\% e 45\% (à exceção do método da MPO, risco médio/alto, onde a classe de declividade predominante foi a de 0-2\%) e concentrando-se nos primeiros $200 \mathrm{~m}$ a partir dos elementos da drenagem.

Já as áreas classificadas como de prioridade alta podem ser caracterizadas, resumidamente, como apresentando a cana-de-açúcar como uso predominante da terra, sobre solos de erodibilidade alta, com predomínio de PV, em áreas de relevo praticamente plano (declividade na classe 0-2\%) e ocupando preferencialmente a faixa de $100 \mathrm{~m}$ a $200 \mathrm{~m}$ a partir dos cursos d'água. As exceções ficam por conta da pastagem, como uso predominante no método da CLP; do LV, como solo predominante para o mapa da MPO, risco médio/alto; erodibilidade muito alta, para a MPO risco médio/baixo, onde também a classe de declividade difere dos outros dois cenários (1545\%); e, por fim, a distância à rede hidrográfica, que na MPO, risco médio/alto, diferenciou-se significativamente dos outros dois cenários, com $84,33 \%$ das áreas concentrando-se na ampla faixa que vai de $200 \mathrm{~m}$ a $800 \mathrm{~m}$.

Partindo da constatação de que a maior coerência nos resultados parece estar no método da MPO, risco médio/baixo, pode-se estabelecer, então, para esse cenário, uma caracterização geral das áreas classificadas como de graus de prioridade alto e muito alto (Tabela 11). 
Tabela 11 - Caracterização geral das áreas classificadas como de prioridades alta e muito alta, para restauração florestal, geradas pelo método da Média Ponderada Ordenada, risco médio/baixo.

\begin{tabular}{cccccc}
\hline $\begin{array}{c}\text { Grau de } \\
\text { prioridade }\end{array}$ & $\begin{array}{c}\text { Uso e } \\
\text { cobertura do } \\
\text { solo }\end{array}$ & Solo & $\begin{array}{c}\text { Erodibilidade } \\
\text { do solo }\end{array}$ & $\begin{array}{c}\text { Declividade } \\
\text { do terreno } \\
(\%)\end{array}$ & $\begin{array}{c}\text { Distância à rede } \\
\text { hidrográfica }(\mathrm{m})\end{array}$ \\
\hline Alto & Cana & PV/Li & Muito alta & $15-45$ & $100-200$ \\
Muito alto & Pastagem & Li/PV & Muito alta & $15-45$ & $100-200$ \\
\hline
\end{tabular}

\subsection{Análise comparativa entre os métodos}

Dada a importância que as áreas de prioridade muito alta apresentam para o processo de tomada de decisão quanto à restauração florestal, sua distribuição espacial para os três cenários é, a seguir, apresentada (Figuras 20 a 22) e discutida.

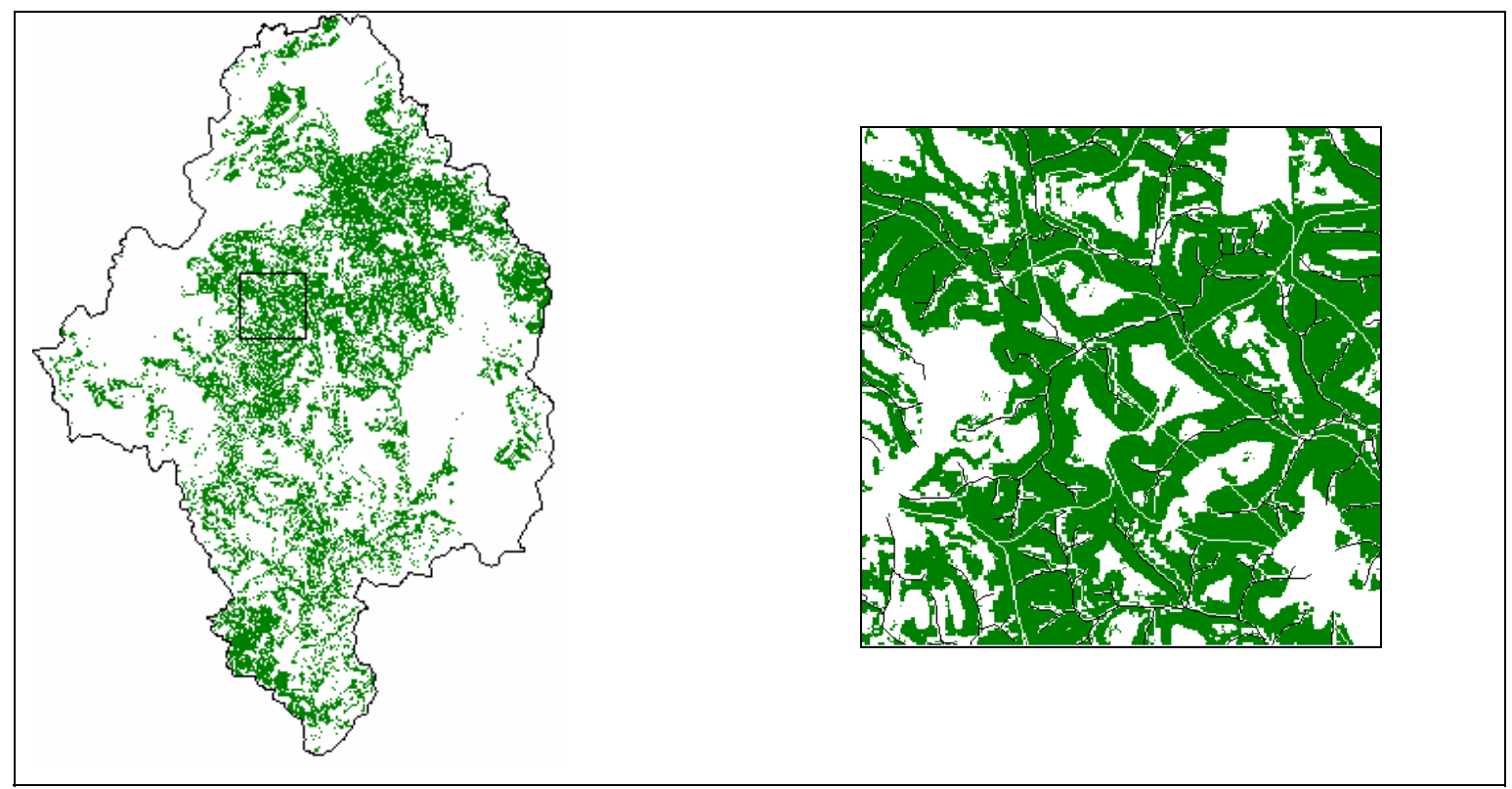

Figura 20 - Distribuição espacial das áreas de prioridade muito alta para restauração florestal, na bacia do Rio Corumbataí, geradas pelo método da Combinação Linear Ponderada, com detalhe ampliado 


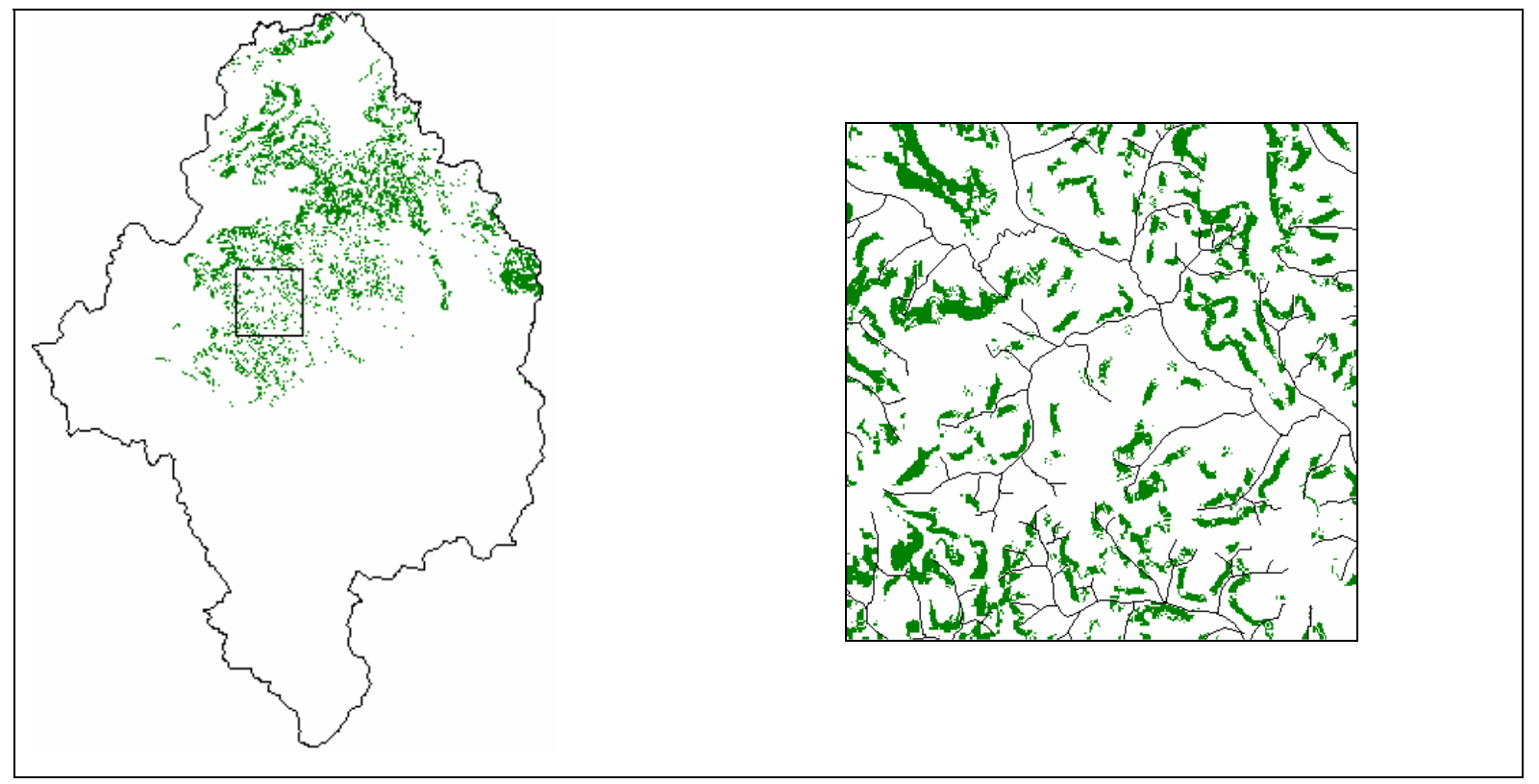

Figura 21 - Distribuição espacial das áreas de prioridade muito alta para restauração florestal, na bacia do Rio Corumbataí, geradas pelo método da Média Ponderada Ordenada, risco médio/baixo, com detalhe ampliado

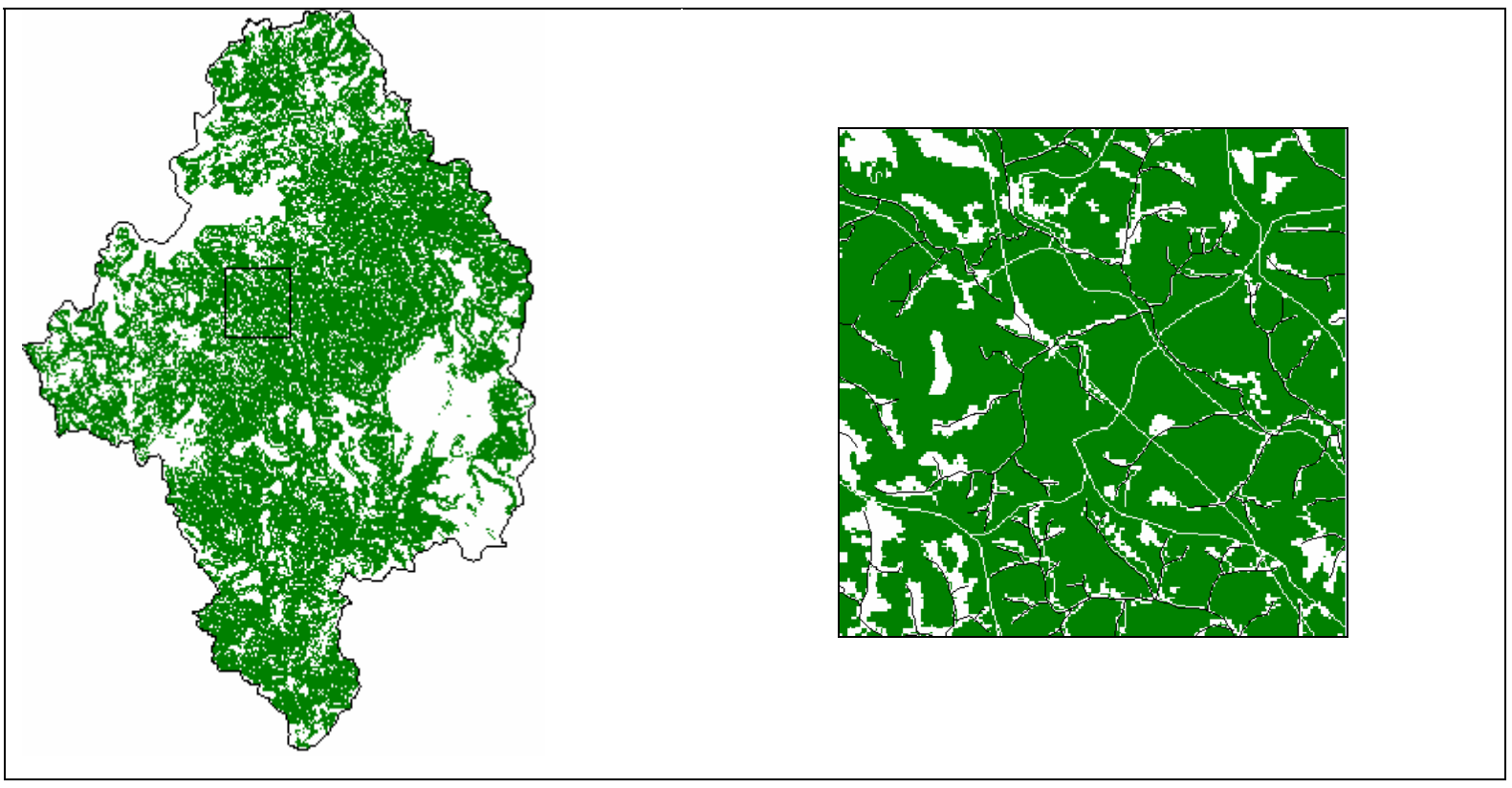

Figura 22 - Distribuição espacial das áreas de prioridade muito alta para restauração florestal, na bacia do Rio Corumbataí, geradas pelo método da Média Ponderada Ordenada, risco médio/alto, com detalhe ampliado 
A observação das Figuras 20, 21 e 22 aponta uma diferença acentuada na distribuição espacial das áreas de prioridade muito alta na bacia do Rio Corumbataí e, como era de se esperar, a área coberta por essa classe diminui, à medida que o risco considerado na análise também diminui. Assim, na Figura 22, referente ao resultado do método da MPO, risco médio/alto, observa-se que a maior parte da bacia foi classificada como de prioridade muito alta (79,56\%, de acordo com a Tabela 7 ), o que não é uma situação esperada em uma análise de prioridades. Essa cobertura alta diminui no método da CLP (Figura 20), onde o risco assume o valor médio e a compensação entre fatores é total; mas, ainda uma área significativa da bacia é classificada como de prioridade muito alta (36,59\%, conforme dados apresentados na Tabela 5). Apenas no cenário referente ao método da MPO, risco médio/baixo e compensação média entre fatores, é que a distribuição das áreas consideradas de prioridade muito alta é mais coerente com o resultado esperado de uma análise de prioridades, cobrindo apenas $9,17 \%$ da bacia (Tabela 6 ), com uma concentração na porção central das regiões do Médio e do Alto Corumbataí, o que pôde ser constatado em verificações no campo e durante sobrevôos realizados na área de estudo, quando chamou a atenção a situação de áreas nessas regiões, principalmente de pastagens, degradadas, com cursos d'água de ordens mais baixas seriamente comprometidos pelo processo de assoreamento (Figura 23).

No entanto, é a observação dos detalhes ampliados, que acompanham as Figuras 20 a 22, que pode fornecer mais elementos para a análise comparativa dos resultados obtidos pelos três cenários. A área coberta pelos detalhes é a mesma, ou seja, com limites idênticos, nos três casos. Foi selecionado em uma região onde era possível encontrar áreas de prioridade muito alta para os três cenários. 


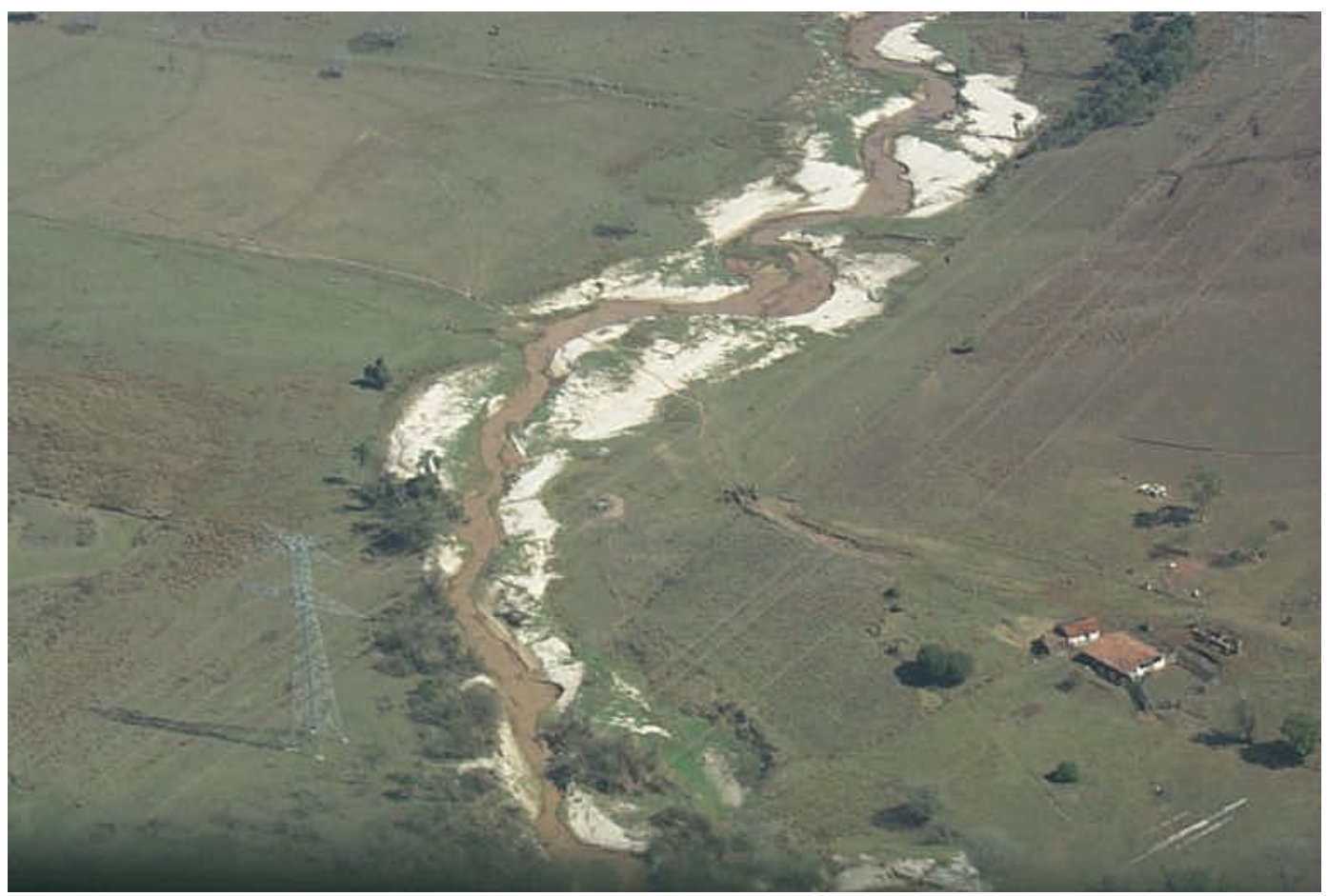

Figura 23 - Assoreamento em curso d'água, em área de pastagens na região do Alto Corumbataí

(Arquivo do Projeto Corumbataí, IPEF (2001))

Como pode ser visto na Figura 22, no caso do método da MPO, risco médio/alto, houve uma generalização na distribuição espacial das áreas de prioridade muito alta, com uma cobertura extensa, claramente não compatível com uma análise de prioridades, contudo explicável pelo fato de estar próximo do cenário referente ao operador booleano MAX ou OR, de união (risco máximo, sem compensação entre fatores).

A Combinação Linear Ponderada gerou um resultado (Figura 20) em que as áreas de prioridade muito alta apresentaram uma distribuição espacial mais restrita, com uma concentração aparente ao redor dos corpos d'água, delineando como que uma área tampão (buffer) para a rede hidrográfica, porém ainda resultando em um valor alto (de área) para o caso da classe de grau mais elevado de prioridade para restauração. 
O método da CLP gerou um resultado interessante, porém sem o detalhamento desejável em uma análise de prioridades, o que foi obtido, como discutido adiante, pelo método da MPO. A CLP conduz a uma priorização regional, e não local, como já observado em outros trabalhos, a exemplo de Araújo (1999), IPEF (2001) e Valente (2005).

Dos três cenários avaliados, o que apresentou a maior coerência e compatibilidade com uma análise de prioridades foi o relativo ao método da MPO, com risco médio/baixo e compensação média entre fatores (Figura 21), uma situação intermediária entre a CLP e o operador booleano MIN ou AND, de intersecção. As áreas individualizadas foram menores em superfície e maiores em número que nos dois cenários anteriores. Resultados semelhantes foram obtidos por Araújo (1999), tendo o autor constatado que "a análise por MPO definiu os melhores resultados, com os mapas obtidos mostrando um maior número de classes em pequenas áreas. Em comparação, a análise por CLP apresentou resultados coerentes, mas sem detalhar as áreas menores". É interessante mencionar que, como colocado por Chen e Blong (2003), as tomadas de decisão, nesse caso definição de áreas prioritárias à restauração florestal, envolvem preferências espaciais e/ou padrões.

As áreas classificadas como de prioridade muito alta, na MPO risco médio/baixo, distribuíram-se em áreas restritas da paisagem, ora próximas à rede hidrográfica, com uma tendência à proximidade às cabeceiras dos elementos de drenagem, ora nos interflúvios, de acordo com as características fisiográficas determinadas pelos fatores selecionados para a AMC. A distribuição espacial dessas áreas, próximas às cabeceiras e aos cursos d'água de ordens inferiores, vai ao encontro do que preconizam Burkart; James e Tomer (2004). Para esses autores, as áreas ripárias ao longo dos canais de primeira ordem têm um potencial maior de interceptação da água, subterrânea ou superficial, que áreas similares ao longo de canais de ordens superiores, contribuindo dessa forma para a descarga desses cursos pequenos, que é dominada pelo fluxo de base. Lima (2005) também comenta a importância da proteção adequada das zonas ripárias e das cabeceiras de drenagem, para garantir a integridade do sistema ripário, contribuindo, dessa forma, para aumentar a resiliência da bacia hidrográfica, diminuindo a sua vulnerabilidade a perturbações. 
Por outro lado, não é possível pensar-se em proteção adequada à bacia apenas com uma cobertura florestal ao redor das nascentes e ao longo dos elementos da drenagem. As áreas de encosta, quando utilizadas de forma inadequada, são as principais fontes de sedimentos carreados aos cursos d'água e necessitam de atenção especial quanto ao seu manejo, com práticas de conservação do solo. Há locais em que os fatores da paisagem, naturais e antrópicos, convergem para uma situação crítica, caracterizando essas áreas como "sensíveis" ou "vulneráveis", podendo, dependendo do grau de vulnerabilidade, ser utilizadas como áreas de proteção por meio de restauração florestal. Machado, Vettorazzi e Xavier (2003) reforçam essa idéia, comentando a necessidade de tratar a paisagem em bacias hidrográficas de forma global, identificando "áreas sensíveis ambientalmente", onde são necessárias práticas de controle dos processos erosivos e não somente ações de proteção dispensadas apenas às zonas ripárias, por meio da preservação ou restauração da mata ciliar. $\mathrm{Na}$ mesma linha, Richardson e Gatti (1999) estimaram a produção potencial de sedimentos carreados aos cursos d'água, por meio da aplicação da Equação Universal de Perda de Solo em ambiente SIG, delineando e priorizando áreas em uma microbacia para fim de restauração florestal, visando à proteção dos recursos hídricos.

A despeito do método da CLP ser um dos mais amplamente utilizados em AMC, por sua fácil implementação em SIGs, empregando operações de álgebra de mapas e modelagem cartográfica, e fácil entendimento pelos tomadores de decisão (MALCZEWSKI, 2000, 2004), a MPO pode substituí-lo, com algumas vantagens decisivas. Em primeiro lugar por ser considerada uma extensão (na verdade é um aprimoramento) da própria CLP, carregando consigo as características desejáveis daquele método. Em segundo lugar, e principalmente, por introduzir o conceito de compensação entre fatores. $O$ fato de 0 analista trabalhar com as diversas possibilidades de relação risco/compensação, dentro do espaço triangular de decisão, torna o método bastante flexível e, portanto, adequado às tomadas de decisão na área ambiental, em que muitas vezes a não ocorrência, em um dado local, de características favoráveis, em um ou mais fatores, pode ser compensada por um outro fator, com maior peso (influência) na análise, como apontado por Jiang e Eastman (2000) e Basnet; Apan e Raine (2001), entre outros autores que empregaram o método. 
De uma maneira geral, pode-se dizer que a capacidade de definição de áreas, com base em critérios pré-definidos pelo analista, é que torna a utilização da AMC, em ambiente SIG, uma abordagem bastante adequada a aplicações ambientais como a priorização de áreas para determinadas intervenções. Especificamente no caso de restauração florestal, Palik et al. (2000) citam que essa atividade requer uma abordagem que priorize esforços, facilitando a alocação de recursos institucionais geralmente limitados, opinião que é compartilhada por outros autores, como Snell; Monk e Dance (1995), Tim; Jain e Liao (1996), Vlahos e Herbst (2000), Randhir et al. (2001), Biswas; Sudhakar e Desai (2002), Jain e Goel (2002) e Karnib (2004). Os altos custos de implantação e manutenção de obras civis, bem como de projetos de restauração de bacias, fazem da abordagem de priorização de áreas sensíveis, ou vulneráveis, uma alternativa economicamente viável na proteção dos recursos hídricos (RANDHIR et al., 2001).

Snell; Monk e Dance (1995) citam que o processo de priorização de microbacias, em programas de conservação, deve atender a diversos critérios, como por exemplo: ter por base os ecossistemas; ser descentralizado; dar suporte à diversidade e a uma economia sustentável; ser participatório; identificar problemas prioritários; e não ser muito caro. O emprego da abordagem AMC-SIG atende a vários desses critérios. Em primeiro lugar, ela leva em conta características fisiográficas regionais (critérios da análise), portanto os próprios ecossistemas. Ainda, acomoda perfeitamente as questões de que deve ser uma abordagem participatória (definição dos fatores e de suas importâncias relativas), capaz de identificar problemas prioritários e não apresentar custo elevado.

Ainda com relação à abordagem proporcionada pela AMC em ambiente SIG, pode-se dizer que o sucesso da mesma na definição de áreas prioritárias deve-se, conforme já citado por Malczewski (2004), às capacidades próprias do SIG (aquisição, armazenamento, recuperação, manipulação e análise de dados) e às do método de tomada de decisão multicritérios, em agregar dados geográficos e preferências dos tomadores de decisão em valores unidimensionais de decisões alternativas. Essas preferências dos tomadores de decisão muitas vezes podem envolver interesses ou objetivos conflitantes, como já comentado por Eastman et al. (1995), Zhou e Civco 
(1996), Malczewski (1996) e Malczewski e Jackson (2000), e aí, mais uma vez, a AMC é capaz de acomodar a situação, justamente pela possibilidade de emprego da Técnica Participatória, na definição dos critérios e da importância relativa entre eles (pesos). 


\section{CONCLUSÕES}

A partir dos resultados obtidos neste trabalho, para a área de estudo, foi possível concluir que:

1) A Avaliação Multicritérios, em ambiente SIG, é adequada ao mapeamento de áreas prioritárias à restauração florestal em bacias hidrográficas, visando à conservação de recursos hídricos.

2) Dos métodos empregados, o da Média Ponderada Ordenada é o mais adequado à priorização de áreas à restauração florestal, dada a flexibilidade proporcionada ao analista ao acomodar o conceito de compensação entre fatores. Essa característica permite um mapeamento mais detalhado das áreas prioritárias, que são menores e em maior número que no método da Combinação Linear Ponderada, cuja aplicação é mais apropriada à determinação de grandes regiões com diferentes graus de prioridade. 


\section{REFERÊNCIAS}

ABDEL-KADER, A.F.; NASR, S.M.; EL-GAMILY, H.I.; EL-RAEY, M. Environmental sensitivity analysis of potential oil spill for Ras-Mohammed coastal zone, Egypt. Journal of Coastal Research, Tallahassee, v. 14, n. 2, p. 502-511, 1998.

ADINARAYANA, J.; RAO, K.G.; KRISHNA, N.R.; VENKATACHALAM, P.; SURI, J.K. A rule-based soil erosion model for a hilly catchment. Catena, Amsterdam, v. 37, n. 3/4, p. 309-318, 1999.

AFGAN, N.H.; CARVALHO, M.G. Multi-criteria assessment of new and renewable energy power plants. Energy, Kidlington, v. 27, n. 8, p. 739-755, 2002.

AHARONI, B.; WARD, D. A new predictive tool for identifying areas of desertification: a case study from Namibia. Desertification Control Bulletin, Nairobi, n. 31, p. 12-18, 1997.

ANDERSON, J.R.; HARDY, E.E.; ROACH, J.T.; WITMER, R.E. Sistema de classificação do uso da terra e do revestimento do solo para utilização com dados de sensores remotos. Rio de Janeiro: IBGE, 1979. 80 p.

ANDERTON, S.; LATRON, M.; GALLART, F. Sensitivity analysis and multi-response, multi-criteria evaluation of a physically based distributed model. Hydrological Processes, Hoboken, v. 16, n. 2, p. 333-353, 2002.

ARAÚJO, C.C. Aplicação de geoprocessamento na análise da favorabilidade para mineralizações de chumbo, zinco e cobre nas folhas Cerro Azul e Apiaí, Vale do Ribeira (SP e PR). 1999. 151 p. Dissertação (Mestrado em Recursos Minerais e Hidrogeologia) - Instituto de Geociências, Universidade de São Paulo, São Paulo, 1999. 
ASHTON, M.S.; GUNATILLEKE, C.V.S.; SINGHAKUMARA, B.M.P.; GUNATILEKE, I.A.U.N. Restoration pathways for rain forest in southwest Sri Lanka: a review of concepts and models. Forest Ecology and Management, Amsterdam, v. 154, n. 3, p. 409-430, 2001.

BABAN, S.M.J.; WAN-YUSOF, K. Modelling optimum sites for locating reservoirs in tropical environments. Water Resources Management, Amsterdam, v. 17, n.1, p. 1-17, 2003.

BASNET, B.B.; APAN, A.A.; RAINE, S.R. Selecting suitable sites for animal waste application using a raster GIS. Environmental Management, New York, v. 28, n. 4, p. 519-531, 2001.

BERHE, D. Experiences with the application of GIS and remote-sensing data for the development of cost-efficient and ecologically sound land-use planning, with Ethiopia presented as an example. Forstwissenschaftliches Centralblatt, Berlin, v. 111, n.1, p. 1-33, 1992.

BERTONI, J.; LOMBARDI NETO, F. Conservação do solo. Piracicaba: Livroceres, 1985. 368 p.

BISWAS, S.; SUDHAKAR, S.; DESAI, V.R. Prioritisation of subwatersheds based on morphometric analysis of drainage basin: a remote sensing and GIS approach. Photonirvachak, Dehra Dun, v. 27, n. 3, p. 155-166, 1999.

BISWAS, S.; SUDHAKAR, S.; DESAI, V.R. Remote sensing and geographic information system based approach for watershed conservation. Journal of Surveying Engineering, Reston, v. 128, n. 3, p. 108-124, 2002.

BOJORQUEZTAPIA, L.A.; AZUARA, I.; EZCURRA, E.; FLORESVILLELA, O. Identifying conservation priorities in Mexico through Geographical Information Systems and modeling. Ecological Applications, Washington, v. 5, n.1, p. 215-231, 1995. 
BORRALHO, R.; STOATE, C.; ARAUJO, M. Factors affecting the distribution of redlegged partridges Alectoris rufa in an agricultural landscape of southern Portugal. Bird Study, Thetford, v. 47, n. 3, p. 304-310, 2000.

BRITO, J.C.; GODINHO, R.; LUIS, C.; PAULO, O.S.; CRESPO, E.G. Management strategies for conservation of the lizard Lacerta schreiberi in Portugal. Biological Conservation, Kidlington, v. 89, n. 3, p. 311-319, 1999.

BRYAN, B.; HARVEY, N.; BELPERIO, T.; BOURMAN, B.. Distributed process modeling for regional assessment of coastal vulnerability to sea-level rise. Environmental Modeling and Assessment, Bussum, v. 6, n. 1, p. 57-65, 2001.

BUITRAGO, J.; RADA, M.; HERNADEZ, H.; BUITRAGO, E. A single-use site selection technique, using GIS, for aquaculture planning: choosing locations for mangrove oyster raft culture in Margarita Island, Venezuela. Environmental Management, New York, v. 35, n. 5, p. 544-556, 2005.

BURKART, M.R.; JAMES, D.E.; TOMER, M.D. Hydrologic and terrain variables to aid strategic location of riparian buffers. Journal of Soil and Water Conservation, Ankeny, v. 59, n. 5, p. 216-223, 2004.

CALIJURI, M.L.; MELLO, A.L.O.; LORENTZ, J.F. Identificação de áreas para implantação de aterros sanitários com uso de análise estratégica de decisão. Informática Pública, Belo Horizonte, v. 4, n. 2, p. 231-250, 2002.

CARVER, A.J. Fotografia aérea para planejadores do uso da terra. Brasília: MA, SNAP, SRN, CCSA, 1988. 77 p.

CENTRO DE ANÁLISE E PLANEJAMENTO AMBIENTAL. Atlas ambiental da bacia do Rio Corumbataí. Disponível em: <http://www.rc.unesp.br/igce/ceapla/atlas/>. Acesso em: 10 set. 2005. 
CEBALLOS-SILVA, A.; J. LOPEZ-BLANCO. Evaluating biophysical variables to identify suitable areas for oat in Central Mexico: a multi-criteria and GIS approach. Agriculture, Ecosystems \& Environment, Amsterdam, v. 95, n. 1, p. 371-377, 2003a.

CEBALLOS-SILVA, A.; LOPEZ-BLANCO, J. Delineation of suitable areas for crops using a Multi-Criteria Evaluation approach and land-use/cover mapping: a case study in Central Mexico. Agricultural Systems, Kidlington, v. 77, n. 2, p. 117-136, 2003b.

CHARNPRATHEEP, K.; ZHOU, Q.M.; GARNER, B. Preliminary landfill site screening using fuzzy geographical information systems. Waste Management and Research, London, v. 15, n. 2, p. 197-215, 1997.

CHEN, K.P.; BLONG, R. Towards an integrated approach to natural hazards risk assessment using GIS: With reference to bushfires. Environmental Management, New York, v. 31, n. 4, p. 546-560, 2003.

CHEN, K.P.; BLONG, R.; JACOBSON, C. MCE-RISK: integrating multicriteria evaluation and GIS for risk-decision making in natural hazards. Environmental Modelling and Software, Kidlington, v. 16, n. 4, p. 387-397, 2001.

CLAYTON, I. Sensitivity modeling data base provides GIS capabilities for non-GIS users. Earth Observation Magazine, Aurora, v. 3, n. 7, p. 25-28, 1994.

CORWIN, D.L.; LOAGUE, K.; ELLSWORTH, T.R. Advanced information technologies for assessing nonpoint source pollution in the vadose zone: conference overview. Journal of Environmental Quality, Madison, v. 28, n. 2, p. 357-365, 1999.

CURREY-GREGORY, W.; CROSBY, S. Role of GIS in watershed protection. In: ANNUAL CONFERENCE ON INTEGRATED WATER RESOURCES PLANNING FOR THE 21st. CENTURY, 22., 1995, Cambridge. Proceedings... Cambridge: ASCE, 1995. p. 340-343. 
DAHL, T.E.; YOUNG, R.D.; CALDWELL, M.C. Monitoring wetlands across large-scale ecosystems. GIS World, Philadelphia, v. 9, n. 7, p. 58-60, 1996.

DAI, F.C.; LEE, C.F.; ZHANG, X.H. GIS-based geo-environmental evaluation for urban land-use planning: a case study. Engineering Geology, Amsterdam, v. 61, n. 4, p. 257271, 2001.

DALGAARD, T.; HALBERG, N.; PORTER, J.R. A model for fossil energy use in Danish agriculture used to compare organic and conventional farming. Agriculture, Ecosystems \& Environment, Amsterdam, v. 87, n. 1, p. 51-65, 2001.

DAVOS, C.A.; LAJANO, R.P. Analytical perspectives of cooperative coastal management. Journal of Environmental Management, London, v. 62, n. 2, p. 123130, 2001.

DRAGAN, M.; FEOLI, E.; FERNETTI, M.; ZERIHUN, W. Application of a spatial decision support system (SDSS) to reduce soil erosion in northern Ethiopia. Environmental Modelling \& Software, Kidlington, v. 18, n. 10, p. 861-868, 2003.

DUTTA, D.; DAS, S.N.; SHARMA, J.R.; KUDRAT, M.; MARCHANDA, M.L. Prioritization of watersheds for perspective land use planning using remote sensing and geographic information system. Annals of Arid Zone, Jodhpur, v. 36, n. 2, p. 103-114, 1997.

EASTMAN, J.R. Decision support: decision strategy analysis. In: Idrisi 32 release 2: guide to GIS and image processing. Worcester: Clark University, Clark Labs, 2001. v. 2, p. 1-22.

EASTMAN, J.R. IDRISI Kilimanjaro: guide to GIS and image processing. Worcester: Clark University, Clark Labs, 2003. 306 p. 
EASTMAN, J.R.; JIANG, H. Fuzzy measures in multi-criteria evaluation. In: INTERNATIONAL SYMPOSIUM ON SPATIAL ACCURACY ASSESSMENT IN NATURAL RESOURCES AND ENVIRONMENTAL STUDIES, 2., 1996, Fort Collins. Proceedings... Fort Collins: USDA Forest Service, 1996. p. 527-534.

EASTMAN, J.R.; KYEM, P.A.K.; TOLEDANO, J. GIS and decision making. Genebra: UNITAR, 1993. 112 p. (Explorations in Geographic Information Systems Technology).

EASTMAN, J.R.; JIN, W.G.; KYEM, P.A.K.; TOLEDANO, J. Raster procedures for multicriteria/multi-objective decisions. Photogrammetric Engineering and Remote Sensing, Bethesda, v. 61, n. 5, p. 539-547, 1995.

EMPRESA BRASILEIRA DE PESQUISA AGROPECUÁRIA. Sistema brasileiro de classificação de solos. Brasília: Centro Nacional de Pesquisa de Solos, 1999. 412 p.

ESPELTA, J.M.; RETANA, J.; HABROUK, A. An economic and ecological multi-criteria evaluation of reforestation methods to recover burned Pinus nigra forests in NE Spain. Forest Ecology and Management, Amsterdam, v. 180, n. 1/3, p. 185-198, 2003.

FAO. Watershed management field manual: road design and construction in sensitive watersheds. Rome: FAO Consultation Guide 13/5, 1989. 196 p.

FEIST, B.E.; STEEL, E.A.; PESS, G.R.; BILBY, R.E. The influence of scale on salmon habitat restoration priorities. Animal Conservation, New York, v. 6, n. 3, p. 271-282, 2003.

FENG, S.; XU, L.D. Decision support for fuzzy comprehensive evaluation of urban development. Fuzzy Sets and Systems, Amsterdam, v. 105, n. 1, p. 1-12, 1999.

FERRAZ, S.F.B.; VETTORAZZI, C.A. Mapeamento de risco de incêndios florestais por meio de sistema de informações geográficas (SIG). Scientia Forestalis, Piracicaba, n. 53, p. 39-48, 1998. 
FERRAZ, S.F.B.; VETTORAZZI, C.A. Identificação de áreas para a recomposição florestal com base em princípios de Ecologia da Paisagem. Revista Árvore, Viçosa, v. 27 , n. 4 , p. 575-583, 2003.

FRUTUOSO, N.G.; VETTORAZZI, C.A.; COUTO, H.T.Z. Emprego de um sistema de informações geográficas na análise da distribuição do veado-campeiro (Ozotoceros bezoarticus), no Parque Nacional das Emas, Goiás. In: CONGRESSO BRASILEIRO DE CONSERVAÇÃO E MANEJO DA BIODIVERSIDADE, 1., 1999, Ribeirão Preto. Resumos... Rio Claro: UNESP, CEA, CODERP, 1999. 1 CD-ROM.

GARCIA, L.B.R. Ocupação e desenvolvimento econômico da bacia do Corumbataí: séculos XVIII a XX: atlas ambiental da bacia do Rio Corumbataí. Disponível em: <http://www.rc.unesp.br/igce/ceapla>. Acesso em: 16 maio 2005.

GERHARD, P. Comunidades de peixes de riachos em função da paisagem da bacia do Rio Corumbataí, Estado de São Paulo. 2005. 241 p. Tese (Doutorado em Ecologia de Agroecossistemas) - Escola Superior de Agricultura "Luiz de Queiroz", Universidade de São Paulo, Piracicaba, 2005.

GOMES, E.G.; LINS, M.P.E. Integrating Geographical Information Systems and multicriteria methods: a case study. Annals of Operations Research, Dordrecht, v. 116, n. 1/4, p. 243-269, 2002.

GREEN, K.; BERNATH, S.; LACKLEY, L.; BRUNENGO, M.; SMITH, S. Analyzing the cumulative effects of forest practices: where do we start? Geo Info Systems, Norman, v. 3, n. 2, p. 31-41, 1993.

GUMBRICHT, T.; McCARTHY, J.; MAHLANDER, C. Digital interpretation and management of land cover: a case study of Cyprus. Ecological Engineering, Amsterdam, v. 6, n. 4, p. 273-279, 1996.

HARRINGTON, C.A. Forests planted for ecosystem restoration or conservation. New Forests, Dordrecht, v. 17, n. 1/3, p. 175-190, 1999. 
HAWKS, M.M.; STANOVICK, J.S.; CALDWELL, M.L. Demonstration of GIS capabilities for fisheries management decisions: analysis of acquisition potential within the Meramec river basin. Environmental Management, New York, v. 26, n. 1, p. 25-34, 2000.

HENDRICKX, G.; ROCQUE, S. de la; REID, R.; WINT, W. Spatial trypanosomiasis management: from data layers to decision making. Trends in Parasitology, Kidlington, v. 17, n. 1, p. 35-41, 2001.

HICKEY, R.; JANKOWSKI, P. GIS and environmental decision-making to aid smelter reclamation planning. Environment and Planning, London, v. 29, n. 1, p. 5-19, 1997.

HILL, M.J.; DONALD, G.E.; VICKERY, P.J.; FURNIVAL, E.P. Integration of satellite remote sensing, simple bioclimatic models and GIS for assessment of pastoral development for a commercial grazing enterprise. Australian Journal of Experimental Agriculture, Collingwood, v. 36, n. 3, p. 309-321, 1996.

HOCTOR, T.S.; CARR, M.H.; ZWICK, P.D. Identifying a linked reserve system using a regional landscape approach: the Florida ecological network. Conservation Biology, Malden, v. 14, n. 4, p. 984-1000, 2000.

INSTITUTO DE PESQUISAS E ESTUDOS FLORESTAIS. Conservação dos recursos hídricos por meio da recuperação e da conservação da cobertura florestal da bacia do Rio Corumbataí. Piracicaba, 2001. 301 p. (Plano Diretor).

JAIN, A.; RAVAN, S.A.; SINGH, R.K.; DAS, K.K.; ROY, P.S. Forest fire risk modeling using remote sensing and geographic information system. Current Science, Bangalore, v. 70, n. 10, p. 928-933, 1996.

JAIN, S.K.; GOEL, M.K. Assessing the vulnerability to soil erosion of the Ukai Dam catchments using remote sensing and GIS. Hydrological Sciences Journal, Wallingford, v. 47, n. 1, p. 31-40, 2002. 
JANKOWSKI, P. Integrating geographical information systems and multiple criteria decision-making methods. International Journal of Geographical Information Systems, Abingdon, v. 9, n. 3, p. 251-273, 1995.

JANKOWSKI, P.; ANDRIENKO, N.; ANDRIENKO, G. Map-centred exploratory approach to multiple criteria spatial decision making. International Journal of Geographical Information Science, Abingdon, v. 15, n. 2, p. 101-127, 2001.

JARVIS, A.M.; ROBERTSON, A. Predicting population sizes and priority conservation areas for ten endemic Namibian bird species. Biological Conservation, Kidlington, v. 88, n. 1, p. 121-131, 1999.

JIANG, H.; EASTMAN, J.R. Application of fuzzy measures in multi-criteria evaluation in GIS. International Journal of Geographical Information Science, Abingdon, v. 14, n. 2, p. 173-184, 2000.

JONES, K.B.; NEALE, A.C.; WADE, T.G.; WICKHAM, J.D.; CROSS, C.L.; EDMONDS, C.M.; LOVELAND, T.R.; NASH, M.S.; RIITTERS, K.H.; SMITH, E.R. The consequences of landscape change on ecological resources: an assessment of the United States MidAtlantic region, 1973-1993. Ecosystem Health, Malden, v. 7, n. 4, p. 229-242, 2001.

KANGAS, J.; TORE, R.; LESKINEN, P.; MEHTÄTALO, L. Improving the quality of landscape ecological forest planning by utilising advanced decision-support tools. Forest Ecology and Management, Amsterdam, v. 132, p. 157-171, 2000.

KARNIB, A. An approach to elaborate priority preorders of water resources projects based on multi-criteria evaluation and fuzzy set analysis. Water Resources Management, Dordrecht, v. 18, n. 1, p. 13-33, 2004.

KLUNGBOONKRONG, P.; TAYLOR, M.A.P. Microcomputer-based system for multicriteria environmental impacts evaluation of urban road networks. Computer, Environment and Urban Systems, Amsterdam, v. 22, n. 5, p. 425-446, 1998. 
KOFFLER, N.F. Uso das terras da bacia do rio Corumbataí em 1990. Geografia, Rio Claro, v. 18, n. 1, p. 135-150, 1993.

KOFFLER, N.F. Carta de declividade da bacia do rio Corumbataí para análise digital (SIG). Geografia, Rio Claro, v. 19, n. 2, p. 167-182, 1994.

KONTOS, T.D.; KOMILIS, D.R.; HALVADAKIS, C.P. Siting MSW landfills on Lesvos Island with a GIS-based methodology. Waste Management \& Research, London, v. 21, n. 3, p. 262-277, 2003.

KUDRAT, M.; TIWARI, A.K.; SAHA, S.K. Modelling sediment yield for prioritization of sub-watersheds using remote sensing and GIS techniques. Geocarto International, Hong Kong, v. 12, n. 2, p. 31-37, 1997.

LANDIS, J.R.; KOCH, G.G. The measurement of observer agreement for categorical data. Biometrics, Arlington, v. 33, p. 159-174, 1977.

LAPLANA, R.; BRUNSTEIN, D. Les erosion eolienne et regressive dans le bassin versant de la Leyre. Bulletin de I'Institute de Geologie du Bassin d'Aquitane, Bordeaux, n. 51/52, p. 21-29, 1992.

LATHROP JUNIOR, R.G.; BOGNAR, J.A. Applying GIS and landscape ecological principles to evaluate land conservation alternatives. Landscape and Urban Planning, Amsterdam, v. 41, n. 1, p. 27-41, 1998.

LEPSCH, I.F. (Coord.). Manual para levantamento utilitário do meio físico e classificação de terras no sistema de capacidade de uso. Campinas: Sociedade Brasileira de Ciência do Solo, 1983. 175 p.

LI, X.; YEH, A.G.O. Zoning land for agricultural protection by the integration of remote sensing, GIS, and cellular automata. Photogrammetric Engineering and Remote Sensing, Bethesda, v. 67, n. 4, p. 471-477, 2001. 
LI, X.; YEH, A.G.O. Urban simulation using principal components analysis and cellular automata for land-use planning. Photogrammetric Engineering and Remote Sensing, Bethesda, v. 68, n. 4, p. 341-351, 2002.

LIMA, W.P. Floresta natural protege e estabiliza recursos hídricos. Visão Agrícola, Piracicaba, ano 2, n. 4, p. 30-33, 2005.

LLEWELLYN, D.W.; SHAFFER, G.P.; CRAIG, N.J.; CREASMAN, L.; PASHLEY, D.; SWAN, M.; BROWN, C. A decision-support system for prioritizing restoration sites on the Mississippi River Alluvial Plain. Conservation Biology, Malden, v. 10, n. 5, p. 14461455, 1996.

LOMBARDI NETO, F.; MOLDENHAUER, W.C. Erosividade da chuva: sua distribuição e relação com perdas de solo em Campinas, SP. In: ENCONTRO NACIONAL DE PESQUISA SOBRE CONSERVAÇÃO DO SOLO, 3., 1980, Recife. Anais... Recife: SBCS, 1980. p. 13.

LURTZ, P.W.W.; GEDDES, N.; LLOYD, A.J.; SHIRLEY, M.D.E.; RUSHTON, S.P.; BURLTON, B. Planning a red squirrel conservation area: using a spatially explicit population dynamics model to predict the impact of felling and forest design plans. Forestry, Edinburgh, v. 76, n. 1, p. 95-108, 2003.

MACHADO, R.E.; VETTORAZZI, C.A.; XAVIER, A.C. Simulação de cenários alternativos de uso da terra em uma microbacia, utilizando técnicas de modelagem e geoprocessamento. Revista Brasileira de Ciência do Solo, Viçosa, v. 27, n. 4, p. 727733, 2003.

MALCZEWSKI, J. A GIS-based approach to multiple criteria group decision-making. International Journal of Geographical Information Systems, Abingdon, v. 10, n. 8, p. 955-971, 1996.

MALCZEWSKI, J. GIS and multicriteria decision analysis. New York: John Wiley, 1999. $362 \mathrm{p}$. 
MALCZEWSKI, J. On the use of Weighted Linear Combination method in GIS: Common and best practice approaches. Transactions in GIS, Oxford, v. 4, n. 1, p. 5-22, 2000.

MALCZEWSKI, J. GIS-based land-use suitability analysis: a critical overview. Progress in Planning, New York, n. 62, p. 3-65, 2004.

MALCZEWSKI, J.; JACKSON, M. Multicriteria spatial allocation of educational resources: an overview. Socio-Economic Planning Sciences, New York, v. 34, p. 219235, 2000.

MALCZEWSKI, J.; CHAPMAN, T.; FLEGEL, C.; WALTERS, D.; SHRUBSOLE, D.; HEALY, M.A. GIS - multicriteria evaluation with Ordered Weighted Averaging (OWA): case study of developing watershed management strategies. Environment and Planning A, London, v. 35, n. 10, p. 1769-1784, 2003.

MAZZETTO, F.; BONERA, R. MEACROS: a tool for multi-criteria evaluation of alternative cropping systems. European Journal of Agronomy, Amsterdam, v. 18, n. 3/4, p. 379-387, 2003.

McKINSEY, D. Priority ranking for prescribed burning in the Cuymaca Rancho State Park using a Geographic Information System. GIS/LIS'88. In: INTERNATIONAL CONFERENCE, 3., 1988, San Antonio. Proceedings... San Antonio: ASPRS, ACMS, 1988. v. 2, p. 961-970.

MENNELLA, V.G.G.; BORGHI, P.; MARCELLARI, E.; PORCEDDU, P.R. Territorial vulnerability evaluation in Tiber watershed. Environmental Monitoring and Assessment, Dordrecht, v. 41, n. 2, p. 183-200, 1996.

MERWE, J.H. van der; LOHRENTZ, G. Demarcating coastal vegetation buffers with multicriteria evaluation and GIS at Saldanha Bay, South Africa. Ambio, Stockholm, v. 30, n. 2, p. 89-95, 2001. 
MILLER, R.C.; GUERTIN, D.P.; HEILMAN, P. Information technology in watershed management decision making. Journal of the American Water Resources Association, Middleburg, v. 40, n. 2, p. 347-357, 2004.

MOE, K.A.; SKEIE, G.M.; BRUDE, O.W.; LOVAS, C.M.; NEDREBO, M.; WESLAWSKI, J.M. The Svalbard intertidal zone: a concept for the use of GIS in applied oil sensitivity, vulnerability and impact analyses. Spill Science \& Technology Bulletin, Kidlington, v. 6 , n. 2, p. 187-206, 2000.

MORETTI, L.R. A importância da bacia do Corumbataí para a produção de água. In: SIMPÓSIO SOBRE RECUPERAÇÃO FLORESTAL NA BACIA DO RIO CORUMBATAÍ, 3., 2000. Piracicaba. Anais... Piracicaba: IPEF, 2000. Não paginado.

NIEMUTH, N.D. Identifying landscapes for greater prairie chicken translocation using habitat models and GIS: a case study. Wildlife Society Bulletin, Bethesda, v. 31, n. 1, p. 145-155, 2003.

NIGHMAN, D.M.; ARNOLD, L.; McKEW, S. The use of a natural resource analysis to create a comprehensive land use plan and community guide for watershed protection in Carlisle Township, Lorain County, Ohio. Ohio Journal of Science, Columbus, v. 99, n. 1, p. A-31, 1999.

O'BRIEN-WHITE, S.; THOMASON, C.S. Evaluating fish habitat in a South Carolina watershed using GIS. Charleston: NCASI, 1999. p. 391. (Technical Bulletin, 781).

OLIVEIRA, J.B. Solos da folha de Piracicaba. Campinas: Instituto Agronômico, 1999. 173 p. (IAC. Boletim Científico, 48).

OLIVEIRA, J.B.; PRADO, H.; ALMEIDA, C.L.F. Levantamento pedológico semidetalhado do Estado de São Paulo: quadrícula de São Carlos. Campinas: Convênio Embrapa - Secretaria de Agricultura e Abastecimento do Estado de São Paulo; Coordenadoria da Pesquisa Agropecuária; Instituto Agronômico, Divisão de Solos, Seção de Pedologia, 1981a. 1 mapa. Escala 1:100.000. 
OLIVEIRA, J.B.; MENK, J.R.F.; BARBIERI, J.L.; ROTTA, C.L.; TREMOCOLDI, W. Levantamento pedológico semi-detalhado do Estado de São Paulo: quadrícula de Araras. Convênio Embrapa - Secretaria de Agricultura e Abastecimento do Estado de São Paulo; Coordenadoria da Pesquisa Agropecuária; Instituto Agronômico, Divisão de Solos, Seções de Pedologia e Fotointerpretação, 1981b. 1 mapa. Escala 1:100.000.

OLIVEIRA, J.B.; PRADO, H.; BEJAR, O.I.G.; OLIVEIRA, E.R.; LONGOBARDI, R.C.; ASSIS, E.A. Carta pedológica semi-detalhada do Estado de São Paulo: quadrícula de Piracicaba. São Paulo: Secretaria de Agricultura e Abastecimento do Estado de São Paulo; Coordenadoria da Pesquisa Agropecuária; Instituto Agronômico; Secretaria de Economia e Planejamento; Coordenadoria de Ação Regional; Instituto Geográfico e Cartográfico, 1989. 1 mapa. Escala 1:100.000.

OSTWALD, M. GIS-based support tool system for decision-making regarding local forest protection: illustrations from Orissa, India. Environmental Management, New York, v. 30, n. 1, p. 35-45, 2002.

PADMAVATHY, A.S.; RAJ, K.G.; YOGARAJAN, N.; THANGAVEL, P.; CHANDRASEKHAR, M.G. Checkdam site selection using GIS approach. Advances in Space Research, Kidlington, v. 13, n. 11, p. 123-127, 1993.

PALIK, B.J.; GOEBEL, P.C.; KIRKMAN, L.K.; WEST, L. Using landscape hierarchies to guide restoration of disturbed ecosystems. Ecological Applications, Washington, v. 10, n. 1, p. 189-202, 2000.

PALMA-SILVA, G.M. Diagnóstico ambiental: qualidade de água e índice de depuração do Rio Corumbataí, SP. 1999. 155 p. Dissertação (Mestrado em Geociências e Meio Ambiente) - Centro de Estudos Ambientais, Universidade Estadual Paulista "Júlio de Mesquita Filho", Rio Claro, 1999.

PANIGRAHY, S.; CHAKRABORTY, M. An integrated approach for potato crop intensification using temporal remote sensing data. ISPRS Journal of Photogrammetry and Remote Sensing, Amsterdam, v. 53, n. 1, p. 54-60, 1998. 
PANOU, K.D.; SOFIANOS, A.I. A fuzzy multicriteria evaluation system for the assessment of tunnels vis-a-vis surface roads: theoretical aspects: part I. Tunneling and Underground Space Technology, Kidlington, v. 17, n. 2, p. 195-207, 2002a.

PANOU, K.D.; SOFIANOS, A.I. A fuzzy multicriteria evaluation system for the assessment of tunnels vis-a-vis surface roads: the WPMA case: part II. Tunneling and Underground Space Technology, Kidlington, v. 17, n. 2, p. 209-219, 2002b.

PEREIRA, J.M.C.; DUCKSTEIN, L. A multiple criteria decision-making approach to GISbased land suitability evaluation. International Journal of Geographical Information Systems, London, v. 7, n. 5, p. 407-424, 1993.

PERRY, C.D.; VELLIDIS, G.; LOWRANCE, R.; THOMAS, D.L. Watershed-scale water quality impacts of riparian forest management. Journal of Water Resources Planning and Management, New York, v. 125, n. 3, p. 117-125, 1999.

PETTIT, C.; PULLAR, D. An integrated planning tool based upon multiple criteria evaluation of spatial information. Computers, Environment and Urban Systems, London, v. 23, p. 339-357, 1999.

PLAMONDON, A.P.; RUIZ, R.A.; MORALES, C.F.; GONZALEZ, M.C. Influence of protection forest on soil and water conservation (Oxapampa, Peru). Forest Ecology and Management, Amsterdam, v. 38, n. 3/4, p. 227-238, 1991.

PROJETO PIRACENA. Banco de dados "Geoprocessamento". Disponível em: <http://www.cena.usp.br/piracena>. Acesso em: 15 ago. 2000.

RAMESH, B.R.; MENON, S.; BAWA, K.S. A vegetation based approach to biodiversity gap analysis in the Agastyamalai region, Western Ghats, India. Ambio, Stockholm, v. 26, n. 8, p. 529-536, 1997. 
RANDHIR, T.O.; O'CONNOR, R.; PENNER, P.R.; GOODWIN, D.W. A watershed-based land prioritization model for water supply protection. Forest Ecology and Management, Amsterdam, v. 143, n. 1/3, p. 47-56, 2001.

RICHARDSON, M.S.; GATTI, R.C. Prioritizing wetland restoration activity within a Wisconsin watershed using GIS modeling. Journal of Soil and Water Conservation, Ankeny, v. 54, n. 3, p. 537-542, 1999.

ROBINSON, T.P. Geographic information systems and the selection of priority areas for control of tsetse-transmitted trypanosomiasis in Africa. Parasitology Today, Kidlington, v. 14, n. 11 , p. 457-461, 1998.

ROBINSON, T.P.; HARRIS, R.S.; HOPKINS, J.S.; WILLIAMS, B.G. An example of decision support for trypanosomiasis control using a geographical information system in eastern Zambia. International Journal of Geographical Information Science, Abingdon, v. 16, n. 4, p. 345-360, 2002.

RODRIGUES, R.R. A vegetação de Piracicaba e municípios de entorno. Circular Técnica IPEF, Piracicaba, v. 189, p. 1-18, 1999.

ROOY, P.T.J.C. van; SLUIS, J.W. van; TOLKAMP, H.H. PRIMAVERA: Decision support system for integral water management. European Water Pollution Control, New York, v. 5, n. 1, p. 6-9, 1995.

ROY, P.S.; TOMAR, S. Biodiversity characterization at landscape level using geospatial modelling technique. Biological Conservation, Kidlington, v. 95, n. 1, p. 95-109, 2000.

SAATY, T.L. A scaling method for priorities in hierarchical structures. Journal of Mathematical Psychology, San Diego, v. 15, p. 234-281, 1977.

SAATY, T.L. The analytic hierarchic process. New York: McGraw-Hill, 1980. 287 p. 
SADEK, S.; BEDRAN, M.; KAYSI, I. GIS platform for multicriteria evaluation of rout alignments. Journal of Transportation Engineering, New York, v. 125, n. 2, p. 144151, 1999.

SALAM, M.A.; KHATUN, N.A.; ALI, M.M. Carp farming potential in Barhatta Upazilla, Bangladesh: a GIS methodological perspective. Aquaculture, Amsterdam, v. 245, n. 14, p. 75-87, 2005.

SALATI, E. Diagnóstico ambiental sintético e qualidade da água como subsídio para o planejamento regional integrado da bacia hidrográfica do rio Corumbataí (SP). 1996. 199 p. Tese (Doutorado em Ciências da Engenharia Ambiental) - Escola de Engenharia de São Carlos, Universidade de São Paulo, São Carlos, 1996.

SCOTT, M.C.; HELFMAN, G.S.; McTAMMANY, M.E.; BENFIELD, E.F.; BOLSTAD, P.V. Multiscale influences on physical and chemical stream conditions across Blue Ridge landscapes. Journal of the American Water Resources Association, Middleburg, v. 38, n. 5 , p. 1379-1392, 2002

SENTELHAS, P.C.; MARIN, F.R.; PEREIRA, A.R.; ANGELOCCI, L.R.; VILLA NOVA, N.A.; BARBIERI, V. Análise dos dados climáticos e do balanço hídrico climatológico de Piracicaba. Piracicaba: ESALQ, DFM, 1998. 81 p.

SMITH, A.P.; HORNING, N.; MOORE, D. Regional biodiversity planning and lemur conservation with GIS in western Madagascar. Conservation Biology, Malden, v. 11, n. 2, p. 498-512, 1997.

SNELL, E.; MONK, K.; DANCE, K. Targeted ecological planning of the Ausable-Bayfield Conservation Authority watershed. In: ANNUAL MEETING OF THE SOIL AND WATER CONSERVATION SOCIETY, 50., 1995, Des Moines. Proceedings... Des Moines: Soil and Water Conservation Society, 1995. p. 5. 
SOUZA, F.M. de; BATISTA, J.L.F. Restoration of seasonal semideciduous forests in Brazil: influence of age and restoration design on forest structure. Forest Ecology and Management, Amsterdam, v. 191, p. 185-200, 2004.

STOMS, D.M.; McDONALD, J.M.; DAVIS, F.W. Fuzzy assessment of land suitability for scientific research reserves. Environmental Management, New York, v. 29, n. 4, p. 545-558, 2002.

STOORVOGEL, J.J.; ANTLE, J.M. Regional land use analysis: the development of operational tools. Agricultural Systems, Kidlington, v. 70, n. 2/3, p. 623-640, 2001.

STORE, R.; KANGAS, J. Integrating spatial multi-criteria evaluation and expert knowledge for GIS-based habitat suitability modelling. Landscape and Urban Planning, Amsterdam, v. 55, n. 2, p. 79-93, 2001.

SUBRA, W.; WATERS, J. Non point source pollution. In: INTERNATIONAL GEOSCIENCE AND REMOTE SENSING SYMPOSIUM, 1996, Piscataway. Proceedings... Piscataway: IEEE, 1996. v. 4, p. 2231-2233.

SWEENEY, B.W.; CZAPKA, S.J.; YERKES, T. Riparian forest restoration: increasing success by reducing plant competition and herbivory. Restoration Ecology, Malden, v. 10, n. 2, p. 392-400, 2002.

TAGLIANI, C.R.A. Técnica para avaliação da vulnerabilidade ambiental de ambientes costeiros utilizando um sistema geográfico de informações. Curitiba: FatorGIS, 2002. 8 p. Disponível em: <http://www.fatorgis.com.br>. Acesso em: 20 set. 2005.

TEMESGEN, B.; MOHAMMED, M.U.; KORME, T. Natural hazard assessment using GIS and remote sensing methods, with particular reference to the landslides in the Wondogenet area, Ethiopia. Physics and Chemistry of the Earth. Part C - Solar, Terrestrial and Planetary Science, Kidlington, v. 26, n. 9, p. 665-675, 2001. 
TIM, U.S.; JAIN, D.; LIAO, H.H. Interactive modeling of ground-water vulnerability within a geographic information system environment. Ground Water, Westerville, v. 34, n. 4, p. 618-627, 1996.

TROPPMAIR, H. Características naturais e sócio-econômicas. In: SEMANA DE DEBATES SOBRE RECURSOS HÍDRICOS E MEIO AMBIENTE, 1992, Piracicaba. Atas... Piracicaba: Consórcio Intermunicipal das Bacias dos Rios Piracicaba, Capivari e Jundiaí; DAEE; FUNDAP, 1992. p. 161-163.

TROPPMAIR, H.; MACHADO, M.L.A. Variação da estrutura da mata de galeria na bacia do rio Corumbataí (SP) em relação a água do solo, tipo de margem e do traçado do rio. Biogeografia, São Paulo, n. 8, p. 1-28, 1974.

TURNER, R.K.; BERGH, J.C.J.M. van den; SODERQVIST, T.; BARENDREGT, A.; STRAATEN; J. van der; MALTBY, E. Ecological-economic analysis of wetlands: scientific integration for management and policy. Ecological Economics, Amsterdam, v. 35, n. 1, p. 7-23, 2000.

VALENTE, R.O.A. Definição de áreas prioritárias para conservação e preservação florestal por meio da abordagem multicriterial em ambiente SIG. 2005. 121 p. Tese (Doutorado em Recursos Florestais) - Escola Superior de Agricultura "Luiz de Queiroz", Universidade de São Paulo, Piracicaba, 2005.

VALENTE, R.O.A.; VETTORAZZI, C.A. Análise da estrutura da paisagem na bacia do Rio Corumbataí, SP. Scientia Forestalis, Piracicaba, n. 62, p. 114-129, 2002.

VALENTE, R.O.A.; VETTORAZZI, C.A. Mapeamento do uso e cobertura do solo da bacia do Rio Corumbataí, SP. Circular Técnica IPEF, Piracicaba, n. 196, p. 1-9, 2003.

VALENTE, R.O.A.; VETTORAZZI, C.A. A abordagem multicriterial na definição de áreas prioritárias para conservação e preservação florestal. In: SIMPÓSIO BRASILEIRO DE SENSORIAMENTO REMOTO, 12., 2005, Goiânia. Anais... Goiânia: INPE, 2005, 1 CDROM. 
VARMA, V.K.; FERGUSON, I.; WILD, I. Decision support system for the sustainable forest management. Forest Ecology and Management, Amsterdam, v. 128, n. 1-2, p. 49-55, 2000.

VERÍSSIMO, A.; SOUZA JÚNIOR, C.; STONE, S.; UHL, C. Zoning of timber extraction in the Brazilian Amazon. Conservation Biology, Malden, v. 12, n. 1, p. 128-136, 1998.

VERÍSSIMO, A.; COCHRANE, M.A.; SOUZA, C.; SALOMÃO, R. Priority areas for establishing national forests in the Brazilian Amazon. Conservation Ecology, Waterloo, v. 6, n. 1, 2002. Disponível em: <http://www.consecol.org/vol6/iss1/art4>. Acesso em: 23 mar. 2005.

VETTORAZZI, C.A.; VALENTE, R.O.A.; BALLESTER, M.V.R. Forest fire hazard mapping in a GIS environment for a river basin in the State of São Paulo, Brazil. In: INTERNATIONAL CONFERENCE ON GEOSPATIAL INFORMATION IN AGRICULTURE AND FORESTRY, 2., 2000, Lake Buena Vista. Proceedings... Ann Arbor: ERIM International, 2000. v. 1, p. 609-616.

VIADANNA, A.G. Análise de qualidade hídrica do alto e médio Corumbataí (SP) pela aplicação de bioindicadores. 1985. 112 p. Dissertação (Mestrado em Geociências e Meio Ambiente) - Instituto de Geociências, Universidade Estadual Paulista "Júlio de Mesquita Filho", Rio Claro, 1985.

VILLA, F.; CERONI, M.; MAZZA, A. A GIS-based method for multi-objective evaluation of park vegetation. Landscape and Urban Planning, Amsterdam, v. 35, n. 4, p. 203212, 1996.

VLAHOS, N.; HERBST, J. Prioritizing watershed land for conservation: a case study in the Hammonasset Watershed, Connecticut. Journal of the New England Water Works Association, Boston, v. 114, n. 1, p. 10-25, 2000. 
VOOGD, H. Multicriteria evaluation for urban and regional planning. London: Pion, 1983. $370 \mathrm{p}$.

WANG, D.H.; MEDLEY, K.E. Land use model for carbon conservation across a Midwestern USA landscape. Landscape and Urban Planning, Amsterdam, v. 69, n. 4, p. 451-465, 2004.

WEBB, A.D.; BACON, P.J. Using GIS for catchment management and freshwater salmon fisheries in Scotland: the DeeCAMP project. Journal of Environmental Management, London, v. 55, n. 2, p. 127-143, 1999.

WILSON, D.J.; DROSTE, R.L. Design considerations for watershed management decision support systems. Water Quality Research Journal of Canada, Gloucester, v. 35 , n. 2, p. 163-188, 2000.

WRIGHT, R.G.; TANIMOTO, P.D. Using GIS to prioritize land conservation actions: Integrating factors of habitat diversity, land ownership, and development risk. Natural Areas Journal, Rockford, v. 18, n. 1, p. 38-44, 1998.

YAGER, R.R. On Ordered Weighted Averaging aggregation operators in multicriteria decision-making. IEEE Transactions on Systems Man and Cybernetics, New York, v. 8, n. 1, p. 183-190, 1988.

YIN, Y.Y. Flood management and sustainable development of water resources: the case of Great Lake Basin. Water International, Carbondale, v. 26, n. 2, p. 197-205, 2001.

ZHOU, J.; CIVCO, D.L. Using genetic learning neural networks for spatial decision making in GIS. Photogrammetric Engineering and Remote Sensing, Bethesda, v. 62, n. 11, p. 1287-1295, 1996. 